Check for updates

Cite this: RSC Adv., 2020, 10, 44408

Received 24th October 2020

Accepted 20th November 2020

DOI: $10.1039 / \mathrm{d}$ Ora09088c

rsc.li/rsc-advances

\section{A click-based modular approach to introduction of peroxides onto molecules and nanostructures $\uparrow$}

\begin{abstract}
Alissa Horn and Patrick H. Dussault*
Copper-promoted azide/alkyne cycloadditions (CUAAC) are explored as a tool for modular introduction of peroxides onto molecules and nanomaterials. Dialkyl peroxide-substituted alkynes undergo $\mathrm{Cu}(\mathrm{l})$ promoted reaction with azides in either organic or biphasic media to furnish peroxide-substituted 1,2,3triazoles. Heterolytic fragmentation of the peroxide to an aldehyde, a side reaction that appears to be related to the formation of the triazole, can be suppressed by use of excess alkyne, the presence of triethylsilane, or by use of iodoalkyne substrates. Complementary reactions of simple alkynes with azidosubstituted peroxides are much less efficient. Click reactions of alkynyl peroxyacetals are also reported; reductive fragmentation can be minimized by increasing the distance between the peroxyacetal and the alkyne. The strategy enables modular introduction of dialkyl peroxides and peroxyacetals onto gold nanoparticles, the first such process to be reported.
\end{abstract}

\section{Introduction}

Organic peroxides are capable of a wide range of reaction pathways, ${ }^{1}$ and have been applied as oxidants, ${ }^{2}$ radical initiators, ${ }^{3}$ pharmacophores, ${ }^{4}$ enzyme inhibitors, ${ }^{5}$ and synthons for electrophilic transfer of alkoxide. ${ }^{6}$ Peroxides are also of interest as intermediates and products of oxidative degradation and sources of reactive oxygen species. ${ }^{7}$ This rich chemistry contrasts with the limited number of reports describing reactivity or application of peroxides at surfaces. ${ }^{8}$ This discontinuity cannot be completely attributed to concerns for stability or safety. Peroxides are compatible with a surprising variety of synthetic transformations, ${ }^{9}$ and many peroxides may be safely employed by following established precautions. ${ }^{10} \mathrm{~A}$ more significant barrier to broader use of peroxides is the lack of effective methods for their modular introduction under mild conditions.

"Click chemistry", a family of strategies based upon rapid and specific pairwise reactions of matched functional groups, has become an indispensable tool for modular approaches to molecules, supramolecules, and functionalized surfaces and nanoparticles. ${ }^{11}$ The most widely applied of these transformations, is the copper-assisted azide/alkyne cycloaddition (CuAAC), now a workhorse reaction for ligation and modification of molecules and supramolecules. ${ }^{12} \mathrm{CuAAC}$ chemistry has been employed to generate derivatives of the peroxide antimalarial artemisinin, ${ }^{13}$ and we became interested in the potential for modular introduction of peroxides via click reactions. We

Department of Chemistry, University of Nebraska-Lincoln, Lincoln, NE 68588-0304, USA.E-mail: pdussault1@unl.edu

$\dagger$ Electronic supplementary information (ESI) available: ${ }^{1} \mathrm{H}$ and ${ }^{13} \mathrm{C}$ NMR spectra of molecules, as well as ${ }^{1} \mathrm{H}$, IR, and XPS characterization of functionalized $\mathrm{Au}$ nanoparticles (100 pages). See DOI: 10.1039/d0ra09088c now describe explorations of the scope of CuAAC chemistry reaction in terms of the nature of the peroxide group, whether the peroxide is linked to the alkyne or azide partner, the distance of the peroxide from the reaction center, and the influence of reaction conditions. The fragmentation of the peroxides observed in some of the click reactions of peroxyacetals demonstrates a potential for controlled generation of reactive oxygen species. We also demonstrate successful application of these ligations to modular introduction of peroxides on the surface of functionalized Au nanoparticles (AuNP),

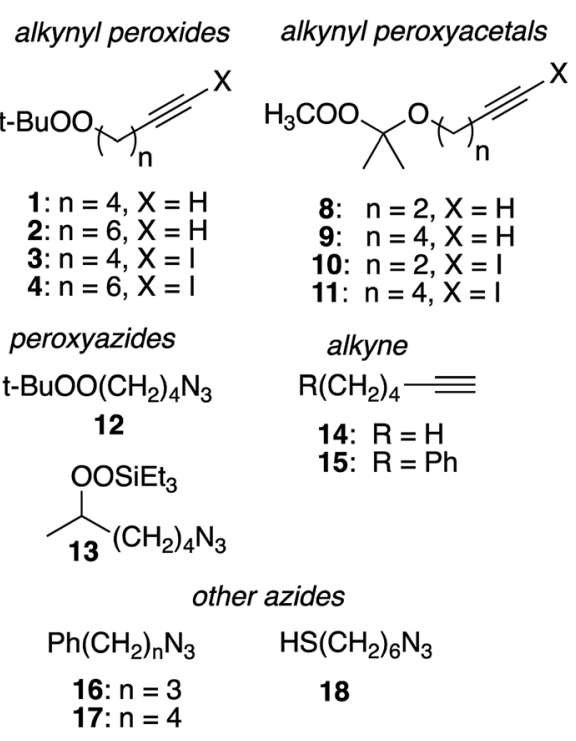

Fig. 1 Substrates used for CuAAC chemistry studies. 


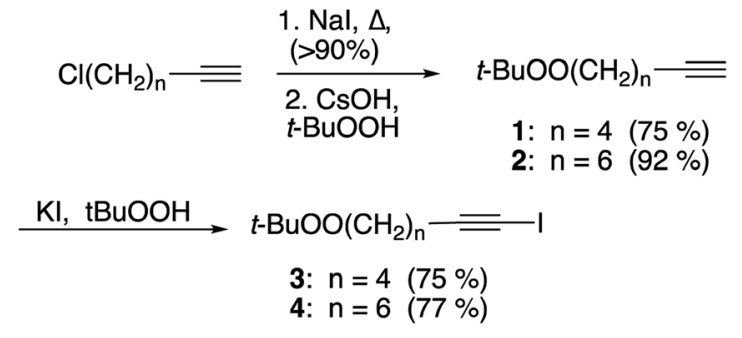

Scheme 1 Synthesis of alkynyl and iodoalkynyl peroxides.
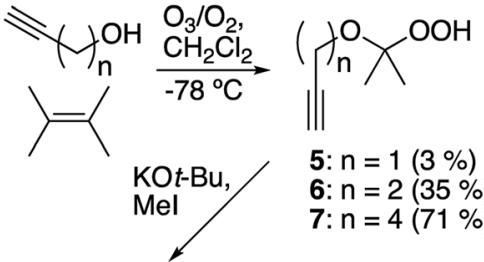

5: $n=1(3 \%)$ 6: $n=2(35 \%)$
7: $n=4(71 \%)$

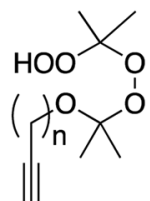

5a: $n=1(30 \%)$

6a: $n=2(10 \%)$
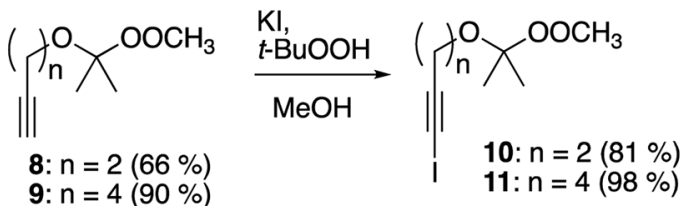

Scheme 2 Synthesis of alkynyl- and iodoalkynyl peroxyacetals

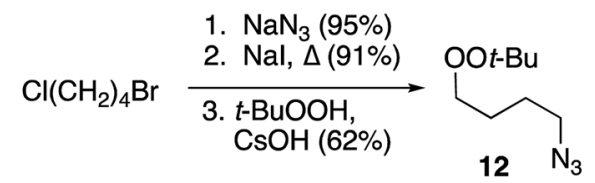

a. $\mathrm{Ph}_{3} \mathrm{P}, \mathrm{I}_{2}$ imid. $(75 \%)$

$\mathrm{HO}\left(\mathrm{CH}_{2}\right)_{4}$

b. $\mathrm{NaN}_{3}(98 \%)$

c. $\mathrm{Co}(\mathrm{acac})_{2}, \mathrm{O}_{2}$ $\mathrm{Et}_{3} \mathrm{SiH}(46 \%)$

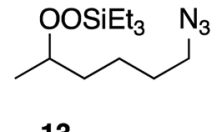

13 a nanomaterial platform widely applied for sensing, imaging, and biointeraction applications. ${ }^{14}$

\section{Results}

Substrates employed in CuAAC chemistry are illustrated in Fig. 1.

Unfunctionalized peroxyalkynes 1 and 2 were easily assembled (Scheme 1) via Finkelstein exchange on the corresponding chloroalkyne, ${ }^{15}$ followed by nucleophilic displacement of the iodide with tert-butyl hydroperoxide in the presence of $\mathrm{CsOH}^{\mathbf{1 6}}$ Iodination of the terminal alkyne furnished the corresponding iodoalkynes (3 and $\mathbf{4}$ ) in good yield. ${ }^{17}$

Preparation of alkynyl peroxyacetals was based upon trapping of an ozonolysis-derived carbonyl oxide with an alkynol (Scheme 2). ${ }^{18}$ This strategy, although rooted in the successful preparation of unsaturated hydroperoxyacetals from allyl alcohols, ${ }^{19}$ proved to be strongly dependent upon the structure of the alkynol. Ozonolysis of 2,3-dimethyl-2-butene in the presence of propargyl alcohol mainly afforded hydroperoxyperoxide 5a, which arises through reaction of the desired hydroperoxyacetal (5) with additional carbonyl oxide. The dimeric product predominates even in the presence of excess propargyl alcohol, presumably reflecting limited alcohol nucleophilicity. ${ }^{20}$ In contrast, the corresponding reactions of 3-butyn-1-ol and 5-hexyn-1-ol gave moderate and good yields of hydroperoxyacetals 6 and 7, respectively. The hydroperoxyacetals were readily methylated to afford peroxyacetals 8 and $9 .^{21}$ Iodination of the peroxyacetals furnished iodoalkynyl acetal 10 and 11.

Preparation of peroxide-substituted azides is summarized in Scheme 3. Selective nucleophilic substitution of 1-bromo-4chlorobutane afforded 1-chloro-4-azidobutane, ${ }^{22}$ which underwent $\mathrm{CsOH}$-promoted substitution with tert-butyl hydroperoxide to generate azidoalkyl peroxide 12. The synthesis of a secondary peroxide/azide began with conversion of 5-hexene-2-ol to the corresponding iodide. Nucleophilic displacement with sodium azide was followed by Mukaiyama peroxidation to generate peroxy azide 13. ${ }^{23}$ As 12 and 13 both incorporate two energy-rich groups within a low molecular weight framework, ${ }^{24}$ initial syntheses were conducted on modest scales $(\sim 1 \mathrm{mmol})$. Although both molecules

Table 1 Conditions for click chemistry with peroxy alkynes

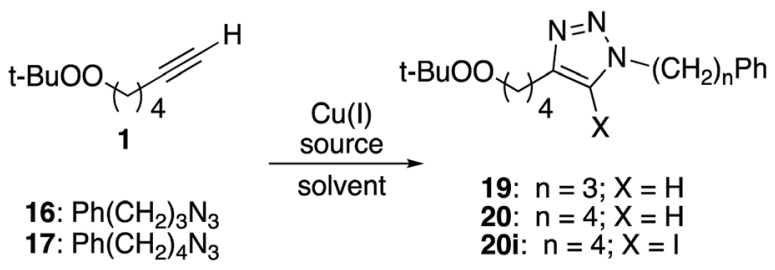

\begin{tabular}{|c|c|c|c|c|c|}
\hline Azide & $\mathrm{Cu}(\mathrm{I})$ source & Solv. & $t(\mathrm{~h})$ & Conv. & Prod. (yield, \%) \\
\hline 16 & $\mathrm{CuCl}, \mathrm{NEt}_{3}$ & THF & 3 & $89 \%$ & $19(25 \%)$ \\
\hline 17 & $\mathrm{CuI}, \mathrm{NEt}_{3}$ & THF & 3 & $80 \%$ & $\begin{array}{l}20(37 \%) \\
20 i(5 \%)\end{array}$ \\
\hline 17 & $\mathrm{CuSO}_{4}, \mathrm{Na}$ ascorbate & $\mathrm{CH}_{2} \mathrm{Cl}_{2} / \mathrm{H}_{2} \mathrm{O}$ & 1.5 & $85 \%$ & $20(42 \%)$ \\
\hline
\end{tabular}






proved to be stable to at least $100{ }^{\circ} \mathrm{C}$ (open chamber DSC, range limited by volatility), subsequent preparations were limited to $\leq 1 \mathrm{~g}$ and we avoided exposing either molecule to elevated temperatures. ${ }^{10}$ Preparations of 5-hexynyl benzene (15), azidoalkylbenzenes 16 and 17, and 6-azido hexanethiol (18) are detailed in the Experimental section.

\section{Copper(I) catalyzed click reaction with peroxy alkyne}

Reaction of peroxyalkyne 1 with azidoalkylbenzenes 16 or 17 under either homogeneous (CuI and $\mathrm{NEt}_{3}$, in THF) or biphasic $\left(\mathrm{CuSO}_{4}\right.$, sodium ascorbate, methylene chloride/water) conditions led to the rapid ( $\leq 15 \mathrm{~min}$ ) appearance of triazoles 19 or 20 (Table 1); ${ }^{12,25}$ the presence of a peroxide was evident based upon a redox-sensitive TLC indicator. ${ }^{26}$ These initial reactions were stopped after brief reaction periods (1.5-3 h); longer reaction times led to consumption of starting material but also contamination with a nearly inseparable byproduct later established to be the tetrazole aldehyde (21, vide infra). A small amount of the corresponding 5-iodotriazole $20 \mathrm{i}$, easily distinguished from 20 by the ${ }^{13} \mathrm{C}$ signal for $\mathrm{C}_{5}(120.7 \mathrm{ppm}$ for $\mathrm{C}-\mathrm{H}$ vs. $78.0 \mathrm{ppm}$ for $\mathrm{C}-\mathrm{I})$ was isolated from the reaction employing $\mathrm{CuI}^{27}$

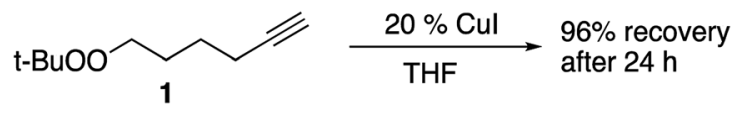

The relationship between reaction time and aldehyde formation was examined using the reaction of $\mathbf{1}$ and $\mathbf{1 7}$ (Table
2). Ratios of peroxide products $(\mathbf{2 0}, \mathbf{2 0 i}) v s$. aldehyde (21) were established by NMR; samples of pure aldehyde were also isolated for characterization. The near absence of aldehyde for reactions conducted in the presence of excess alkyne (entries 6 and 9) would emerge as an important tool (vide infra).

Resubjecting isolated triazole 20 to either set of reaction conditions led to formation of aldehyde 21 (eqn (1)); in the presence of $\mathrm{CuSO}_{4} /$ ascorbate, the aldehyde became the major product.

In an effort to better understand the factors leading to aldehyde formation, we probed the reactivity of triazole $\mathbf{2 0}$ towards reaction components (Table 3). No decomposition was observed in the presence of base or $\mathrm{CuSO}_{4}$ or ascorbate. However, treatment with $\mathrm{CuI}, \mathrm{CuI} /$ triethylamine, or $\mathrm{CuSO}_{4} / \mathrm{Na}$ ascorbate generated significant amounts of aldehyde; the same was true for reaction with either $\mathrm{Cu}(\mathrm{I})$ source and azide. No aldehyde was observed in the presence of mixtures containing added alkyne (entries 5, 6, 11 and 12) which did not result in aldehyde formation. Interestingly, the 5-iodotriazole (20i) was unaffected by conditions which rapidly degraded 20 (entry 13).

The results in Table 3 suggest that the formation of aldehyde may be accelerated in the presence of the neighboring triazole. Supporting this hypothesis, alkynyl peroxide $\mathbf{1}$ proved inert towards reaction with copper iodide in THF (eqn (2)).

Consistent with literature reports, ${ }^{28}$ click reactions proceeded more rapidly in the presence of tris[(1-benzyl- $1 H-1,2,3-$ triazol-4-yl)methyl]amine (TBTA), a $\mathrm{Cu}(\mathrm{I})$ ligand (Table 4). However, aldehyde formation continuing to be a problem and the overall yields of clicked peroxide were no greater, and sometimes less, than for reactions in the absence of the ligand. In contrast, performing the $\mathrm{CuI}$ or $\mathrm{CuSO}_{4} /$ ascorbate-catalyzed reactions in the presence of excess alkyne completely suppressed aldehyde formation. This led to the hypothesis that the lack of byproduct might reflect the ability of free alkyne to protonate the $\mathrm{C}_{5}$-cuprated triazole intermediate in CuAAC chemistry. ${ }^{12,29}$ We also investigated this reaction in the presence of a silane, a functionality also known to quench organocopper species, ${ }^{30}$ and again observed suppression of aldehyde formation. Finally, replacement of the terminal alkyne with an iodide furnished only the 5-iodoalkyl peroxide; no aldehyde was observed. These reactions, although allowed to proceed for $18-24 \mathrm{~h}$, were typically complete (TLC) within 30 minutes.

Iodoalkynes display enhanced reactivity relative to terminal alkynes in CuAAC reactions, ${ }^{27}$ and this is also observed in the reactions of the peroxide-substrates. A competition between

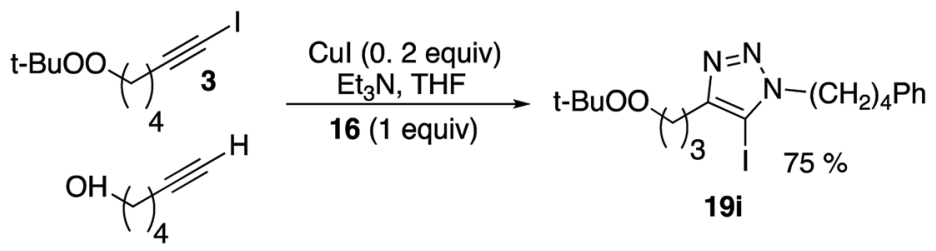


Table 2 Influence of reaction time on byproduct formation

$$
1+17 \underset{\text { solvent }}{\stackrel{0.2 \text { equiv } \mathrm{Cu}(\mathrm{l})}{\longrightarrow}}[2 \mathrm{O}, 2 \mathrm{Oi}]+\overbrace{\mathrm{CHO}}^{\stackrel{\mathrm{N}=\mathrm{N}}{\mathrm{N}}-{ }^{21}-\left(\mathrm{CH}_{2}\right)_{4} \mathrm{Ph}}
$$

\begin{tabular}{|c|c|c|c|c|}
\hline Entry & Catalyst & Solvent & $t(\mathrm{~h})$ & $21\left(\right.$ yield $\left.^{a}, \%\right)$ \\
\hline 1 & $\mathrm{CuI} / \mathrm{Et}_{3} \mathrm{~N}$ & THF & 1 & $6 \%$ \\
\hline 2 & $" 1$ & $" 1$ & 3 & $8 \%$ \\
\hline 4 & $"$ & $"$ & 18 & $20 \%$ \\
\hline 5 & " & " & 27 & $30 \%$ \\
\hline $6^{b}$ & " & " & 3 & $<2 \%$ \\
\hline 9 & " & " & 18 & $57 \%$ \\
\hline $10^{b}$ & " & $"$ & 1.5 & $5 \%$ \\
\hline $11^{b}$ & " & " & 4 & $22 \%$ \\
\hline
\end{tabular}

structurally analogous alkyne derivatives led to preferential consumption of the iodoalkynyl peroxide 3 .

\section{Proximity of peroxide and alkyne}

Click reactions of peroxyoctyne 2 and the corresponding iodoalkyne (4) produced a good yield of peroxy triazoles $22 / 23$
$\mathrm{Cu}(\mathrm{II})$, the reactions underwent a color change from dark green to light blue after 30-60 minutes. The color change could be temporarily reversed by the addition of more ascorbate but little or no clicked product was detected. Additionally, minimal progress was observed with the corresponding iodoalkynyl peroxyacetal (10).



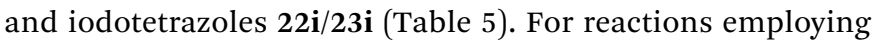
$\mathrm{CuI}$ as the copper source, formation of the aldehyde byproducts $24 / 25$ was minimal (2) or did not occur at all (4). In the case of reactions using $\mathrm{CuSO}_{4}$, aldehyde formation was significant for reactions involving alkyne 2 and minimal for iodoalkyne 4.

\section{Alkynyl peroxyacetals}

$\mathrm{Cu}(\mathrm{I})$-promoted reaction of the butynyl peroxyacetal (8) with azides 16 or 17 gave poor results (eqn (4)). In some cases, we observed successful click reaction to form inseparable mixtures of the desired peroxyacetal and the acetate ester derived from peroxyacetal fragmentation. No improvement was observed based upon the presence of excess alkyne, TBTA, or triethylsilane. In the presence of promoters derived from

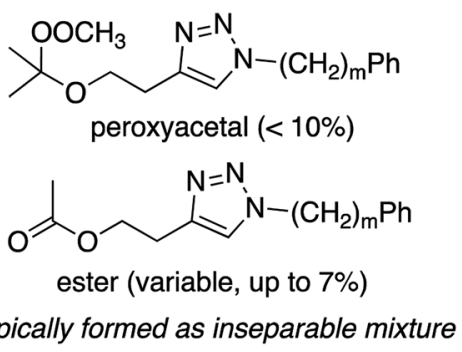

In contrast, the longer chain peroxyacetal (9) and the corresponding iodoalkyne (11) both reacted with azides in the presence of $\mathrm{Cu}(\mathrm{I})$ to give peroxy triazoles as the only major product (Table 6). Once again, no reaction was observed in the presence of a promoter derived from $\mathrm{CuSO}_{4} /$ ascorbate.

A separate control experiment (eqn (5)) made obvious the stability of the alkynyl peroxyacetals towards $\mathrm{Cu}(\mathrm{I})$ in the absence of other reaction components.

$$
8 \stackrel{20 \% \mathrm{Cul}}{\stackrel{\mathrm{THF}}{\longrightarrow}} \begin{gathered}
94 \% \\
\text { recovery }
\end{gathered}
$$

\section{CuAAC reactions of peroxyalkyl azides}

Reactions of simple alkynes with peroxide-containing azide $\mathbf{1 2}$ proceeded in modest yield using $\mathrm{CuI} / \mathrm{Et}_{3} \mathrm{~N}$ (Table 7); the 
Table 3 Stability of peroxide tetrazoles to reaction components

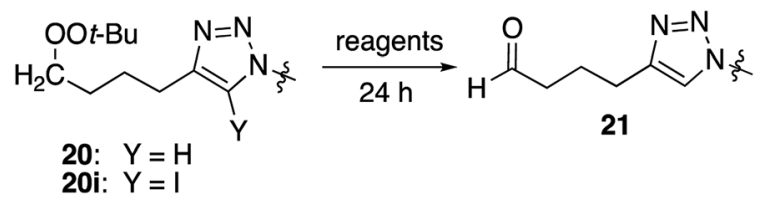

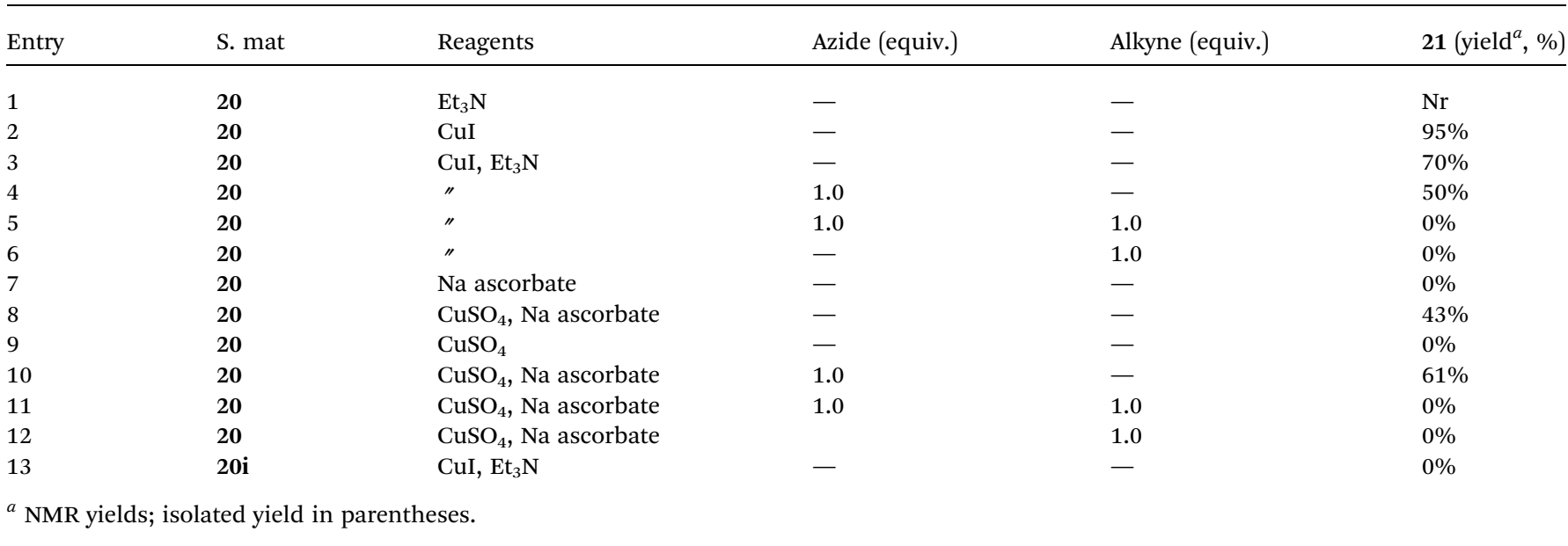

Table 4 Influence of additives

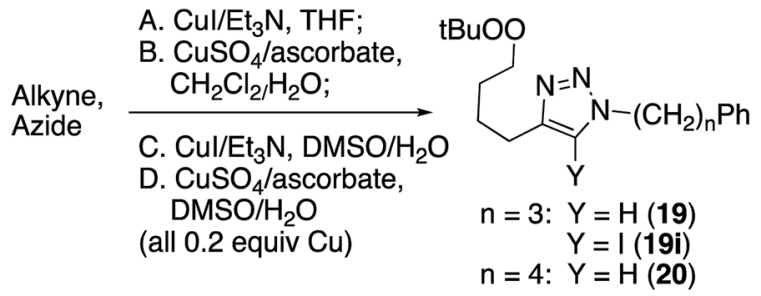

\begin{tabular}{|c|c|c|c|c|c|}
\hline Alkyne & Azide & Cond. & Additive (equiv.) & $\begin{array}{l}t \\
(\mathrm{~h})\end{array}$ & Product (yield, \%) \\
\hline 1 & 17 & A & Alkyne 1 (1.2) & 18 & $20(55 \%)$ \\
\hline 1 & 17 & $\mathrm{C}$ & ТВTA (1\%) & 3 & $20(20 \%)$ \\
\hline 1 & 17 & D & TBTA $(1 \%)$ & 3 & $20(35 \%)$ \\
\hline 1 & 16 & A & $\mathrm{Et}_{3} \mathrm{SiH}(1.2)$ & 24 & $19(62 \%)$ \\
\hline
\end{tabular}

corresponding reactions with $\mathrm{CuSO}_{4} /$ ascorbate provided lower yields and required substantially longer reaction times. In both series, significant amounts of the peroxyazide were recovered. Although analysis of these reactions was complicated by the presence of inseparable byproducts, we could verify that little or no aldehyde was generated under these conditions.

Secondary silyl peroxide $\mathbf{1 3}$ failed to give clicked products (eqn (6)); instead, producing a mixture of reduction and fragmentation products. ${ }^{10,31}$ In the absence of alkyne, $\mathbf{1 3}$ was stable to both the $\mathrm{CuI}$ or $\mathrm{CuSO}_{4}$ reagent systems (not shown).

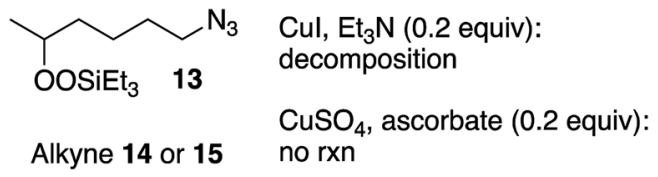

(6)

\section{Influence of peroxides on the CuAAC reaction}

The lower reactivity and yields observed with the peroxysubstituted azides led us to investigate whether the presence of a peroxide was exerting a general dampening influence on the CuAAC reaction. The reaction of 1-hexyne (14) and phenylalkyl 
Table 5 CuAAC reaction of longer dialkyl peroxide

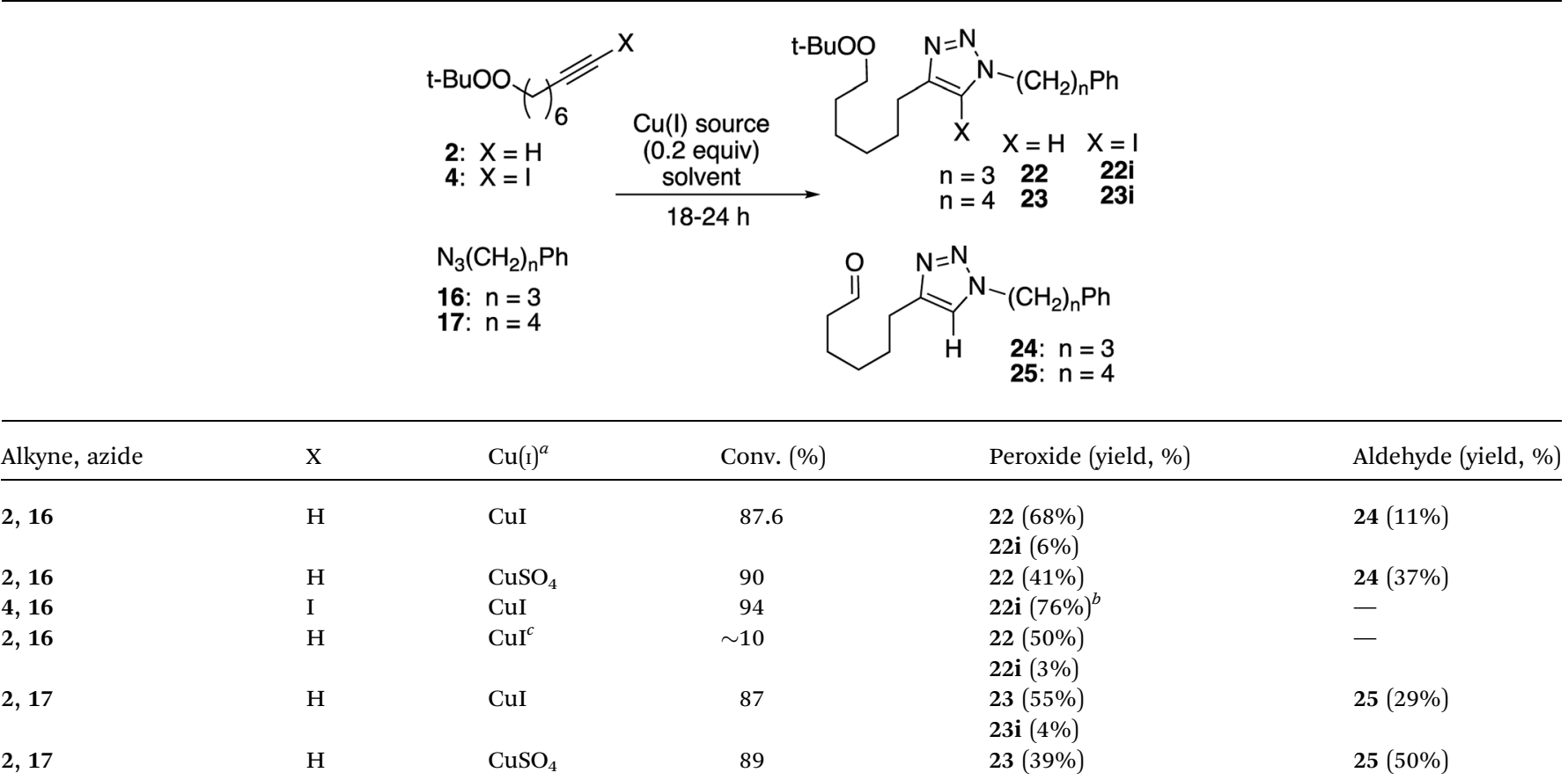

${ }^{a} \mathrm{CuI} / \mathrm{Et}_{3} \mathrm{~N}$ (0.2 equiv.), THF; $\mathrm{CuSO}_{4} /$ sodium ascorbate, DCM/ $\mathrm{H}_{2} \mathrm{O}$ (biphasic). ${ }^{b}$ Significant amount of unidentified polar byproduct. ${ }^{c} \mathrm{Et}_{3} \mathrm{SiH}(1.9$ equiv.) also present.

azide 17, which went to completion in just a few minutes under our typical reaction conditions, failed to proceed at all in the presence of a stoichiometric amount of peroxide 13 (eqn (7)).

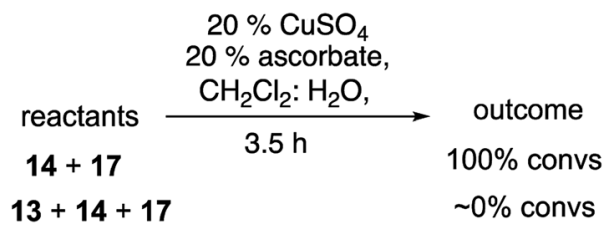

\section{Nanoparticle functionalization}

Having identified useful conditions for CuAAC reactions of alkynyl peroxides and peroxyacetals, we became interested in applying the chemistry to functionalization of nanoparticles. CuAAC-based functionalization of AuNPs, which exploits the high affinity of thiols for gold and the resulting ability to create azide-functionalized nanoparticles, has been widely applied to a variety of applications in both organic and aqueous media, ${ }^{11,14 a, 32-37}$ and we focused our attention on this system.

Azide-functionalized nanoparticles $\left(\mathbf{N}_{3} \mathbf{A u}\right)$ were prepared using a variant of a reported procedure in which $\mathrm{Au}$

Table 6 Click chemistry of hexynyl peroxyacetals

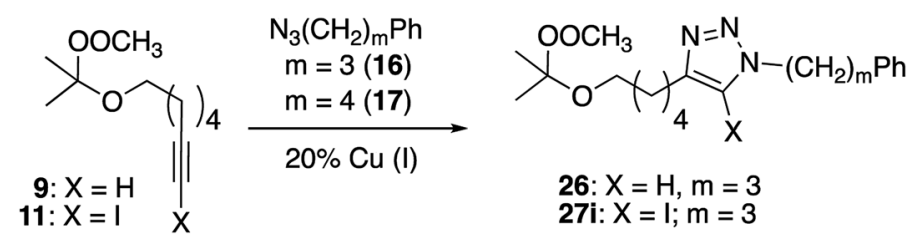

\begin{tabular}{|c|c|c|c|c|}
\hline 9 & 17 & $\mathrm{CuI}, \mathrm{Et}_{3} \mathrm{~N}$ & 3 & $26(45 \%)$ \\
\hline 11 & 16 & $\mathrm{CuI}, \mathrm{Et}_{3} \mathrm{~N}$ & 18 & $27 \mathbf{i}(33 \%)$ \\
\hline
\end{tabular}

${ }^{a}$ Isolated. 
Table 7 CuAAC chemistry with peroxyalkyl azides

\begin{tabular}{|c|c|c|c|c|}
\hline & $\begin{array}{c}t-\mathrm{BuOO}\left(\mathrm{CH}_{2}\right)_{4} \mathrm{~N}_{3} \\
12 \\
\mathrm{R}\left(\mathrm{CH}_{2}\right)_{3}= \\
14: \mathrm{R}=\mathrm{Me} \\
15: \mathrm{R}=\mathrm{Ph}\end{array}$ & & $\%)$ & \\
\hline Alkyne & Reagents & $t(\mathrm{~h})$ & Conv. (12) & Product (yield, \%) \\
\hline 14 & $\mathrm{CuI} / \mathrm{Et}_{3} \mathrm{~N}$ & 3 & $71 \%$ & $28(34 \%)$ \\
\hline 14 & $\mathrm{CuSO}_{4} / \mathrm{Na}$ ascorbate & 24 & $80 \%$ & $28(29 \%)$ \\
\hline 15 & $\mathrm{CuI} / \mathrm{Et}_{3} \mathrm{~N}$ & 3 & $76 \%$ & $29(15 \%)$ \\
\hline 15 & $\mathrm{CuSO}_{4} / \mathrm{Na}$ ascorbate & 24 & $42 \%$ & $29(\leq 5 \%)$ \\
\hline
\end{tabular}

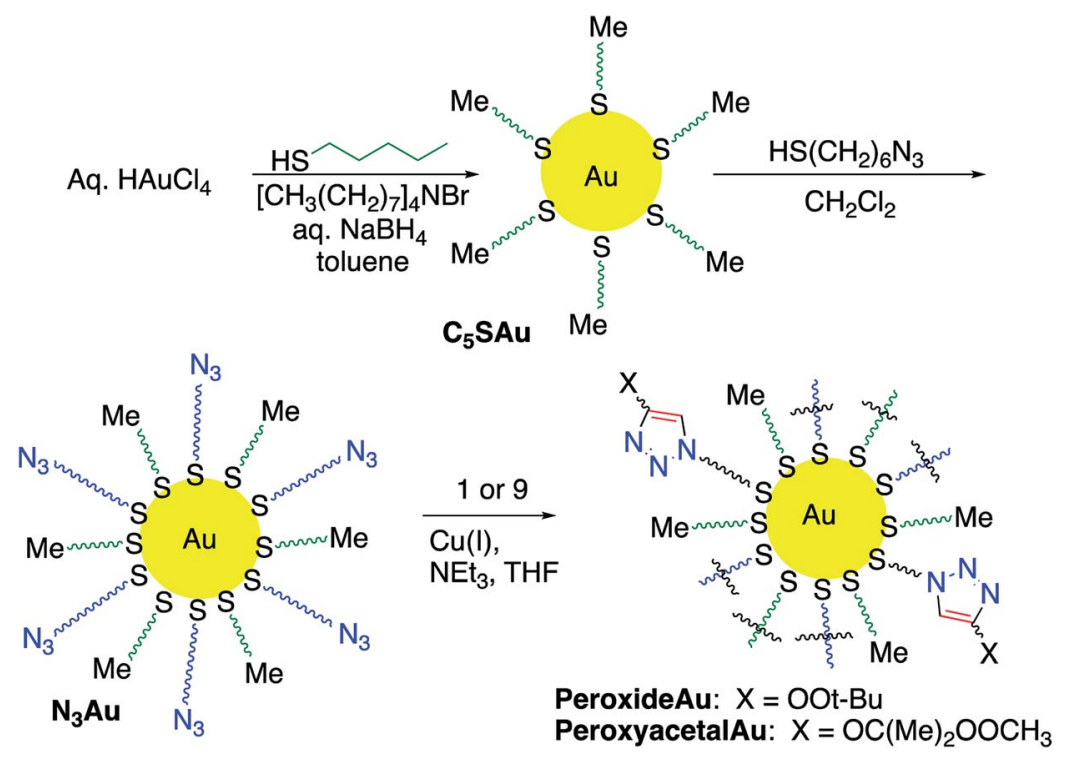

Scheme 4 Synthesis of peroxide-functionalized nanoparticles.

nanoparticles (AuNP) are subsequently reacted with a passivating and then a functionalized thiol (Scheme 4$) \cdot{ }^{38}$ Addition of a slight excess of pentanethiol to a biphasic mixture of $\mathrm{HAuCl}_{3}$ and tetraoctylammonium bromide resulted in a white suspension which reacted with freshly prepared aqueous sodium borohydride to generate a dark and opaque suspension of pentanethiolate-functionalized nanoparticles $\left(\mathbf{C}_{5} \mathbf{S A u}\right)$. The partially passivated nanoparticles were isolated by centrifugation. ${ }^{11 c}$ TEM (Fig. 2) spectra confirmed the presence of 2$5 \mathrm{~nm}$ particles. The presence of the alkylthio chains was evident by the ${ }^{1} \mathrm{H}$ signals for a terminal methyl group and the methylene groups at $\mathrm{C}_{3} / \mathrm{C}_{4}$ (ESI-Fig. $1 \dagger$ ). ${ }^{39} \mathrm{XPS}$ analysis revealed the surface region of the nanoparticles to consist of $50.1 \% \mathrm{Au}, 43.9 \% \mathrm{C}$, and $6.0 \% \mathrm{~S}$, suggesting that approximately $75 \%$ of the Au surface remained accessible for further functionalization (ESI-Fig. $2-4 \dagger$ ). ${ }^{\mathbf{4 0}}$ Repetition of the procedure using dodecanethiol, the preliminary passivating agent described in the original report, generated nanoparticles with similar properties (ESI-Fig. 5-8†). ${ }^{11 c}$

Treatment of the $\mathbf{C}_{5} \mathbf{S H}$-Au with excess 6-azidohexane thiol furnished the azide-modified nanoparticle $\left(\mathbf{N}_{3} \mathbf{A u}\right)$ which was isolated and purified using centrifugation and resuspension. The presence of the azide was evident from the strong IR absorbance at $2094 \mathrm{~cm}^{-1}$ (Fig. 3, compare panels a and b) and

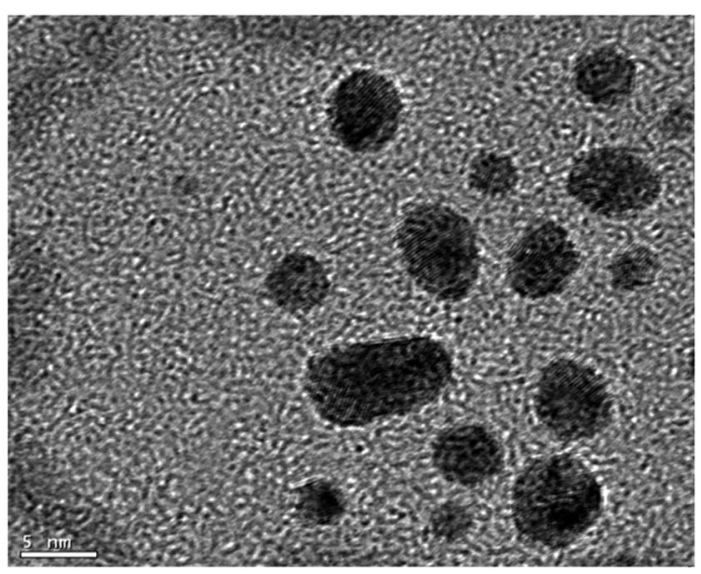

Fig. 2 TEM of C5SAu. Scale bar $=5 \mathrm{~nm}$. 

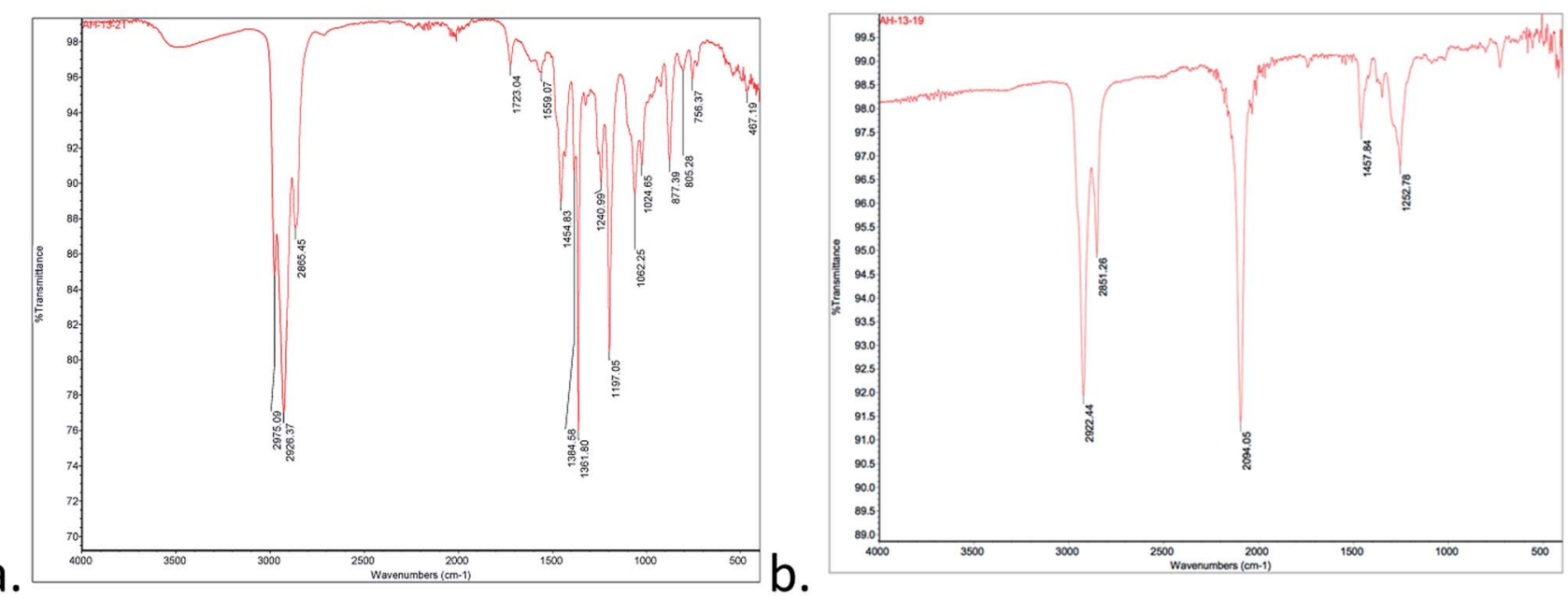

C.
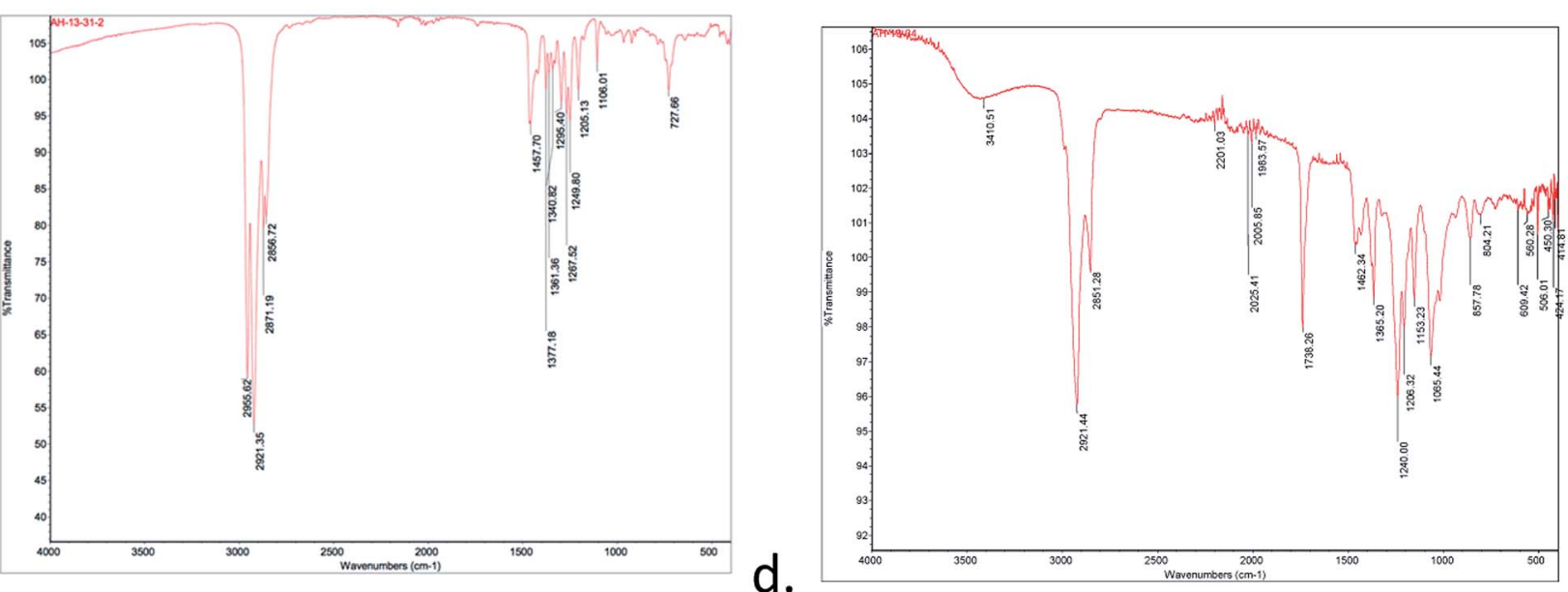

Fig. 3 IR of nanoparticles: (a) $\mathrm{C}_{5} \mathrm{SAu}$; (b) $\mathrm{N}_{3} \mathrm{Au}$; (c) after click with peroxyalkyne 1; (d) after click with alkynyl peroxyacetal 9.

by the new ${ }^{1} \mathrm{H}$ NMR signal at $3.31 \mathrm{ppm}$ corresponding to $\mathrm{CH}_{2} \mathrm{~N}_{3}$ (ESI-Fig. 9†); this signal was easily distinguished from signal for unbound azide (3.50 ppm), which was also observed in inadequately washed samples. The $\sim 2: 3$ ratio of the integrals for the signals corresponding to $\mathbf{C H}_{2} \mathrm{~N}_{3}$ vs. $\mathrm{CH}_{2} \mathbf{C H}_{3}$ suggests a similar extent of coverage. XPS suggested a surface composition of $54.0 \% \mathrm{Au}, 34.2 \% \mathrm{C}, 8.5 \% \mathrm{~S}$, and $3.3 \%$ (ESI-Fig. $10-13 \dagger$ ).

\section{Peroxide functionalization of nanoparticles}

Addition of triethylamine and cat. copper iodide into a THF solution containing peroxyalkyne $\mathbf{1}$ and $\mathbf{N}_{3} \mathbf{A u}$ led to the immediate appearance of a new peroxide-active spot on TLC (see Experimental details). ${ }^{26}$ After being quenched with aq. $\mathrm{NH}_{4} \mathrm{Cl}$, the reaction was concentrated and the residue purified away from residual reactant by repeated resuspension $(\mathrm{MeOH})$ and centrifugation. The azide stretch was now absent in the IR spectrum (Fig. 3d), which instead showed weak tetrazole-related stretches at $1723 \mathrm{~cm}^{-1}$ and $1559 \mathrm{~cm}^{-1}$ and only minimal absorptions associated with an aldehyde $\left(1705-1710 \mathrm{~cm}^{-1}\right)$. Evidence for the click reaction could also be seen in the ${ }^{1} \mathrm{H}$ NMR (ESI-Fig. 14 $\dagger$ ) as the loss of the $\delta 3.31$ signal corresponding to the $\mathrm{CH}_{2} \mathrm{~N}_{3}$ and new signals at $1.27(t-\mathrm{Bu})$ and $3.99(\mathrm{OO})$. XPS established a product composition of $26.4 \% \mathrm{Au}$ and $73.6 \%$ pentanethiol and peroxide triazole (ESI-Fig. 15-19†).

We also investigated click functionalization of azidoNP with alkynyl peroxy acetal 9. Consumption of the azide was obvious in the lack of the $\sim 2100 \mathrm{~cm}^{-1}$ IR stretch and the observation of a new C-H stretch at $2921 \mathrm{~cm}^{-1}$ (Fig. 3d). Although ester formation was equally obvious as an IR stretch at $1738 \mathrm{~cm}^{-1}$, the limited magnitude of this peak, combined with the comparison in the ${ }^{1} \mathrm{H}$ NMR (ESI-Fig. $20 \dagger$ ) of signals for the $\mathrm{MeOO}(3.54 \mathrm{ppm})$ and the gem-dimethyl groups of the acetal $(1.57 \mathrm{ppm}) v s$. the peak group at $3.86 \mathrm{ppm}\left(\mathrm{CH}_{2} \mathrm{O}\right)$ of both acetal and ester, suggested the majority of the functionalized chain remained as peroxyacetal. XPS (ESI-Fig. 21-25†) suggested a surface composition of $20.0 \% \mathrm{Au}$ and $80.0 \%$ pentanethiol and peroxyacetal triazole.

\section{Discussion}

Our results demonstrate that both peroxides and peroxyacetals can, under suitable conditions, serve as modular components for $\mathrm{Cu}$-promoted CuAAC click reactions. The click reactions of the alkynyl peroxides and peroxyacetals proceed at rates in line with literature reports, with reactions times of $0.5-1 \mathrm{~h}$ for 
terminal alkynes and $\leq 0.75 \mathrm{~h}$ for 1-iodoalkynes. ${ }^{12,27}$ This is consistent with Zhu's observation that electron-poor alkynes are excellent substrates for CuAAC reactions. ${ }^{41}$ An "isomeric" set of click reactions involving simple alkynes and azidoalkyl peroxides is less efficient. The basis for inhibition of azide reactivity at a four-carbon distance from a peroxide remains unclear; however, we should note that we have observed a dampening influence of peroxides on $\mathrm{S}_{\mathrm{N}} 2$ reactions across a similar span. ${ }^{42}$

The use of $\mathrm{CuI}$ in organic solvents gives more consistent and often superior results compared to the use of $\mathrm{CuSO}_{4} /$ ascorbate in biphasic media. The alkynyl peroxides and alkynyl peroxyacetal substrates, although stable towards $\mathrm{Cu}(\mathrm{I})$, are both prone to decomposition reactions in the presence of the reaction intermediates (Scheme 5). Interestingly, the efficiency of the reactions, the nature of the decomposition reactions, and the approaches to control of decomposition, are different for the two classes of substrates.

The dialkyl peroxides give modest to moderate yields under traditional CuAAC conditions due to the accumulation of a byproduct derived from fragmentation of the peroxide to an aldehyde. Aldehyde formation can be suppressed by use of an iodinated alkyne substrate, by performance of reactions in the presence of excess alkyne or added silane; under these conditions the yield of clicked peroxide is in the range of $62-68 \%$. For the peroxyacetals, reactions proceed in lower yield, and, in the case of a shorter chain series (8), generate a significant amount of a byproduct in which the peroxyacetal has been fragmented to an acetoxy group. The formation of the ester is largely suppressed in a longer-chain peroxyacetal or for reactions of iodoalkynyl peroxyacetals. However, regardless of conditions, the yields obtained from peroxyacetals do not rival those obtained from the dialkyl peroxides.

An interpretation of our results in the context of the accepted mechanism of the CuAAC reaction (Scheme 6) suggests the decomposition reactions result from interaction of the peroxide or peroxyacetal with a heteroaryl organocopper intermediate generated at $\mathrm{C}_{5}$ of the developing triazole. ${ }^{12}$ Evidence in support of this hypothesis includes: the instability of the peroxyalkyne to any mixture containing $\mathrm{Cu}(\mathrm{I})$ and triazole; the lack of fragmentation observed for iodoalkynes; and the minimization of fragmentation the presence of excess alkyne or added triethylsilane, either of which would be expected to protonate the

Peroxides: side reaction observed for $n=3$ or 5 ; no fragmentation if $\mathrm{X}=\mathrm{I}$

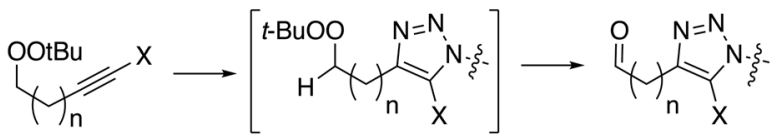

Peroxyacetals: fragmentation observed for $n=1$ but not $n=3$



Scheme 5 Overview of decomposition processes.

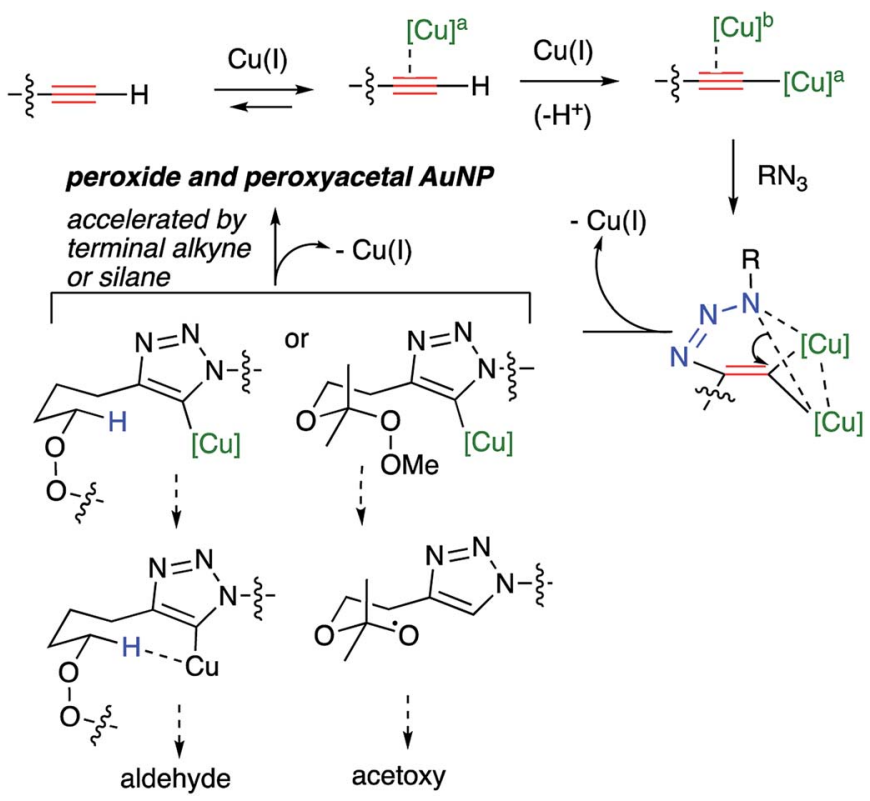

Scheme 6 CuAAC mechanism and potential pathways for peroxide fragmentation.

$\mathrm{sp}^{2}-\mathrm{RCu} .^{30}$ The clean formation of aldehyde, and the high barriers associated with electrochemical or chemical reduction of dialkyl peroxides, ${ }^{43}$ suggest the decomposition is a heterolytic process involving abstraction of the adjacent $\mathrm{C}-\mathrm{H} .^{\mathbf{1 a}}$

The formation of an ester group (acetoxy) from fragmentations of the hydroperoxyacetals suggests the intermediacy of an alkoxy radical derived from cleavage of the peroxyacetal by an electron-donor; the likely reducing agent is the metalated triazole described above (Scheme 6). ${ }^{44}$ In contrast to the reactions of dialkyl peroxides, byproduct formation for the peroxyacetals is not suppressed by the presence of excess alkyne or added silane; it is suppressed by use of iodoalkynyl substrates or by increasing the peroxide/alkyne distance.

It is interesting to compare our results with reported CuAAC reactions of alkynyl derivatives of artemisinin-derived propargyl acetals and amides (Fig. 4); the approximate distance between the peroxide and the reaction site is similar in both systems. ${ }^{13}$ The heterolytic fragmentation we observed with dialkyl peroxides is not available in the artemisinin derivatives due to the lack of adjacent $\mathrm{C}-\mathrm{H}$ groups. However, the fact that radical fragmentations are not observed in the artemisinin derivatives may indicate that the SET fragmentation requires close approach of the organocopper intermediates and the peroxyacetal, something that is possible in A and B and not possible in $\mathrm{C}$ or $\mathrm{D}$.

CuAAC-based functionalization of AuNPs, which exploits the high affinity of thiols for gold has been widely applied to a variety of applications in both organic and aqueous media. ${ }^{11,, 14 b, c, 32-37}$ At the outset of our studies, we were concerned by reports suggesting that CuAAC reactions on gold nanoparticles require longer reaction periods or use of microwave heating, ${ }^{45,46}$ and can be accompanied by nanoparticle aggregation and precipitation. ${ }^{\mathbf{4 5 , 4 7}}$ Our results indicated that modular introduction of peroxides on nanoparticles via CuAAC suffers 


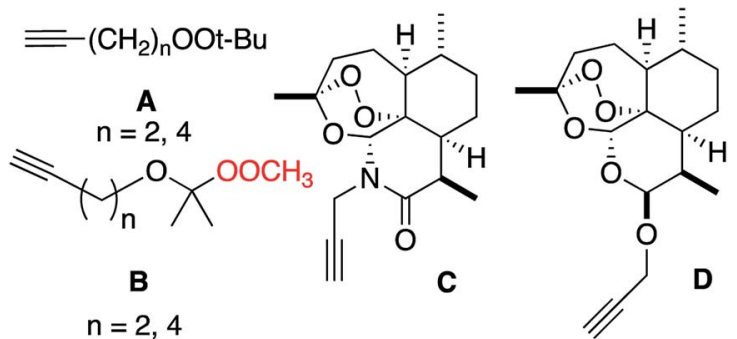

$$
\begin{array}{lcccc}
\operatorname{Span}\left(\mathrm{C}_{\mathrm{sp}}-\mathrm{O}_{\text {peroxide }),}\right. & \text { A } & \text { B } & \text { C } & \text { D } \\
\cline { 2 - 5 } \text { atoms } & 4-6 & 4-6 & 4 & 6
\end{array}
$$

Fig. 4 Comparison with artemisinin-derived "click" substrates.

from no such limitations, and can be performed in less than eight hours and in the absence of microwave heating. Installation of dialkyl peroxides proceeds cleanly even in the absence of additives required in solution reactions, suggesting that the high local concentration of alkyne relative to the surface $\mathrm{N}_{3}$ groups suppresses aldehyde formation. Peroxyacetals, which are much more activated than dialkyl peroxides towards cleavage, ${ }^{6,43}$ also undergo successful click reactions on surfaces. However, in this case, the side reaction observed in solution phase chemistry continued to be observed in reactions on nanoparticles. This reaction, in contrast to some results on the extremely hindered peroxyacetal core of artemisinin, is suppressed by the use of a substrate containing a greater span between the peroxide and alkyne groups.

With the exception of functionalized SAMs displaying peroxides (via ozonolysis of alkene-terminated monolayers) ${ }^{8}$ or diacyl peroxides (via condensation of $\mathrm{H}_{2} \mathrm{O}_{2}$ with carboxylic acids) ${ }^{48,49}$ there are few examples of covalent introduction of peroxide on surfaces. Much of this is likely to relate to concerns about compatibility of the surface with the functionalization method; for example, ozone is known to attack the thiol/Au interface and is incompatible with many electron-rich groups. ${ }^{18 b, 50}$ Our work demonstrates that the CuAAC reaction can be used to install both dialkyl peroxides and the more reactive peroxyacetals on nanoparticle surfaces.

\section{Conclusions}

Our work, the first systematic investigation of the factors influencing the use of click reactions for installing organic peroxides, demonstrates that the copper-assisted click offers a practical approach for modular introduction of dialkyl peroxides and peroxyacetals. The best results are obtained with dialkyl peroxides; a side reaction involving heterolytic fragmentation of the peroxide can be easily circumvented by choice of substrate or additive. Although installation of more reactive peroxyacetals can be complicated by a radical fragmentation, this process can be minimized by use of a greater span between the peroxide and the reaction site.

Our work also provides first example of the use of click chemistry for modular introduction of organic peroxides on surfaces. Reactions are rapid, proceed to high conversion of nanoparticle surface functionality, and can be accomplished under mild conditions and without nanoparticle aggregation. Peroxide-functionalized surfaces could provide the basis for reactive or antimicrobial coatings, ${ }^{51}$ as well as a platform for investigating spatially-constrained interactions or reactions of peroxides or derived reactive oxygen species. ${ }^{52}$ Along these lines, the peroxyacetals investigated here, in addition to offering a source of alkoxy radicals, are known to be easily hydrolyzed to generate free hydroperoxides ${ }^{16}$ while the simple $t$-alkyl peroxides, although nearly inert to simple reducing agents and Fe(II), are known to be activated photochemically ${ }^{5,53}$ or by iron/thiol complexes. $^{43}$

\section{Experimental procedures}

\section{General methods}

All reagents and solvents were used as purchased except for $\mathrm{CH}_{2} \mathrm{Cl}_{2}$ (distilled from $\mathrm{CaH}_{2}$ ), DMF (vacuum distilled from $\mathrm{CaH}_{2}$ ), and THF (distilled from $\mathrm{Na} / \mathrm{Ph}_{2} \mathrm{CO}$ ). All nonaqueous reactions were conducted under an atmosphere of $\mathrm{N}_{2}$ in flamedried glassware. Thin layer chromatography (TLC) was performed on $0.25 \mathrm{~mm}$ hard-layer silica plates. Developed plates were visualized by $254 \mathrm{~nm}$ UV lamp and/or by staining: $2.5 \%$ ammonium molybdate and $0.5 \%$ ceric sulfate in $10 \%$ aqueous sulfuric acid (general stain, after heating); $1 \%$ aq. potassium permanganate (alkynes); $1 \% \quad N, N^{\prime}$-dimethyl- $p$-phenylenediamine in $1: 20: 100$ acetic acid/water/methanol (specific for peroxides; dialkyl peroxides and peroxyacetals can be visualized as a reddish or reddish-green spot upon heating); ${ }^{26}$ or vanillin and sulfuric acid (3\% each) in ethanol (general stain, after heating). Unless otherwise described, chromatography refers to silica flash chromatography.

NMR spectra were acquired in $\mathrm{CDCl}_{3}$ at $400\left({ }^{1} \mathrm{H}\right)$ or $100 \mathrm{MHz}$ $\left({ }^{13} \mathrm{C}\right)$ unless otherwise noted. Chemical shifts are reported relative to residual chloroform $\left(7.26 \mathrm{ppm},{ }^{1} \mathrm{H} ; 77.36 \mathrm{ppm},{ }^{13} \mathrm{C}\right)$. ${ }^{1} \mathrm{H}$ spectra are reported as chemical shift (multiplicity, $J$ couplings in $\mathrm{Hz}$, number of protons). IR spectra were recorded as neat films on a ZrSe crystal; selected absorbances are reported in $\mathrm{cm}^{-1}$. High resolution mass spectra (HRMS) were obtained at the Nebraska Center for Mass Spectrometry at UNL. XPS and TEM spectra were acquired in the Nebraska Center for Nanoscience and Materials on a Thermo Scientific K-Alpha Xray photoelectron spectrometer using a monochromated $\mathrm{Al} \mathrm{K \alpha}$ $(1486.6 \mathrm{eV})$ X-ray source and a dual-beam flood source using a FEI Tecnai Osiris (scanning) transmission electron microscope.

CAUTION: Although we experienced no exotherms or explosions during the reported investigations, any work with peroxides of moderate or high active oxygen content, in particular any steps involving heating and/or concentration, should be conducted following standard precautions (adjusting scale to perceived hazard; concentration, and when necessary, reaction behind shields; some analysis of the thermal sensitivity of new products). Readers are directed towards a web-published overview of peroxide safety. ${ }^{10 d}$ 


\section{Synthesis of peroxyalkynes}

6-(tert-Butylperoxy)-1-hexyne (1) was prepared by an adaptation of published procedures. ${ }^{54}$ To a solution of 6-chloro-1-hexyne $(4.66 \mathrm{~g}, 40.0 \mathrm{mmol})$ in acetone $(150 \mathrm{~mL})$ was added sodium iodide (32.98 g, $220.0 \mathrm{mmol}, 5.5$ equiv.). The reaction was stirred under reflux for 18 hours. The cooled reaction was then diluted with water $(50 \mathrm{~mL})$ and extracted with hexanes $(50 \mathrm{~mL} \times$ 3 ). The combined organic layers were dried with $\mathrm{Na}_{2} \mathrm{SO}_{4}$ and the residue concentrated under reduced pressure to yield $7.5307 \mathrm{~g}$ (91\%) of 6-iodo-1-hexyne as a yellow oil which was used without purification. Spectral details matched those previously reported. ${ }^{15,55} R_{\mathrm{f}}=0.42(10 \% \mathrm{EA} / \mathrm{Hex}) ;{ }^{1} \mathrm{H} \delta 3.20(\mathrm{t}, J=8.0,2 \mathrm{H}), 2.22$ $(\mathrm{td}, J=3.5, J=9.3,2 \mathrm{H}), 1.92(\mathrm{t}, J=9.3,1 \mathrm{H}), 1.63(\mathrm{p}, J=6.4,2 \mathrm{H})$; ${ }^{13} \mathrm{C} \delta$ 83.7, 69.0, 32.3, 29.2, 17.5, 6.2.

To a solution of CsOH monohydrate $(4.50 \mathrm{~g}, 30.0 \mathrm{mmol}, 1.2$ equiv.) in DMF $(100 \mathrm{~mL})$ at $0{ }^{\circ} \mathrm{C}$ was added dropwise TBHP as an $\sim 5.5$ M solution in decane ( $6.81 \mathrm{~mL}, 37.5 \mathrm{mmol}, 1.5$ equiv.). The mixture was stirred for $30 \mathrm{~min}$, whereupon 6-iodo-1-hexyne $(5.20 \mathrm{~g}, 25.0 \mathrm{mmol})$ was added. The reaction was allowed to slowly warm to room temperature. After $5 \mathrm{~h}$, the reaction was quenched with water $(30 \mathrm{~mL})$ and extracted with hexanes $(30 \mathrm{~mL}$ $\times 3$ ). The combined organic layers were dried with $\mathrm{Na}_{2} \mathrm{SO}_{4}$, concentrated under reduced pressure and the residue purified by column chromatography (5\% EA/Hex) to yield $3.981 \mathrm{~g}(94 \%)$ of 6-(tert-butylperoxy)-1-hexyne as a colorless oil. Spectral details matched previous reports: ${ }^{54 a} R_{\mathrm{f}}=0.56(10 \% \mathrm{EA} / \mathrm{Hex}){ }^{1} \mathrm{H}$ $\delta 3.96(\mathrm{t}, J=6.4,2 \mathrm{H}), 2.22(\mathrm{td}, J=7.0, J=2.6,2 \mathrm{H}), 1.94(\mathrm{t}, J=2.6$, $1 \mathrm{H}), 1.72(\mathrm{~m}, 2 \mathrm{H}), 1.61(\mathrm{~m}, 2 \mathrm{H}), 1.24(\mathrm{~s}, 9 \mathrm{H}) ;{ }^{13} \mathrm{C} \delta 84.3,80.2$, 74.5, 68.6, 27.2, 26.5, 25.4, 18.4; IR: 3314, 2924, 2119, 1362, 1198, 628; HRMS (ESI ${ }^{+}$, TOF) calcd for $\mathrm{C}_{10} \mathrm{H}_{18} \mathrm{NaO}_{2}[\mathrm{M}+\mathrm{Na}]^{+}$: 193.1204; found: 193.1205.

8-(tert-Butylperoxy)-1-octyne (2) was prepared by a similar procedure as described above. Reaction of 8-chloro-1-octyne (3.3914 g, $23.45 \mathrm{mmol})$ and sodium iodide $(19.366 \mathrm{~g}$, $129.2 \mathrm{mmol}, 5.5$ equiv.) furnish $5.0135 \mathrm{~g}$ (91\%) of 8-iodo-1-octyne as a yellow oil which was used without further purification. Spectral details matched those previously reported: ${ }^{56} R_{\mathrm{f}}: 0.43$ (10\% EA/ Hex); ${ }^{1} \mathrm{H} \delta 3.19(\mathrm{t}, J=7.0,2 \mathrm{H}), 2.19(\mathrm{td}, J=6.6, J=2.2,2 \mathrm{H}), 1.94(\mathrm{t}, J$ $=2.6,1 \mathrm{H}), 1.83(\mathrm{p}, J=6.7,2 \mathrm{H}), 1.53(\mathrm{~m}, 2 \mathrm{H}), 1.41-1.43(\mathrm{~m}, 4 \mathrm{H}) ;{ }^{13} \mathrm{C}$ $\delta$ 84.5, 68.4, 33.5, 30.1, 28.3, 27.7, 18.4, 7.1.

By the same method as employed for synthesis of $\mathbf{1}$, reaction of the iodooctyne $(3.8046 \mathrm{~g}, 16.50 \mathrm{mmol})$ with $\mathrm{CsOH}$ monohydrate (3.310 g, $22.1 \mathrm{mmol}, 1.3$ equiv.) and TBHP as an $\sim 5.5 \mathrm{M}$ solution in decane $(4.50 \mathrm{~mL}, 24.75 \mathrm{mmol}, 1.5$ equiv., $\sim 5.5 \mathrm{M}$ solution in decane) in DMF, furnished $3.0118 \mathrm{~g}$ (92\%) of 8-(tertbutylperoxy)-1-octyne (2) as a colorless oil: $R_{\mathrm{f}}$ : 0.55 (10\% EA/ Hex); ${ }^{1} \mathrm{H} \delta 3.93(\mathrm{t}, J=6.6,2 \mathrm{H}), 2.18(\mathrm{td}, J=6.9, J=2.5,2 \mathrm{H})$, $1.93(\mathrm{t}, J=2.6,1 \mathrm{H}), 1.50-1.64(\mathrm{~m}, 4 \mathrm{H}), 1.35-1.46(\mathrm{~m}, 4 \mathrm{H}), 1.24(\mathrm{~s}$, $9 \mathrm{H}) ;{ }^{13} \mathrm{C} \delta 84.7,80.2,75.1,68.3,28.7,28.5,27.9,26.4,25.8,18.4$ IR: 3312, 2945 (s), 2956, 1456, 1360 (s), 1198 (s); HRMS (ESI ${ }^{+}$, TOF) calcd for $\mathrm{C}_{12} \mathrm{H}_{22} \mathrm{NaO}_{2}[\mathrm{M}+\mathrm{Na}]^{+}$: 221.1517; found: 221.1510 .

1-Iodo-6-tert-butylperoxy hexyne (3) was prepared using an adaptation of a published procedure. ${ }^{17}$ To a solution of 6-(tertbutylperoxy)-1-hexyne (850 mg, $4.99 \mathrm{mmol})$ in $\mathrm{MeOH}(20 \mathrm{~mL})$ was added KI (1.02 g, $6.13 \mathrm{mmol}, 1.2$ equiv.), followed by TBHP as an $\sim 5.5 \mathrm{M}$ solution in decane $(1.36 \mathrm{~mL}, 7.48 \mathrm{mmol}, 1.2$ equiv.). The reaction was stirred at room temperature for 18 hours. The reaction was quenched with saturated aqueous $\mathrm{Na}_{2} \mathrm{~S}_{2} \mathrm{O}_{3}(10 \mathrm{~mL})$, washed with brine $(10 \mathrm{~mL})$, and extracted with EA $(15 \mathrm{~mL} \times 3)$. The combined organic layers were dried with $\mathrm{Na}_{2} \mathrm{SO}_{4}$, and the residue concentrated under reduced pressure to yield $1.1083 \mathrm{~g}(75 \%)$ of iodoalkynyl peroxide 3 as a light yellow oil: $R_{\mathrm{f}}=0.55(20 \% \mathrm{EA} / \mathrm{Hex}) ;{ }^{1} \mathrm{H} \delta 3.95(\mathrm{t}, J=6.3,2 \mathrm{H}), 2.40(\mathrm{t}, J=$ $6.8,2 \mathrm{H}), 1.70(\mathrm{p}, J=6.1,2 \mathrm{H}), 1.59(\mathrm{p}, J=7.0,2 \mathrm{H}), 1.24(\mathrm{~s}, 9 \mathrm{H})$ ${ }^{13} \mathrm{C} \delta$ 94.4, 80.3, 74.4, 27.2, 26.5, 25.4, 20.8, -6.8; IR 2925, 1362, 1196, 877; HRMS (ESI ${ }^{+}$, TOF) calcd for $\mathrm{C}_{10} \mathrm{H}_{17} \mathrm{INaO}_{2}[\mathrm{M}+\mathrm{Na}]^{+}$: 319.0171; found: 319.0174 .

1-Iodo-8-tert-butylperoxy octyne (4). By a similar procedure as employed for synthesis of iodohexynyl peroxide 3 , reaction of 8-(tert-butylperoxy)-1-octyne (714.9 mg, $3.60 \mathrm{mmol}), \quad$ KI (685.5 mg, $4.13 \mathrm{mmol}, 1.2$ equiv.), and TBHP (1.0 mL, $5.5 \mathrm{mmol}$, 1.5 equiv.) furnished, after column chromatography ( $10 \% \mathrm{EA} / \mathrm{Hex})$, $901.1 \mathrm{mg}$ (77\%) of iodooctynyl peroxide 4 as a light yellow oil: $R_{\mathrm{f}}$ : 0.57 (20\% EA/Hex); ${ }^{1} \mathrm{H} \delta 3.95(\mathrm{t}, J=6.7,2 \mathrm{H}), 2.38(\mathrm{t}, J=7.0,2 \mathrm{H})$, $1.62(\mathrm{p}, J=7.1,2 \mathrm{H}), 1.54(\mathrm{p}, J=7.0,2 \mathrm{H}), 1.26-1.36(\mathrm{~m}, 4 \mathrm{H}), 1.26(\mathrm{~s}$, $9 \mathrm{H}) ;{ }^{13} \mathrm{C} \delta$ 94.8, 80.2 , 75.0, 28.7, 28.5, 27.9, 26.5, 25.8, 20.9, -7.4; IR: 2977, 2937, 2860, 1362, 1197; HRMS (ESI ${ }^{+}$TOF) calcd for $\mathrm{C}_{12} \mathrm{H}_{21} \mathrm{INaO}_{2}[\mathrm{M}+\mathrm{Na}]^{+}$: 347.0484; found: 347.0485 .

\section{Synthesis of alkynyl peroxyacetals}

3-((2-Hydroperoxypropan-2-yl)oxy)-1-propyne(5) and 3-((2-((2hydroperoxypropan-2-yl)peroxy)propan-2-yl)oxy)-1-propyne (5a) were prepared using a procedure reported for unsaturated alcohols. ${ }^{19}$ To a solution of propargyl alcohol $(0.97 \mathrm{~mL}$, 16.9 mmol, 3 equiv.) in $\mathrm{CH}_{2} \mathrm{Cl}_{2}(50 \mathrm{~mL})$ was added 2,3-dimethyl2-butene $(0.65 \mathrm{~mL}, 5.47 \mathrm{mmol})$. This mixture was cooled to $-78{ }^{\circ} \mathrm{C}$ whereupon a gaseous stream of $\mathrm{O}_{3} / \mathrm{O}_{2}$ was admitted (pipette, $\sim 0.5-1 \mathrm{mmol} \mathrm{O}_{3} /$ minute). When the reaction was complete (TLC) introduction of $\mathrm{O}_{3} / \mathrm{O}_{2}$ was halted and $\mathrm{N}_{2}$ was briefly bubbled through the reaction mixture. The solution was carefully concentrated under reduced pressure (CAUTION) and the residue purified by column chromatography (5\% ether/ pentane) to yield $210.8 \mathrm{mg}$ (20\%) of hydroperoxyperoxide 5 a as a colorless oil, followed by traces of volatile hydroperoxyacetal 5. (CAUTION: the nearly $16 \%$ active oxygen content of hydroperoxyperoxide 5a suggests a moderate to high potential for exothermic decomposition.) As a result, this preparation was confined to $<20 \mathrm{mmol}$ scale and products were handled carefully (see general Discussion on safety, above). ${ }^{\mathbf{1 0 d}}$

5a: $R_{\mathrm{f}}=0.46(20 \% \mathrm{EA} / \mathrm{Hex}) ;{ }^{1} \mathrm{H} \delta 9.61(\mathrm{~s}, 1 \mathrm{H}), 4.31(\mathrm{t}, J=2.4$, $2 \mathrm{H}), 2.43(\mathrm{t}, J=2.3,1 \mathrm{H}), 1.51(\mathrm{~s}, 6 \mathrm{H}), 1.42(\mathrm{~s}, 6 \mathrm{H}) ;{ }^{13} \mathrm{C} \delta 109.4$, 106.8, 80.4, 74.3, 51.2, 23.5, 20.9; IR: 3362, 3286, 2999, 2946, 1369, 1176, 1034, 826, 620; HRMS (ESI ${ }^{+}$, TOF) calcd for $\mathrm{C}_{9} \mathrm{H}_{16} \mathrm{NaO}_{5}[\mathrm{M}+\mathrm{Na}]^{+}: 227.0895$; found: 227.0896 .

5: (trace byproduct; incompletely characterized as a colorless oil): $R_{\mathrm{f}}=0.43(20 \% \mathrm{EA} / \mathrm{Hex}) ;{ }^{1} \mathrm{H} \delta 9.88(\mathrm{~s}, 1 \mathrm{H}), 4.20(\mathrm{t}, J=2.4$, $2 \mathrm{H}), 2.45(\mathrm{t}, J=2.4,1 \mathrm{H}), 1.41(\mathrm{~s}, 6 \mathrm{H}) ;{ }^{13} \mathrm{C} \delta 105.9,81.3,73.7,49.9$, 22.7.

4-((2-Hydroperoxypropan-2-yl)oxy)-1-butyne (6) and 4-((2-((2hydroperoxypropan-2-yl)peroxy)propan-2-yl)oxy)-1-butyne (6a) were prepared using the same procedure described above. To 
a solution of 3-butyn-1-ol (1.97 mL, $26.0 \mathrm{mmol}, 2$ equiv.) in $\mathrm{CH}_{2} \mathrm{Cl}_{2}(125 \mathrm{~mL})$ was added 2,3-dimethyl-2-butene $(1.56 \mathrm{~mL}$, $13.1 \mathrm{mmol})$. This mixture was cooled to $-78{ }^{\circ} \mathrm{C}$ whereupon a gaseous stream of $\mathrm{O}_{3} / \mathrm{O}_{2}$ was admitted (approximately $1 \mathrm{mmol}$ $\mathrm{O}_{3} /$ minute). When the reaction as judged complete, by TLC, introduction of $\mathrm{O}_{3} / \mathrm{O}_{2}$ was halted and $\mathrm{N}_{2}$ was briefly bubbled through the reaction mixture. The solution was carefully concentrated under reduced pressure and the residue (CAUTION) purified by column chromatography (5\% ether/ pentane) to yield $455.6 \mathrm{mg}(24 \%)$ of 6 as an colorless oil, accompanied by $141.5 \mathrm{mg}$ (5\%) of $6 \mathrm{a}$. CAUTION: The products shown here are hydroperoxides or peroxy hydroperoxides with active oxygen contents suggesting a moderate to high potential for exothermic decomposition. These reactions were deliberately run on a modest scale and products should be handled carefully.

6a: $R_{\mathrm{f}}=0.46(20 \% \mathrm{EA} / \mathrm{Hex}) ;{ }^{1} \mathrm{H} \delta 9.75(\mathrm{~s}, 1 \mathrm{H}), 3.80(\mathrm{t}, J=9.6$, $2 \mathrm{H}), 2.59(\mathrm{td}, J=6.1, J=3.6,2 \mathrm{H}), 2.01(\mathrm{t}, J=3.6,1 \mathrm{H}), 1.53(\mathrm{~s}$, $6 \mathrm{H}), 1.47$ (s, 6H); ${ }^{13} \mathrm{C} \delta 109.4,106.8,80.4,74.3,51.2,23.5,20.9$; IR: 3293, 2997, 2946, 1367, 1196, 1177, 1141, 1045, 834, 636; HRMS (ESI ${ }^{+}$TOF) calcd for $\mathrm{C}_{9} \mathrm{H}_{16} \mathrm{NaO}_{5}[\mathrm{M}+\mathrm{Na}]^{+}$: 241.1052; found: 241.1052 .

6: $R_{\mathrm{f}}=0.53(20 \% \mathrm{EA} / \mathrm{Hex}) ;{ }^{1} \mathrm{H} \delta 8.46(\mathrm{~s}, 1 \mathrm{H}), 3.65(\mathrm{t}, J=5.4$, $2 \mathrm{H}), 2.50(\mathrm{td}, J=6.0, J=2.6,2 \mathrm{H}), 2.09(\mathrm{t}, J=2.6,1 \mathrm{H}), 1.49(\mathrm{~s}$, $6 \mathrm{H}) ;{ }^{13} \mathrm{C} \delta 105.7,83.7,69.8,60.0,22.6,20.5$; IR: 3427, 3287, 2995, 2947, 1367, 1201, 1158, 1051, 816, 639; HRMS (ESI ${ }^{+}$, TOF) calcd for $\mathrm{C}_{7} \mathrm{H}_{12} \mathrm{NaO}_{3}[\mathrm{M}+\mathrm{Na}]^{+}:$167.0684; found: 167.0681.

6-((2-Hydroperoxypropan-2-yl)oxy)-1-hexyne (7). By a similar procedure as described above, a mixture of 5-hexyn-1-ol (0.88 $\mathrm{mL}, 7.98 \mathrm{mmol}, 3$ equiv.) in $\mathrm{CH}_{2} \mathrm{Cl}_{2}(30 \mathrm{~mL})$ and 2,3-dimethyl-2butene $(0.32 \mathrm{~mL}, 2.69 \mathrm{mmol})$ were reacted with $\mathrm{O}_{3} / \mathrm{O}_{2}$ to generate, after careful concentration and chromatography $328.6 \mathrm{mg}(71 \%)$ of hydroperoxyacetal 7 as a colorless oil: $R_{\mathrm{f}}=$ 0.41 (20\% EA/Hex); ${ }^{1} \mathrm{H} \delta 7.89(\mathrm{~s}, 1 \mathrm{H}), 3.51(\mathrm{t}, J=6.5,2 \mathrm{H}), 2.22$ $(\mathrm{td}, J=6.7, J=2.6,2 \mathrm{H}), 1.95(\mathrm{t}, J=2.6,1 \mathrm{H}), 1.73-1.57(\mathrm{~m}, 4 \mathrm{H})$, $1.39(\mathrm{~s}, 6 \mathrm{H}) ;{ }^{13} \mathrm{C} \delta 105.3,84.5,68.7,61.2,29.1,25.3,22.8,18.3$; IR: 3296, 2993, 2943, 2872, 2117, 1740, 1366, 1199, 1151, 1061, 866, 629; HRMS (ESI ${ }^{+}$, TOF) calcd for $\mathrm{C}_{9} \mathrm{H}_{16} \mathrm{NaO}_{3}[\mathrm{M}+\mathrm{Na}]^{+}$: 195.0997; found: 195.0995.

4-((2-Methylperoxypropan-2-yl)oxy)-1-butyne (8) was prepared using an adaptation of a reported procedure. ${ }^{21,57}$ To a solution of hydroperoxyacetal 6 (359 mg, $2.49 \mathrm{mmol})$ in THF $(10 \mathrm{~mL})$ was added potassium tert-butoxide $(350 \mathrm{mg}, 3.12 \mathrm{mmol}$, 1.2 equiv.), followed by methyl iodide $(0.19 \mathrm{~mL}, 3.05 \mathrm{mmol}, 1.2$ equiv.). After the reaction had stirred at room temperature for 5 minutes, it was quenched with water $(10 \mathrm{~mL})$ and the resulting mixture extracted with ether $(15 \mathrm{~mL} \times 3)$. The combined organic layers were dried with $\mathrm{Na}_{2} \mathrm{SO}_{4}$ and concentrated under reduced pressure. The residue was purified by column chromatography (10\% ether/pentane) to yield $262.2 \mathrm{mg}(66 \%)$ of peroxyacetal 8 as a colorless oil: $R_{\mathrm{f}}=0.54(20 \% \mathrm{EA} / \mathrm{Hex}) ;{ }^{1} \mathrm{H}$ $\delta 3.85(\mathrm{~s}, 3 \mathrm{H}), 3.66(\mathrm{t}, J=9.8,2 \mathrm{H}), 2.47(\mathrm{td}, J=9.8, J=3.6,2 \mathrm{H})$, $1.97(\mathrm{t}, J=3.6,1 \mathrm{H}), 1.40(\mathrm{~s}, 6 \mathrm{H}) ;{ }^{13} \mathrm{C} \delta 104.9,81.5,69.4,63.4$, 60.2, 23.2, 20.3; IR: 2992, 2943, 2894, 1379, 1200, 1152, 1042, 864; HRMS (ESI ${ }^{+}$TOF) calcd for $\mathrm{C}_{8} \mathrm{H}_{14} \mathrm{NaO}_{3}[\mathrm{M}+\mathrm{Na}]^{+}$: 181.0814; found: 181.0841 .
6-((2-Methylperoxypropan-2-yl)oxy)-1-hexyne (9). By a similar procedure as described for above, a solution of hydroperoxyacetal 7 (146 mg, $0.85 \mathrm{mmol})$ in THF ( $5 \mathrm{~mL}$ ) was reacted with potassium tert-butoxide (114 mg, $1.02 \mathrm{mmol}, 1.2$ equiv.) and methyl iodide ( $0.10 \mathrm{~mL}, 1 \mathrm{mmol}, 1.2$ equiv.), to furnish, after purification, $142.5 \mathrm{mg}$ (90\%) of peroxyacetal 9 as an colorless oil: $R_{\mathrm{f}}=0.45(20 \% \mathrm{EA} / \mathrm{Hex}) ;{ }^{1} \mathrm{H} \delta 3.84(\mathrm{~s}, 3 \mathrm{H}), 3.53(\mathrm{t}, J$ $=8.3,2 \mathrm{H}), 2.23(\mathrm{td}, J=9.3, J=3.4,2 \mathrm{H}), 1.93(\mathrm{t}, J=3.1,1 \mathrm{H})$, 1.71-1.59 (m, 4H), $1.38(\mathrm{~s}, 6 \mathrm{H}) ;{ }^{13} \mathrm{C} \delta 104.7,84.6,68.4,63.3,61.0$, 29.1, 25.4, 23.5, 23.2, 18.3; IR: 3294, 2943, 2117, 1365, 1205, 1153, 1067, 1015, 869, 629; HRMS (ESI ${ }^{+}$TOF) calcd for $\mathrm{C}_{10} \mathrm{H}_{18} \mathrm{NaO}_{3}[\mathrm{M}+\mathrm{Na}]^{+}$: 209.1154; found: 209.1153.

1-Iodo-4-((2-methylperoxypropan-2-yl)oxy)-1-butyne (10). By a similar procedure as employed for synthesis of iodoalkynyl peroxide 3, reaction of peroxyacetal $8(141 \mathrm{mg}, 0.89 \mathrm{mmol})$ in $\mathrm{MeOH}$ (3 mL) with KI (183 mg, $1.10 \mathrm{mmol}, 1.2$ equiv.) followed by TBHP as an $\sim 5.5 \mathrm{M}$ solution in decane $(0.25 \mathrm{~mL}, 1.38 \mathrm{mmol}$, 1.2 equiv.) furnished, after concentration under reduced pressure. $206.7 \mathrm{mg}$ (81\%) of iodoalkynyl peroxyacetal 10 as a light yellow oil: $R_{\mathrm{f}}=0.54(10 \% \mathrm{EA} / \mathrm{Hex}) ;{ }^{1} \mathrm{H} \delta 3.85(\mathrm{~s}, 3 \mathrm{H}), 3.64(\mathrm{t}, J=$ $7.3,2 \mathrm{H}), 2.64(\mathrm{t}, J=7.4,2 \mathrm{H}), 1.39(\mathrm{~s}, 6 \mathrm{H}) ;{ }^{13} \mathrm{C} \delta 104.9,91.5,63.4$, 60.2, 23.2, 22.6, -5.4; IR: 2992, 2940, 2891, 1366, 1199, 1152, 1073, 1013, 862; HRMS (ESI ${ }^{+}$, TOF) calcd for $\mathrm{C}_{8} \mathrm{H}_{13} \mathrm{INaO}_{2}[\mathrm{M}+$ $\mathrm{Na}]^{+}:$306.9807; found: 306.9811 .

1-Iodo-6-((2-methylperoxypropan-2-yl)oxy)-1-hexyne (11). By a similar procedure as employed for synthesis of $\mathbf{3}$, reaction of peroxyacetal 9 (242 $\mathrm{mg}, 1.30 \mathrm{mmol})$ in $\mathrm{MeOH}(10 \mathrm{~mL})$ with $\mathrm{KI}$ (267 mg, $1.61 \mathrm{mmol}, 1.2$ equiv.) and TBHP as an $\sim 5.5 \mathrm{M}$ solution in decane (0.36 mL, $1.98 \mathrm{mmol}, 1.5$ equiv.) furnished iodoalkynyl peroxyacetal $11(400.8 \mathrm{mg}, 98 \%)$ of as a light yellow oil: $R_{\mathrm{f}}=0.49(10 \% \mathrm{EA} / \mathrm{Hex}) ;{ }^{1} \mathrm{H} \delta 3.85(\mathrm{~s}, 3 \mathrm{H}), 3.52(\mathrm{t}, J=6.5,2 \mathrm{H})$, $2.40(\mathrm{t}, J=6.8,2 \mathrm{H}), 1.69-1.54(\mathrm{~m}, 4 \mathrm{H}), 1.38(\mathrm{~s}, 6 \mathrm{H}) ;{ }^{13} \mathrm{C} \delta 104.7$, 94.7, 63.3 , 61.0 29.2 , 25.4, 23.2, 20.8, -7.1; IR: 3299, 2940, 1466, 1378, 1365, 1204, 1152, 1013, 858, 632; HRMS (ESI ${ }^{+}$, TOF) calcd for $\mathrm{C}_{10} \mathrm{H}_{17} \mathrm{INaO}_{2}[\mathrm{M}+\mathrm{Na}]^{+}$: 335.0120; found: 335.0126.

\section{Synthesis of peroxy azides}

1-Azido-(4-(tert-butylperoxy))butane (12). To a solution of 1bromo-4-chlorobutane $(2.57 \mathrm{~g}, 15.0 \mathrm{mmol})$ in DMF $(40 \mathrm{~mL})$ was added sodium azide (1.96 mg, $30.1 \mathrm{mmol}, 2$ equiv.). The reaction was stirred at room temperature for 24 hours. The reaction was diluted with $(20 \mathrm{~mL})$ water and extracted with hexanes $(15 \mathrm{~mL} \times 3)$. The combined organic layers were dried with $\mathrm{Na}_{2} \mathrm{SO}_{4}$ and the residue concentrated under reduced pressure to yield $1.8975 \mathrm{~g}$ (95\%) of 1-azido-4-chlorobutane as a colorless oil which was used without further purification: $R_{\mathrm{f}}=0.49(10 \% \mathrm{EA} /$ Hex). Spectral details matched those previously reported. ${ }^{22} R_{\mathrm{f}}=$ 0.49 (10\% EA/Hex).

A solution of the 1-azido-4-chlorobutane $(2.40 \mathrm{~g}, 18.0 \mathrm{mmol})$ and sodium iodide $(15.0 \mathrm{~g}, 100 \mathrm{mmol}, 5.5$ equiv.) was refluxed in acetone $(150 \mathrm{~mL})$ for 18 hours. The reaction was then diluted with water $(60 \mathrm{~mL})$ and extracted with hexanes $(50 \mathrm{~mL} \times 3)$. The combined organic layers were dried with $\mathrm{Na}_{2} \mathrm{SO}_{4}$ and the residue concentrated under reduced pressure to yield $3.6943 \mathrm{~g}$ (91\%) of 1-azido-4-iodobutane as an orange oil which was used without further purification. Spectral details matched those 
previously reported $.{ }^{22} R_{\mathrm{f}}=0.5(10 \% \mathrm{EA} / \mathrm{Hex}) ;{ }^{1} \mathrm{H} \delta 3.32(\mathrm{t}, J=6.6$, $2 \mathrm{H}), 3.20(\mathrm{t}, J=6.7,2 \mathrm{H}), 1.91$ (p, $J=7.4,2 \mathrm{H}), 1.71$ (p, $J=7.4$, $2 \mathrm{H}) ;{ }^{13} \mathrm{C} \delta 50.5,30.6,30.0,7.2$.

By a similar procedure as applied for synthesis of peroxide 1, reaction of $\mathrm{CsOH}$ monohydrate $(127 \mathrm{mg}, 0.85 \mathrm{mmol}, 1.2$ equiv.) in DMF $(12 \mathrm{~mL})$ at $0{ }^{\circ} \mathrm{C}$, TBHP as an $\sim 5.5 \mathrm{M}$ solution in decane $(0.19 \mathrm{~mL}, 1.05 \mathrm{mmol}, 1.5$ equiv., $\sim 5.5 \mathrm{M}$ solution in decane), and 1-azido-4-iodobutane (158 mg, $0.70 \mathrm{mmol}$ ) furnished, after purification by chromatography (5\% EA/Hex), $80.9 \mathrm{mg}(62 \%)$ of the azidobutyl $t$-butyl peroxide (12) as a colorless oil (CAUTION: low molecular weight azide/ peroxide): $R_{\mathrm{f}}=0.51(10 \% \mathrm{EA} / \mathrm{Hex}) ;{ }^{1} \mathrm{H} \delta 3.96(\mathrm{~m}, 2 \mathrm{H}), 3.30(\mathrm{t}$, $J=6.4,2 \mathrm{H}), 1.71-1.66(\mathrm{~m}, 4 \mathrm{H}), 1.24(\mathrm{~s}, 9 \mathrm{H}) ;{ }^{13} \mathrm{C} \delta 80.3,74.7$, 51.4, 26.5, 26.0, 25.4; IR: 2977, 2931, 2093, 1456, 1362, 1245, 1196, 881; HRMS (ESI ${ }^{+}$, TOF) calcd for $\mathrm{C}_{8} \mathrm{H}_{17} \mathrm{~N}_{3} \mathrm{NaO}_{2}[\mathrm{M}+\mathrm{Na}]^{+}$: 210.1218; found: 210.1213 .

((6-Azidohexan-2-yl)peroxy)triethylsilane (13). Into a $\mathrm{RBF}$ containing $\mathrm{CH}_{2} \mathrm{Cl}_{2}(300 \mathrm{~mL})$, were added sequentially iodine (7.61 g, $30.0 \mathrm{mmol}), \mathrm{PPh}_{3}(7.87 \mathrm{~g}, 30.0 \mathrm{mmol}$ ) and imidazole $(2.04 \mathrm{~g}, 30.0 \mathrm{mmol})$. The mixture was stirred for 15 minutes at $0{ }^{\circ} \mathrm{C}$, followed by the addition of 5 -hexenol $(2.50 \mathrm{~g}, 25.0 \mathrm{mmol})$. Reaction was stirred at room temperature and filtered through silica with hexanes $(600 \mathrm{~mL})$. The filtrate was concentrated under reduced pressure to yield $3.8557 \mathrm{~g}$ (75\%) of 6-iodohexene as a light orange oil which was used without further purification. Spectral details matched those previously reported $.^{58} R_{\mathrm{f}}=0.58(10 \% \mathrm{EA} / \mathrm{Hex}) ;{ }^{1} \mathrm{H} \delta 5.02(\mathrm{dq}, J=17.0, J=$ $1.8,1 \mathrm{H}), 4.96(\mathrm{ddt}, J=10.0,1.8,0.9,1 \mathrm{H}), 5.78(\mathrm{dddd}, J=17.2, J$ $=10.5, J=6.7, J=6.7,1 \mathrm{H}), 3.19(\mathrm{t}, J=7.0,2 \mathrm{H}), 2.08(\mathrm{q}, J=7.0$, $2 \mathrm{H}), 1.84(\mathrm{p}, J=7.5,2 \mathrm{H}), 1.50(\mathrm{p}, J=7.5,2 \mathrm{H}) ;{ }^{13} \mathrm{C} \delta 138.2$, 115.1, 33.0, 32.7, 29.8, 7.0.

To a solution of the iodohexene $(1.20 \mathrm{~g}, 5.71 \mathrm{mmol})$ in DMF $(20 \mathrm{~mL})$ was added sodium azide $(1.11 \mathrm{~g}, 17.1 \mathrm{mmol}, 3$ equiv.). The reaction was stirred at room temperature for 18 hours and then diluted with water $(10 \mathrm{~mL})$. The combined hexane extracts $(3 \times 15 \mathrm{~mL})$ were dried with $\mathrm{Na}_{2} \mathrm{SO}_{4}$ and the residue concentrated under reduced pressure to yield $688.5 \mathrm{mg}$ (98\%) of 6azido-hexene as a colorless oil which was used without further purification. Spectral details matched those previously reported: ${ }^{59} R_{\mathrm{f}}=0.59(10 \% \mathrm{EA} / \mathrm{Hex}) ;{ }^{1} \mathrm{H} \delta 5.01$ (dq, $J=17.2, J=1.6$, $1 \mathrm{H}), 4.97$ (d, $J=10.2,1 \mathrm{H}), 5.79$ (dddd, $J=17.0, J=10.5, J=6.7, J$ $=6.7,1 \mathrm{H}) 3.27(\mathrm{t}, J=6.8,2 \mathrm{H}), 2.09(\mathrm{q}, J=7.1,2 \mathrm{H}), 1.62(\mathrm{p}, J=$ 7.5, 2H), 1.48 (p, $J=7.6,2 \mathrm{H}) ;{ }^{13} \mathrm{C} \delta 138.3 \mathrm{a} 115.1,51.5,33.3,28.4$, 26.0.

To a solution of the azidohexene (113 $\mathrm{mg}, 0.90 \mathrm{mmol})$ in EtOH $(10 \mathrm{~mL})$ was added triethylsilane $(0.29 \mathrm{~mL}, 1.82 \mathrm{mmol}, 2$ equiv.), followed by $\mathrm{Co}(\mathrm{acac})_{2}$ (25.7 $\mathrm{mg}, 0.10 \mathrm{mmol}, 0.1$ equiv.). The reaction was stirred at room temperature under $\mathrm{O}_{2}$ for 18 hours. ${ }^{23}$ The solution was concentrated under reduced pressure and the residue purified by column chromatography (5\% EA/ Hex) to yield $114.0 \mathrm{mg}$ (46\%) of azido peroxide 13 as a colorless oil: $R_{\mathrm{f}}=0.5(10 \% \mathrm{EA} / \mathrm{Hex}) ;{ }^{1} \mathrm{H} \delta 4.01(\mathrm{~s}, J=5.8,1 \mathrm{H}), 3.27(\mathrm{t}, J$ $=6.9,2 \mathrm{H}), 1.61-1.40(\mathrm{~m}, 6 \mathrm{H}), 1.20(\mathrm{~d}, J=6.2,3 \mathrm{H}), 0.99(\mathrm{t}, J=$ 7.9, 9H), 0.69 (q, $J=8.0,6 \mathrm{H}) ;{ }^{13} \mathrm{C} \delta 81.2,51.5,34.0,29.1,22.8$, 18.5, 6.9, 3.9; IR; 2938, 2877, 2093, 1459, 1242, 1006, 796, 727; HRMS (ESI ${ }^{+}$, TOF) calcd for $\mathrm{C}_{12} \mathrm{H}_{27} \mathrm{~N}_{3} \mathrm{NaO}_{2} \mathrm{Si}[\mathrm{M}+\mathrm{Na}]^{+}$: 296.1770; found: 296.1772.

\section{Hexyne (14) was used as received}

Hex-5-yn-1-yl benzene (15) (100848-88-2). Alkyne 15 was prepared using a variant of a reported procedure. ${ }^{60}$ To a solution of ethynyl trimethylsilane (998.3 mg, $3.84 \mathrm{mmol})$ in THF $(10 \mathrm{~mL})$ was added $n$-BuLi (2.7 mL, $4.32 \mathrm{mmol}, 1.1$ equiv.) at $-78{ }^{\circ} \mathrm{C}$, followed by 4 -(iodobutyl)benzene (386.2 $\mathrm{mg}, 3.93 \mathrm{mmol}, 1.02$ equiv.). The reaction was allowed to warm to room temperature and stirred for 4 hours. The reaction was quenched with water $(30 \mathrm{~mL})$ and the combined ethyl acetate extracts $(3 \times 30 \mathrm{~mL})$ were dried with $\mathrm{Na}_{2} \mathrm{SO}_{4}$. Concentration under reduced pressure yielded $825.2 \mathrm{mg}$ (85\%) of trimethyl(6-phenylhex-1-yn-1-yl) silane (2253948-27-3) as a colorless oil which was used directly in the following reaction. $R_{\mathrm{f}}=0.60(10 \% \mathrm{EA} / \mathrm{Hex})$. Spectra details matched those in a literature report. ${ }^{61}$

To a solution of the crude alkynyl silane $(743.2 \mathrm{mg}, 3.09$ $\mathrm{mmol}$ ) in methanol $(25 \mathrm{~mL})$ was added potassium hydroxide (304.0 mg, $5.42 \mathrm{mmol}, 1.75$ equiv.). The reaction was stirred at room temperature for 2 hours. ${ }^{62}$ The reaction was quenched with water $(40 \mathrm{~mL})$ and extracted with hexanes $(30 \mathrm{~mL} \times 3)$. The combined organic layers were dried with $\mathrm{Na}_{2} \mathrm{SO}_{4}$, concentrated under reduced pressure and the residue purified by column chromatography (5\% EA/Hex) to yield $499.0 \mathrm{mg}$ (89\%) of the hex-5-yn-1-yl benzene as a colorless oil. Spectral details matched those previously reported: ${ }^{61,63} R_{\mathrm{f}}=0.65(10 \%$ EA/Hex); ${ }^{1} \mathrm{H} \delta 7.31(\mathrm{~m}, 2 \mathrm{H}), 7.24-7.21(\mathrm{~m}, 3 \mathrm{H}), 2.67(\mathrm{t}, J=7.9$, $2 \mathrm{H}), 2.25(\mathrm{td}, J=2.6, J=7.1,2 \mathrm{H}), 1.98(\mathrm{t}, J=2.6,1 \mathrm{H}), 1.78(\mathrm{p}, J$ $=7.8,2 \mathrm{H}), 1.61(\mathrm{p}, 7.5,2 \mathrm{H}) ;{ }^{13} \mathrm{C} \delta 142.4,128.5,128.4,125.9$, 84.5, 68.4, 35.5, 30.5, 28.1, 18.4; IR: 3305, 2927, 2854, 1495, 1453, 744, 696 .

3-Azidopropylbenzene (16). Iodine (11.74 g, $46.3 \mathrm{mmol})$, $\mathrm{PPh}_{3}$ (11.89 g, $45.3 \mathrm{mmol}$ ) and imidazole (3.16 g, $\left.46.4 \mathrm{mmol}\right)$ were sequentially added to a solution of $\mathrm{CH}_{2} \mathrm{Cl}_{2}(300 \mathrm{~mL})$. The mixture was stirred for 15 minutes at $0{ }^{\circ} \mathrm{C}$, whereupon 3-phenyl1-propanol (5.07 g, $37.2 \mathrm{mmol})$ was added. The reaction was stirred at room temperature for 5 hours and filtered through a $\sim 3^{\prime \prime}$ pad of silica with hexanes $(600 \mathrm{~mL})$. The filtrate was concentrated under reduced pressure to yield $9.05 \mathrm{~g}$ (98\%) of 3iodopropylbenzene as a light orange oil which was used without further purification. Spectral details matched those previously reported. ${ }^{64} R_{\mathrm{f}}: 0.50$ (10\% EA/Hex); ${ }^{1} \mathrm{H} \delta 7.33(\mathrm{t}, J=7.4,2 \mathrm{H}), 7.26$ $(\mathrm{t}, J=8.1,1 \mathrm{H}), 7.24(\mathrm{~d}, J=6.6,2 \mathrm{H}), 3.21(\mathrm{t}, J=6.8,2 \mathrm{H}), 2.77(\mathrm{t}, J$ $=7.3,2 \mathrm{H}), 2.17(\mathrm{p}, J=7.2,2 \mathrm{H}) ;{ }^{13} \mathrm{C} \delta 140.5,128.7,128.6,126.3$, 36.4, 35.0, 6.5.

To a solution of the iodopropyl benzene $(1.10 \mathrm{~g}, 4.48 \mathrm{mmol})$ in DMF $(20 \mathrm{~mL})$ was added sodium azide (875.6 g, $13.4 \mathrm{mmol}, 3$ equiv.). The reaction was stirred at room temperature for 18 hours. The reaction was diluted with water $(10 \mathrm{~mL})$ and extracted with $\mathrm{CH}_{2} \mathrm{Cl}_{2}(15 \mathrm{~mL} \times 3)$. The combined organic layers were dried with $\mathrm{Na}_{2} \mathrm{SO}_{4}$ and the residue concentrated under reduced pressure to yield $694.1 \mathrm{mg}$ (96\%) of 3-azidopropylbenzene as a colorless oil. Spectral details matched those previously reported. ${ }^{65} R_{\mathrm{f}}: 0.52(10 \% \mathrm{EA} / \mathrm{Hex}) ;{ }^{1} \mathrm{H} \delta 7.34(\mathrm{t}, J=7.4$, $2 \mathrm{H}), 7.26(\mathrm{t}, J=7.4,1 \mathrm{H}), 7.22(\mathrm{~d}, J=7.3,2 \mathrm{H}), 3.32(\mathrm{t}, J=6.8,2 \mathrm{H})$, $2.75(\mathrm{t}, J=7.5,2 \mathrm{H}), 1.95(\mathrm{p}, J=7.2,2 \mathrm{H}) ;{ }^{13} \mathrm{C} \delta 141.0,128.6$, 128.6, 126.3, 50.8, 32.9, 30.6. 
4-Azidobutylbenzene (17). Using a similar procedure as described above, reaction of a solution of iodine $(7.18 \mathrm{~g}, 28.3$ $\mathrm{mmol}), \mathrm{PPh}_{3}$ (7.40 g, $28.2 \mathrm{mmol}$ ), imidazole (1.91 g, $\left.28.1 \mathrm{mmol}\right)$ and 4-phenyl-1-butanol (3.47 g, $23.1 \mathrm{mmol})$ in $\mathrm{CH}_{2} \mathrm{Cl}_{2}(300 \mathrm{~mL})$ furnished $4.6282 \mathrm{~g}(77 \%)$ of 4 -iodobutylbenzene as a light orange oil. Spectral details matched those previously reported. ${ }^{66}$ $R_{\mathrm{f}}=0.51(10 \% \mathrm{EA} / \mathrm{Hex}) ;{ }^{1} \mathrm{H} \delta 7.32(\mathrm{dt}, J=5.4, J=1.5,2 \mathrm{H}), 7.24$ $(\mathrm{dt}, J=8.4,1.2,1 \mathrm{H}), 7.21(\mathrm{~d}, J=6.8,2 \mathrm{H}), 3.23(\mathrm{t}, J=6.8,2 \mathrm{H})$, $2.67(\mathrm{t}, J=7.6,2 \mathrm{H}), 1.89(\mathrm{~m}, 2 \mathrm{H}), 1.77(\mathrm{~m}, 2 \mathrm{H}) ;{ }^{13} \mathrm{C} \delta 141.9$, 128.5, 126.0, 34.9, 33.1, 32.3, 6.9.

Using a similar procedure as described above, reaction of the 4-iodobutylbenzene $(1.25 \mathrm{~g}, 4.81 \mathrm{mmol})$ with sodium azide (969 mg, 14.9 mmol, 3 equiv.) in DMF (20 mL) furnished $811.7 \mathrm{mg}$ (97\%) of 4-azidobutylbenzene (17) as a colorless oil. Spectral details matched those previously reported. ${ }^{66} R_{\mathrm{f}}=0.53(10 \% \mathrm{EA} / \mathrm{Hex}) ;{ }^{1} \mathrm{H}$ $\delta 7.32(\mathrm{t}, J=7.3,2 \mathrm{H}), 7.22(\mathrm{t}, J=7.3,1 \mathrm{H}), 7.21(\mathrm{~d}, J=7.3,2 \mathrm{H}), 3.31$ $(\mathrm{t}, J=6.5,2 \mathrm{H}), 2.68(\mathrm{t}, J=7.6,2 \mathrm{H}), 1.75(\mathrm{~m}, 2 \mathrm{H}), 1.67(\mathrm{~m}, 2 \mathrm{H}) ;{ }^{13} \mathrm{C}$ $\delta 142.0,128.5,128.5,126.0,51.5,35.5,28.6$.

6-Azidohexane-1-thiol (18). This molecule, which is commercially available, has been previously described without characterization. ${ }^{67}$

Synthesis of $S$-(6-hydroxyhexyl)ethanethioate was adapted from a reported procedure. ${ }^{67}$ To a solution of 6-bromohexanol $(3.07 \mathrm{~g}, 17.0 \mathrm{mmol})$ in acetone $(175 \mathrm{~mL})$ was added potassium thioacetate (3.92 g, $34.3 \mathrm{mmol}, 2$ equiv.). The reaction was stirred at $40{ }^{\circ} \mathrm{C}$ for 18 hours. The reaction was then quenched with $1 \mathrm{M} \mathrm{NaHCO}_{3}(50 \mathrm{~mL})$ and the mixture extracted with ether $(50 \mathrm{~mL} \times 3)$. The combined organic layers were dried with $\mathrm{Na}_{2} \mathrm{SO}_{4}$, concentrated under reduced pressure, and the residue was purified by column chromatography (5-20\% ether/pentane) to yield $1.89 \mathrm{~g}(63 \%)$ of the thioester as a red oil. Spectral details matched those previously reported. ${ }^{68} R_{\mathrm{f}}=0.30$ (30\% EA/Hex); ${ }^{1} \mathrm{H} \delta 3.62(\mathrm{t}, J=6.4,2 \mathrm{H}), 2.86(\mathrm{t}, J=6.8,2 \mathrm{H}), 2.31(\mathrm{~s}, 3 \mathrm{H})$, 1.53-1.62 (m, 4H), 1.35-1.43 (m, 4H); ${ }^{13} \mathrm{C} \delta$ 196.2, 62.9, 32.7, 30.8, 29.6, 29.1, 28.6, 25.3; IR: 3292, 2944, 1380, 1205, 1157, 1064, 831, 630 .

The following reagents were sequentially added to $\mathrm{CH}_{2} \mathrm{Cl}_{2}$ (300 mL): iodine (2.86 g, $11.3 \mathrm{mmol}, 1.2$ equiv.), $\mathrm{PPh}_{3}$ (2.96 g, $11.3 \mathrm{mmol}, 1.2$ equiv.) and imidazole (769.3 $\mathrm{mg}, 11.3 \mathrm{mmol}, 1.2$ equiv.). The mixture was stirred for 15 minutes at $0{ }^{\circ} \mathrm{C}$, whereupon $S$-(6-hydroxyhexyl)ethanethioate $(1.66 \mathrm{~g}, 9.42 \mathrm{mmol})$ was added. The reaction was stirred at room temperature for 5 hours and filtered through a $7.5 \mathrm{~cm}$ pad of silica with hexanes (600 $\mathrm{mL}$ ). The filtrate was concentrated under reduced pressure to yield $1.98 \mathrm{~g}$ (73\%) of $S$-(6-iodohexyl)ethanethioate as a brown oil which was used directly for the next reaction: $R_{\mathrm{f}}=0.40(5 \% \mathrm{EA} /$ Hex); ${ }^{1} \mathrm{H} \delta 3.20(\mathrm{t}, J=7.0,2 \mathrm{H}), 2.89(\mathrm{t}, J=7.3,2 \mathrm{H}), 2.35(\mathrm{~s}, 3 \mathrm{H})$, $1.84(\mathrm{p}, J=6.8,2 \mathrm{H}), 1.61(\mathrm{p}, J=6.9,2 \mathrm{H}), 1.37-1.47(\mathrm{~m}, 4 \mathrm{H}) ;{ }^{13} \mathrm{C}$ $\delta$ 196.1, 33.4, 30.8, 30.1, 29.4, 29.1, 27.8, 7.0; IR: 2929, 1686, 1132, 954, 623; HRMS (ESI ${ }^{+}$, TOF) calcd for $\mathrm{C}_{8} \mathrm{H}_{15} \mathrm{IOS}[\mathrm{M}]^{+}$: 285.9888; found: 285.9898 .

To a solution of $S$-(6-azidohexyl)ethanethioate $(1.16 \mathrm{~g}, 4.05$ $\mathrm{mmol})$ in DMF $(20 \mathrm{~mL})$ was added sodium azide $(1.45 \mathrm{~g}$, 22.3 mmol, 5.5 equiv.). The reaction was stirred at room temperature for 18 hours. The reaction was diluted with water $(10 \mathrm{~mL})$ and extracted with $\mathrm{CH}_{2} \mathrm{Cl}_{2}(15 \mathrm{~mL} \times 3)$. The combined organic layers were dried with $\mathrm{Na}_{2} \mathrm{SO}_{4}$ and the residue concentrated under reduced pressure to yield $762.6 \mathrm{mg}$ (94\%) of azido/ethioester as an orange oil which was used without further purification. Spectral details matched those previously reported. ${ }^{69} R_{\mathrm{f}}=0.32(5 \% \mathrm{EA} / \mathrm{Hex}) ;{ }^{1} \mathrm{H} \delta 3.25(\mathrm{t}, J=7.1,2 \mathrm{H}), 2.86$ $(\mathrm{t}, J=7.1,2 \mathrm{H}), 2.32(\mathrm{~s}, 3 \mathrm{H}), 1.54-1.61(\mathrm{~m}, 4 \mathrm{H}), 1.37-1.40(\mathrm{~m}$, $4 \mathrm{H}) ;{ }^{13} \mathrm{C} \delta 196.0,51.5,30.8,29.5,29.0,28.8,28.4,26.3$; IR: 2933, 2090, 1688, 1256, 1132, 951, 624 .

The deblocking of the thioacetate employed a procedure reported for a nine-carbon homolog. ${ }^{70}$ To a solution of $S$-(6azidohexyl)ethanethioate $(762.6 \mathrm{~g}, 3.79 \mathrm{mmol})$ in $\mathrm{MeOH}(70 \mathrm{~mL})$ was added conc. aq. $\mathrm{HCl}(4.0 \mathrm{~mL})$. The reaction was stirred at reflux for 3 hours and then allowed to cool. The reaction was diluted with water $(20 \mathrm{~mL})$ and extracted with diethyl ether $(25 \mathrm{~mL} \times 3)$. The combined organic layers were dried with $\mathrm{Na}_{2} \mathrm{SO}_{4}$ and the residue concentrated under reduced pressure to yield $559.8 \mathrm{mg}$ (93\%) of 6-azidohexane-1-thiol as a strongsmelling orange oil. $R_{\mathrm{f}}=0.35(5 \% \mathrm{EA} / \mathrm{Hex}) ;{ }^{1} \mathrm{H} \delta 3.27(\mathrm{t}, J=$ $6.6,2 \mathrm{H}), 2.53(\mathrm{q}, J=7.2,2 \mathrm{H}), 1.57-1.64(\mathrm{~m}, 4 \mathrm{H}), 1.37-1.43(\mathrm{~m}$, 4H); IR: 3930, 3857, $2400(\mathrm{w}) ; 2086(\mathrm{~s}) ; 1454,1253 ;{ }^{13} \mathrm{C} \delta 51.5$, 33.9, 28.9, 28.0, 26.3, 24.6 IR: 2930, 2087, 1254; HRMS (ESI ${ }^{+}$, TOF) calcd for $\mathrm{C}_{6} \mathrm{H}_{13} \mathrm{~N}_{3} \mathrm{~S}[\mathrm{M}]^{+}$: 159.0830; found: 159.0867, 316.1512 (disulfide).

\section{General procedure for click reactions}

Click reactions were conducted based upon adaptations of a reported procedure. ${ }^{25 b}$

General procedure for click reactions with $\mathrm{CuI}$. To a solution of alkyne ( 1 equiv.) and azide ( 1 equiv.) in THF was added $\mathrm{CuI}$ ( 0.2 equiv.), followed by triethylamine ( 3 equiv.). The reaction was stirred at room temperature for 3 hours, then diluted with water and extracted with ethyl acetate $(\times 3)$. The combined organic layers were dried with $\mathrm{Na}_{2} \mathrm{SO}_{4}$, concentrated under reduced pressure and the residue purified by column chromatography.

General procedure for click reactions with $\mathrm{CuSO}_{4}$. To a solution of alkyne ( 1 equiv.) and azide 16 ( 1 equiv.) in $\mathrm{CH}_{2} \mathrm{Cl}_{2}$ was added an aqueous solution containing $\mathrm{CuSO}_{4}$ (0.2 equiv.) and sodium ascorbate ( 0.2 equiv.). After stirring at $\mathrm{rt}$ for $3 \mathrm{~h}$, the reaction was diluted with water and extracted with ethyl acetate $(\times 3)$. The combined organic layers were dried with $\mathrm{Na}_{2} \mathrm{SO}_{4}$, concentrated under reduced pressure and the residue purified by column chromatography.

4-(4-(tert-Butylperoxy)butyl)-1-(3-phenylpropyl)-1H-1,2,3-triazole (19). To a solution of peroxyhexyne 1 (203 $\mathrm{mg}, 1.19 \mathrm{mmol})$ and azide 16 (193 mg, $1.20 \mathrm{mmol}$ ) in THF ( $5 \mathrm{~mL}$ ) was added $\mathrm{CuI}$ (47.6 mg, $0.25 \mathrm{mmol}, 0.2$ equiv.), ${ }^{25 b}$ followed by triethylamine (0.50 mL, $3.6 \mathrm{mmol}, 3$ equiv.) and triethylsilane $(0.21 \mathrm{~mL}$, $1.3 \mathrm{mmol}, 1.1$ equiv.). The reaction was stirred at room temperature for 24 hours. The reaction was diluted with water $(10 \mathrm{~mL})$ and extracted with EA $(15 \mathrm{~mL} \times 3)$. The combined organic layers were dried with $\mathrm{Na}_{2} \mathrm{SO}_{4}$, concentrated under reduced pressure and the residue purified by column chromatography (10\% EA/Hex) to yield $156.2 \mathrm{mg}$ (38\%) of triazole 19 as a yellow oil: $R_{\mathrm{f}}=0.28(40 \% \mathrm{EA} / \mathrm{Hex}) ;{ }^{1} \mathrm{H} \delta 7.29(\mathrm{t}, J=7.4,2 \mathrm{H})$, $7.26(\mathrm{~s}, 1 \mathrm{H}), 7.23(\mathrm{t}, J=7.4,1 \mathrm{H}), 7.19(\mathrm{~d}, J=7.1,2 \mathrm{H}), 4.33(\mathrm{t}, J=$ 
7.1, 2H), $3.99(\mathrm{t}, J=6.3,2 \mathrm{H}), 2.77(\mathrm{t}, J=7.4,2 \mathrm{H}), 2.67(\mathrm{t}, J=7.5$, $2 \mathrm{H}), 2.25(\mathrm{p}, J=7.3,2 \mathrm{H}), 1.78(\mathrm{~m}, 2 \mathrm{H}), 1.69(\mathrm{~m}, 2 \mathrm{H}), 1.25(\mathrm{~s}, 9 \mathrm{H})$; ${ }^{13} \mathrm{C} \delta$ 148.0, 140.4, 128.7, 128.5, 126.4, 120.7, 80.2, 74.8, 49.5, 32.7, 31.8, 27.6, 26.5, 26.2, 25.6; IR: 2976, 2932, 2866, 1497, 1454, 1362, 1196, 1046, 878, 746, 670, 493; HRMS (ESI $\left.{ }^{+}, \mathrm{TOF}\right)$ calcd for $\mathrm{C}_{19} \mathrm{H}_{29} \mathrm{~N}_{3} \mathrm{NaO}_{2}[\mathrm{M}+\mathrm{Na}]^{+}$: 354.2157; found: 354.2155.

4-(4-(tert-Butylperoxy)butyl)-1-(4-phenylbutyl)-1H-1,2,3-triazole (20) and 4-(4-(tert-butylperoxy)butyl)-5-iodo-1-(4-phenylbutyl)-1H-1,2,3-triazole (20i). To a solution of 6-(tertbutylperoxy)-1-hexyne (238 $\mathrm{mg}, 1.40 \mathrm{mmol}$ ) and 4-azidobutylbenzene (209 mg, $1.19 \mathrm{mmol}$ ) in THF ( $5 \mathrm{~mL}$ ) was added $\mathrm{CuI}$ ( $47.6 \mathrm{mg}, 0.25 \mathrm{mmol}, 0.2$ equiv.), followed by triethylamine ( 0.60 $\mathrm{mL}, 4.29$ mmol, 3 equiv.). ${ }^{46}$ The reaction was stirred at room temperature for 1 hour. The reaction was diluted with water (10 $\mathrm{mL})$ and extracted with $\mathrm{EA}(15 \mathrm{~mL} \times 3)$. The combined organic layers were dried with $\mathrm{Na}_{2} \mathrm{SO}_{4}$, concentrated under reduced pressure and the residue purified by column chromatography (10\% EA/Hex) to yield $154.4 \mathrm{mg}$ (37\%) of triazole 20 as a yellow oil. Reactions conducted in the presence of $\mathrm{CuI}$ often contained traces of the corresponding 5-iodotriazole (20i).

20: $R_{\mathrm{f}}=0.27(40 \% \mathrm{EA} / \mathrm{Hex}) ;{ }^{1} \mathrm{H} \delta 7.29(\mathrm{t}, J=7.4,2 \mathrm{H}), 7.24(\mathrm{~s}$, $1 \mathrm{H}), 7.21(\mathrm{t}, J=7.4,1 \mathrm{H}), 7.16(\mathrm{~d}, J=7.2,2 \mathrm{H}), 4.33(\mathrm{t}, J=7.2,2 \mathrm{H})$, $3.98(\mathrm{t}, J=6.1,2 \mathrm{H}), 2.75(\mathrm{t}, J=7.2,2 \mathrm{H}), 2.66(\mathrm{t}, J=7.5,2 \mathrm{H}), 1.93$ $(\mathrm{p}, J=7.5,2 \mathrm{H}), 1.80-1.62(\mathrm{~m}, 6 \mathrm{H}), 1.25(\mathrm{~s}, 9 \mathrm{H}) ;{ }^{13} \mathrm{C} \delta 150.0$, 141.6, 128.5, 128.5, 126.1, 120.6, 80.2, 74.8, 50.1, 35.3, 29.9, 28.3, 27.6, 26.4, 26.2, 25.6 ppm; IR: 3026, 2934, 1454, 1362, 1196, 1044, 747, 699; HRMS (ESI ${ }^{+}$, TOF) calcd for $\mathrm{C}_{20} \mathrm{H}_{31} \mathrm{~N}_{3} \mathrm{NaO}_{2}[\mathrm{M}+$ $\mathrm{Na}]^{+}:$368.2314; found: 368.2312 .

20i: $R_{\mathrm{f}}=0.31(40 \% \mathrm{EA} / \mathrm{Hex}) ;{ }^{1} \mathrm{H} \delta 7.21(\mathrm{t}, J=7.2,2 \mathrm{H}), 7.18(\mathrm{~m}$, $3 \mathrm{H}), 4.37(\mathrm{t}, J=7.2,2 \mathrm{H}), 3.99(\mathrm{t}, J=6.4,2 \mathrm{H}), 2.70(\mathrm{t}, J=7.2,2 \mathrm{H})$, $2.68(\mathrm{t}, J \sim 7,2 \mathrm{H}), 1.95(\mathrm{p}, J=7.2,2 \mathrm{H}), 1.80(\mathrm{~m}, 2 \mathrm{H}), 1.76(\mathrm{~m}$, $4 \mathrm{H}), 1.25(\mathrm{~s}, 9 \mathrm{H}) ;{ }^{13} \mathrm{C} \delta 151.60,141.7,128.58,128.55,126.1$, 120.6, 80.3, 78.1, 74.8, 50.6, 35.3, 29.5, 28.2, 27.6, 26.4, 26.1, 25.8 ppm; IR: 2976, 2936, 1454, 1362, 1197, 1044, 743, 699; HRMS (ESI ${ }^{+}$, TOF) calcd for $\mathrm{C}_{20} \mathrm{H}_{30} \mathrm{IN}_{3} \mathrm{NaO}_{2}[\mathrm{M}+\mathrm{Na}]^{+}$: 494.1280 ; found: 494.1276 .

4-(1-(4-Phenylbutyl)-1H-1,2,3-triazol-4-yl)butanal (21). This colorless oil, which coelutes with the parent peroxide, was a minor byproduct in many of the click reactions but became a major byproduct for reactions conducted for long periods or when the peroxy triazole products were resubjected to reaction conditions: $R_{\mathrm{f}}=0.27(40 \% \mathrm{EA} / \mathrm{Hex}) ;{ }^{1} \mathrm{H} \delta 9.79(\mathrm{t}, J=0.7,1 \mathrm{H})$, $7.32-7.16(\mathrm{~m}, 6 \mathrm{H}), 4.34(\mathrm{t}, J=7.2,2 \mathrm{H}), 2.78(\mathrm{t}, J=7.4,2 \mathrm{H}), 2.68$ $(\mathrm{t}, J=7.5,2 \mathrm{H}), 2.55(\mathrm{td}, J=1.4, J=7.3,2 \mathrm{H}), 2.04(\mathrm{p}, J=7.3,2 \mathrm{H})$, $1.94(\mathrm{p}, J=7.6,2 \mathrm{H}), 1.67(\mathrm{~m}, 2 \mathrm{H}) ;{ }^{13} \mathrm{C}(176 \mathrm{MHz}) \delta 202.2,147.2$, 141.6, 128.6, 128.5, 126.2 , 120.8, 50.2, 43.3, 35.3, 32.1, 28.3, 27.2, 21.9; IR: 3135, 3025, 2925, 2723, 1722, 1454, 1275, 748, 701; HRMS (ESI ${ }^{+}$, TOF) calcd for $\mathrm{C}_{20} \mathrm{H}_{31} \mathrm{~N}_{3} \mathrm{NaO}_{2}[\mathrm{M}+\mathrm{Na}]^{+}$: 294.1582; found: 294.1588 .

\section{Stability of peroxyalkyne towards CuI}

To 6-(tert-butylperoxy)-1-hexyne 1 (170 mg, $1.0 \mathrm{mmol}$ ) in THF (5 $\mathrm{mL}$ ) was added $\mathrm{CuI}$ (38 mg, $0.20 \mathrm{mmol}, 0.2$ equiv.). The reaction was stirred at room temperature for 24 hours. The reaction was quenched with water and extracted with ethyl acetate $(15 \mathrm{~mL} \times$ 3). The combined organic layers were dried with $\mathrm{Na}_{2} \mathrm{SO}_{4}$, concentrated under reduced pressure to yield $153.4 \mathrm{mg}(90 \%)$ of recovered starting material as a colorless oil: $R_{\mathrm{f}}=0.55(10 \% \mathrm{EA} /$ Hex).

\section{Reactions in the presence of TBTA}

CuSO $_{4}$. To 6-(tert-butylperoxy)-1-hexyne 1 (272 mg, $1.6 \mathrm{mmol}$ ) and 4-phenyl-butyl-azide 17 (228 mg, $1.3 \mathrm{mmol})$ in $1: 1 \mathrm{DMSO} /$ water $(10 \mathrm{~mL})$ was added $\mathrm{CuSO}_{4}(25.5 \mathrm{mg}, 0.16 \mathrm{mmol}, 0.1$ equiv.), sodium ascorbate ( $47.5 \mathrm{mg}, 0.24 \mathrm{mmol}, 0.15$ equiv.), and TBTA ( $8.4 \mathrm{mg}, 0.016 \mathrm{mmol}, 0.01$ equiv.). The reaction was stirred at room temperature for 1.5 hours. The reaction was quenched with water and extracted with ethyl acetate $(15 \mathrm{~mL} \times$ 3). The combined organic layers were dried with $\mathrm{Na}_{2} \mathrm{SO}_{4}$, concentrated under reduced pressure and purified by column chromatography (10\% EA/Hex) to yield $89.9 \mathrm{mg}$ (20\%) of triazole 20 as a yellow oil: $R_{\mathrm{f}}=0.28(40 \% \mathrm{EA} / \mathrm{Hex})$.

CuI. To 6-(tert-butylperoxy)-1-hexyne 1 (238 mg, $1.4 \mathrm{mmol})$ and azide 17 (245 mg, $1.4 \mathrm{mmol}$ ) in DMSO : water ( $2.5 \mathrm{~mL}: 2.5$ $\mathrm{mL}$ ) was added CuI (57 mg, $0.30 \mathrm{mmol}, 0.2$ equiv.) and triethylamine (0.6 mL, $4.2 \mathrm{mmol}, 3$ equiv.), followed by TBTA (7.4 $\mathrm{mg}, 0.014 \mathrm{mmol}, 0.01$ equiv.). The reaction was stirred at room temperature for 3 hours. The reaction was quenched with water and extracted with ethyl acetate $(15 \mathrm{~mL} \times 3)$. The combined organic layers were dried with $\mathrm{Na}_{2} \mathrm{SO}_{4}$, concentrated under reduced pressure and purified by column chromatography (10\% EA/Hex) to yield $166.3 \mathrm{mg}(35 \%)$ of triazole 20 as a yellow oil: $R_{\mathrm{f}}=0.28(40 \% \mathrm{EA} / \mathrm{Hex})$.

\section{Reaction of iodoalkyne}

4-(4-(tert-Butylperoxy)butyl)-5-iodo-1-(3-phenylpropyl)-1H1,2,3-triazole (19i). To a solution of 1-iodo-6-tert-butylperoxy hexyne 3 (118 $\mathrm{mg}, 0.40 \mathrm{mmol}$ ) and 3-azidopropylbenzene 16 (64.5 mg, $0.41 \mathrm{mmol})$ in THF $(3.5 \mathrm{~mL})$ was added CuI $(7.6 \mathrm{mg}$, $0.04 \mathrm{mmol}, 0.1$ equiv.), followed by triethylamine $(0.12 \mathrm{~mL}$, 0.86 mmol, 2 equiv.). ${ }^{12}$ The reaction was stirred at room temperature for 24 hours. The reaction was diluted with water $(10 \mathrm{~mL})$ and extracted with EA $(15 \mathrm{~mL} \times 3)$. The combined organic layers were dried with $\mathrm{Na}_{2} \mathrm{SO}_{4}$, concentrated under reduced pressure and the residue purified by column chromatography (10\% EA/Hex) to yield $116.4 \mathrm{mg}$ (64\%) of iodotetrazole $19 \mathrm{i}$ as a yellow oil: $R_{\mathrm{f}}=0.36(20 \% \mathrm{EA} / \mathrm{Hex}) ;{ }^{1} \mathrm{H} \delta 7.32(\mathrm{t}, J=7.5$, $2 \mathrm{H}), 7.24(\mathrm{t}, J=7.5,1 \mathrm{H}), 7.22(\mathrm{~d}, J=7.6,2 \mathrm{H}), 4.37(\mathrm{t}, J=7.3,2 \mathrm{H})$, $3.99(\mathrm{t}, J=6.4,2 \mathrm{H}), 2.70(\mathrm{td}, J=7.5, J=3.4,4 \mathrm{H}), 2.25(\mathrm{p}, J=7.4$, $2 \mathrm{H}), 1.80(\mathrm{p}, J=7.6,2 \mathrm{H}), 1.68(\mathrm{p}, J=6.3,2 \mathrm{H}), 1.25(\mathrm{~s}, 9 \mathrm{H}) ;{ }^{13} \mathrm{C}$ $\delta$ 151.6, 140.4, 128.7, 128.6, 126.4, 80.2, 78.1, 74.7, 50.1, 32.6, 31.3, 27.6, 26.5, 26.0, 25.8; IR: 3031, 2936, 2098, 1461, 1361, 1196 1022, 880, 752, 699, 509; HRMS (ESI ${ }^{+}$, TOF) calcd for $\mathrm{C}_{19^{-}}$ $\mathrm{H}_{28} \mathrm{IN}_{3} \mathrm{NaO}_{2}[\mathrm{M}+\mathrm{Na}]^{+}$: 480.1124; found: 480.1126 .

\section{Competition of iodoalkynyl peroxide with simple alkyne}

To a solution of 6-(tert-butylperoxy)-1-iodohexyne 3 (0.5 $\mathrm{mmol})$, 5-hexyn-1-ol (0.5 mmol) and 3-phenylpropyl azide 16 (0.5 $\mathrm{mmol})$ in THF ( $5 \mathrm{~mL}$ ) was added CuI ( $0.050 \mathrm{mmol}, 0.1$ equiv.), followed by triethylamine ( $1.0 \mathrm{mmol}, 2$ equiv.). The reaction was stirred at room temperature for 18 hours. The reaction was quenched with water and extracted with ethyl acetate $(15 \mathrm{~mL} \times 3)$. The 
combined organic layers were dried with $\mathrm{Na}_{2} \mathrm{SO}_{4}$, concentrated under reduced pressure and purified by column chromatography (10\% EA/Hex) to yield $64.5 \mathrm{mg}(29 \%)$ of 4 -(4-(tert-butylperoxy)butyl)-5-iodo-1-(3-phenylpropyl)-1H-1,2,3-triazole

(19i) as a yellow oil.

4-(6-(tert-Butylperoxy)hexyl)-1-(3-phenylpropyl)-1H-1,2,3-triazole (6/3) (22) and 4-(6-(tert-butylperoxy)hexyl)-5-iodo-1-(3phenylpropyl)-1H-1,2,3-triazole and 6-(1-(3-phenylpropyl)- $1 \mathrm{H}$ 1,2,3-triazol-4-yl)hexanal (24). To a solution of 8-(tertbutylperoxy)-1-octyne $2(304.1 \mathrm{mg}, 1.53 \mathrm{mmol})$ and 3-azidopropylbenzene 16 (268.4 mg, $1.66 \mathrm{mmol}, 1.1$ equiv.) in THF (6 mL) was added $\mathrm{CuI}(64.8 \mathrm{mg}, 0.25 \mathrm{mmol}, 0.2$ equiv.), followed by triethylamine $\left(0.65 \mathrm{~mL}, 4.66 \mathrm{mmol}, 3\right.$ equiv.). ${ }^{3}$ The reaction was stirred at room temperature for 3 hours. The reaction was diluted with water $(10 \mathrm{~mL})$ and extracted with $\mathrm{EA}(15 \mathrm{~mL} \times 3)$. The combined organic layers were dried with $\mathrm{Na}_{2} \mathrm{SO}_{4}$, concentrated under reduced pressure and the residue purified by column chromatography (10\% EA/Hex) to yield $374.3 \mathrm{mg}(68 \%)$ of peroxy triazole $22,45.9 \mathrm{mg}(6 \%)$ of iodotriazole $22 \mathrm{i}$ and $47.1 \mathrm{mg}(11 \%)$ of aldehyde 24 .

22: $R_{\mathrm{f}}: 0.28(40 \% \mathrm{EA} / \mathrm{Hex}) ;{ }^{1} \mathrm{H} \delta 7.31(\mathrm{t}, J=7.5,2 \mathrm{H}), 7.24(\mathrm{~s}$, $1 \mathrm{H}), 7.22(\mathrm{t}, J=7.6,1 \mathrm{H}), 7.19(\mathrm{~d}, J=7.4,2 \mathrm{H}), 4.33(\mathrm{t}, J=7.1,2 \mathrm{H})$, $3.94(\mathrm{t}, J=6.5,2 \mathrm{H}), 2.73(\mathrm{t}, J=7.6,2 \mathrm{H}), 2.66(\mathrm{t}, J=7.5,2 \mathrm{H}), 2.25$ (p, $J=7.3,2 \mathrm{H}), 1.69$ (p, $J=7.4,2 \mathrm{H}), 1.61(\mathrm{p}, J=6.8,2 \mathrm{H}), 1.36-1.45$ (m, 4H), 1.25 (s, 9H); ${ }^{13} \mathrm{C} \delta$ 148.4, 140.4, 128.7, 128.5, 126.4, 120.6, 80.2, 75.1, 49.4, 32.7, 31.8, 29.5, 29.2, 27.9, 26.5, 26.1, 25.7; IR: 2976, 2933, 2859, 1454, 1361, 1197, 1047; HRMS (ESI ${ }^{+}$, TOF) calcd for $\mathrm{C}_{21} \mathrm{H}_{33} \mathrm{~N}_{3} \mathrm{NaO}_{2}[\mathrm{M}+\mathrm{Na}]^{+}: 382.2470$; found: 382.2467 .

22i: $R_{\mathrm{f}}: 0.32(40 \% \mathrm{EA} / \mathrm{Hex}) ;{ }^{1} \mathrm{H} \delta 7.31(\mathrm{t}, J=7.3,2 \mathrm{H}), 7.21-7.24$ $(\mathrm{m}, 3 \mathrm{H}), 4.36(\mathrm{t}, J=7.2,2 \mathrm{H}), 3.94(\mathrm{t}, J=6.6,2 \mathrm{H}), 2.68(\operatorname{app~p}, J=$ $8.1, J=7.6,4 \mathrm{H}), 2.25$ (p, $J=7.2,2 \mathrm{H}), 1.71(\mathrm{p}, J=7.1,2 \mathrm{H}), 1.61$ (p, $J=6.6,2 \mathrm{H}), 1.40-1.41(\mathrm{~m}, 4 \mathrm{H}), 1.25(\mathrm{~s}, 9 \mathrm{H}) ;{ }^{13} \mathrm{C} \delta 151.9$, 140.4, 128.7, 128.6, 126.4, 80.1, 78.0, 75.1, 50.1, 32.6, 31.3, 29.1, 29.0, 27.9, 26.5, 26.1, 26.1; IR: 2974, 2934, 2861, 1453, 1362; HRMS (ESI ${ }^{+}$, TOF) calcd for $\mathrm{C}_{21} \mathrm{H}_{32} \mathrm{IN}_{3} \mathrm{NaO}_{2}[\mathrm{M}+\mathrm{Na}]^{+}$: 508.1437; found: 508.1423.

24: $R_{\mathrm{f}}: 0.27(40 \% \mathrm{EA} / \mathrm{Hex}) ;{ }^{1} \mathrm{H} \delta 9.76(\mathrm{t}, J=1.69,1 \mathrm{H}), 7.30(\mathrm{t}, J$ $=7.4,2 \mathrm{H}), 7.25(\mathrm{~s}, 1 \mathrm{H}), 7.22(\mathrm{t}, J=7.2,1 \mathrm{H}), 7.18(\mathrm{~d}, J=7.3,2 \mathrm{H})$, $4.32(\mathrm{t}, J=7.2,2 \mathrm{H}), 2.73(\mathrm{t}, J=7.6,2 \mathrm{H}), 2.65(\mathrm{t}, J=7.6,2 \mathrm{H}), 2.44$ $(\mathrm{td}, J=1.7, J=7.3,2 \mathrm{H}), 2.24(\mathrm{p}, J=7.6,2 \mathrm{H}), 1.69(\mathrm{~m}, 2 \mathrm{H}), 1.58(\mathrm{p}, J$ $=6.8,2 \mathrm{H}) 1.42(\mathrm{~m}, 2 \mathrm{H}) ;{ }^{13} \mathrm{C}(176 \mathrm{MHz}) \delta 202.7,148.4,140.4,128.7$, 128.5, 126.4, 120.6, 62.9, 49.5, 43.9, 32.7, 31.8, 25.5, 21.9, 14.3; IR: 2928, 2856, 1720, 1453, 1212, 1047, $1029 \mathrm{~cm}^{-1}$; HRMS (ESI ${ }^{+}$, TOF) calcd for $\mathrm{C}_{17} \mathrm{H}_{23} \mathrm{~N}_{3} \mathrm{NaO}[\mathrm{M}+\mathrm{Na}]^{+}$: 308.1739; found: 308.1734.

4-(6-(tert-Butylperoxy)hexyl)-1-(3-phenylpropyl)-1H-1,2,3-triazole (22) via $\mathrm{CuSO}_{4}$. To a solution of 8-(tert-butylperoxy)-1octyne 2 (301.6 mg, $1.52 \mathrm{mmol})$ and 3-azidopropylbenzene 16 (260.5 mg, $1.62 \mathrm{mmol}$, 1.1 equiv.) in $\mathrm{CH}_{2} \mathrm{Cl}_{2}(4 \mathrm{~mL})$ was added $2 \mathrm{~mL}$ of an aqueous solution containing $\mathrm{CuSO}_{4}(50.7 \mathrm{mg}$, $0.32 \mathrm{mmol}, 0.2$ equiv.) and sodium ascorbate $(65.4 \mathrm{mg}$, $0.33 \mathrm{mmol}, 0.2$ equiv.). ${ }^{12,29}$ After stirring at $\mathrm{rt}$ for $3 \mathrm{~h}$, the reaction was diluted with water $(10 \mathrm{~mL})$ and extracted with $\mathrm{EA}(15 \mathrm{~mL} \times$ 3). The combined organic layers were dried with $\mathrm{Na}_{2} \mathrm{SO}_{4}$, concentrated under reduced pressure and the residue purified by column chromatography (10\% EA/Hex) to yield $223.9 \mathrm{mg}$ (41\%) of 4 -(6-(tert-butylperoxy)hexyl)-1-(3-phenylpropyl)- $1 H^{-}$ 1,2,3-triazole (22) accompanied by $139.0 \mathrm{mg}$ (37\%) of aldehyde 24.

4-(6-(tert-Butylperoxy)hexyl)-1-(3-phenylpropyl)-1H-1,2,3-triazole (22) in presence of silane. To a solution of 8 -(tertbutylperoxy)-1-octyne $2(263.8 \mathrm{mg}, 1.33 \mathrm{mmol})$ and 3-azidopropylbenzene 16 (261.0 mg, $1.34 \mathrm{mmol}, 1.0$ equiv.) in THF $(5 \mathrm{~mL})$ was added $\mathrm{CuI}\left(53.1 \mathrm{mg}, 0.28 \mathrm{mmol}, 0.2\right.$ equiv.), ${ }^{12}$ followed by triethylamine ( $0.60 \mathrm{~mL}, 4.3 \mathrm{mmol}, 3$ equiv.) and triethylsilane (0.45 mL, $2.50 \mathrm{mmol}, 1.9$ equiv.). The reaction was stirred at room temperature for 24 hours. The reaction was diluted with water $(10 \mathrm{~mL})$ and extracted with $\mathrm{EA}(15 \mathrm{~mL} \times 3)$. The combined organic layers were dried with $\mathrm{Na}_{2} \mathrm{SO}_{4}$, concentrated under reduced pressure and the residue purified by column chromatography $(10 \% \mathrm{EA} / \mathrm{Hex})$ to yield $239.0 \mathrm{mg}(50 \%)$ of 4 -(6-(tertbutylperoxy)hexyl)-1-(3-phenylpropyl)-1H-1,2,3-triazole as a yellow oil (spectra described previously).

4-(6-(tert-Butylperoxy)hexyl)-5-iodo-1-(3-phenylpropyl)-1H1,2,3-triazole (22i) from iodoalkyne 3. To a solution of 1-iodo-8tert-butylperoxy octyne $4(297.2 \mathrm{mg}, 0.917 \mathrm{mmol})$ and 3-azidopropylbenzene 16 (159.0 mg, $0.99 \mathrm{mmol}, 1.1$ equiv.) in THF (6 $\mathrm{mL}$ ) was added $\mathrm{CuI}(28.3 \mathrm{mg}, 0.15 \mathrm{mmol}, 0.2$ equiv.), followed by triethylamine $\left(0.30 \mathrm{~mL}, 2.15 \mathrm{mmol}, 2\right.$ equiv.). ${ }^{27 c}$ The reaction was stirred at room temperature for 24 hours. The reaction was diluted with water $(10 \mathrm{~mL})$ and extracted with $\mathrm{EA}(15 \mathrm{~mL} \times 3)$. The combined organic layers were dried with $\mathrm{Na}_{2} \mathrm{SO}_{4}$, concentrated under reduced pressure and the residue purified by column chromatography ( $10 \% \mathrm{EA} / \mathrm{Hex})$ to yield $338.4 \mathrm{mg}(76 \%)$ of iodotriazole 22i as a yellow oil (described previously).

\section{4-(6-(tert-Butylperoxy)hexyl)-1-(4-phenylbutyl)-1H-1,2,3-tri-}

azole (23), 4-(6-(tert-butylperoxy)hexyl)-5-iodo-1-(4-phenylbutyl)-1 $\mathrm{H}-1,2,3$-triazole (23i) and 6-(1-(4-phenylbutyl)-1H-1,2,3triazol-4-yl)hexanal (25). To a solution of 8-(tert-butylperoxy)-1octyne 2 (305.4 mg, $1.54 \mathrm{mmol})$ and 4-azidobutylbenzene 17 ( $277.0 \mathrm{mg}, 1.58 \mathrm{mmol}, 1.0$ equiv.) in THF ( $6 \mathrm{~mL}$ ) was added $\mathrm{CuI}$ ( $64.2 \mathrm{mg}, 0.34 \mathrm{mmol}, 0.2$ equiv.), followed by triethylamine ( 0.65 $\mathrm{mL}, 4.66 \mathrm{mmol}, 3$ equiv.). The reaction was stirred at room temperature for 24 hours. The reaction was diluted with water $(10 \mathrm{~mL})$ and extracted with EA $(15 \mathrm{~mL} \times 3)$. The combined organic layers were dried with $\mathrm{Na}_{2} \mathrm{SO}_{4}$, concentrated under reduced pressure and the residue purified by column chromatography (10\% EA/Hex) to yield $315.7 \mathrm{mg}$ (55\%) of $29.8 \mathrm{mg}(4 \%)$ of iodotriazole $23 \mathbf{i}, 315.7 \mathrm{mg}$ ( $55 \%$ ) of triazole 23 and $134.6 \mathrm{mg}$ (45\%) of aldehyde 25.

23: $R_{\mathrm{f}}: 0.28(40 \% \mathrm{EA} / \mathrm{Hex}):{ }^{1} \mathrm{H} \delta 7.30(\mathrm{t}, J=7.3,2 \mathrm{H}), 7.22(\mathrm{~s}$, $1 \mathrm{H}), 7.21(\mathrm{t}, J=7.5,1 \mathrm{H}), 7.16(\mathrm{~d}, J=7.4,2 \mathrm{H}), 4.33(\mathrm{t}, J=7.2,2 \mathrm{H})$, $3.94(\mathrm{t}, J=6.6,2 \mathrm{H}), 2.72(\mathrm{t}, J=7.7,2 \mathrm{H}), 2.67(\mathrm{t}, J=7.5,2 \mathrm{H}), 1.94$ (p, $J=7.6,2 \mathrm{H}), 1.58-1.72(\mathrm{~m}, 6 \mathrm{H}), 1.40-1.41(\mathrm{~m}, 4 \mathrm{H}), 1.26(\mathrm{~s}$, $9 \mathrm{H}) ;{ }^{13} \mathrm{C} \delta 148.4,141.6,128.5,128.5,126.1,120.5,80.2,75.1$, 50.1, 35.3, 29.9, 29.5, 29.2, 28.3, 27.9, 26.5, 26.1, 25.7; IR: 2977, 2920, 2860, 1454, 1362; HRMS (ESI ${ }^{+}$, TOF) calcd for $\mathrm{C}_{22} \mathrm{H}_{35} \mathrm{~N}_{3} \mathrm{NaO}_{2}[\mathrm{M}+\mathrm{Na}]^{+}: 396.2627$; found: 396.2612.

23i: ${ }^{27} R_{\mathrm{f}}: 0.32(40 \% \mathrm{EA} / \mathrm{Hex})^{1} \mathrm{H} \delta 7.30(\mathrm{t}, J=6.8,2 \mathrm{H}), 7.22(\mathrm{t}, J$ $=7.2,1 \mathrm{H}), 7.18(\mathrm{~d}, J=7.0,2 \mathrm{H}), 4.37(\mathrm{t}, J=7.3,2 \mathrm{H}), 3.95(\mathrm{t}, J=$ 6.3, $2 \mathrm{H}), 2.64-2.70(\mathrm{~m}, 4 \mathrm{H}), 1.96(\mathrm{p}, J=7.0,2 \mathrm{H}), 1.68-1.73(\mathrm{~m}$, $4 \mathrm{H}), 1.62(\mathrm{p}, J=6.5,2 \mathrm{H}), 1.38-1.46(\mathrm{~m}, 4 \mathrm{H}), 1.26(\mathrm{~s}, 9 \mathrm{H}) ;{ }^{13} \mathrm{C}$ $\delta$ 151.9, 141.6, 128.5, 128.5, 126.1, 80.2, 77.9, 75.1, 50.6, 35.2, 29.8, 29.5, 29.1, 29.0, 28.1, 27.9, 26.5, 26.1; IR: 2088, 2920, 2858, 
1454, 1361; HRMS (ESI ${ }^{+}$, TOF) calcd for $\mathrm{C}_{22} \mathrm{H}_{34} \mathrm{IN}_{3} \mathrm{NaO}_{2}[\mathrm{M}+$ $\mathrm{Na}]^{+}:$522.1593; found: 522.1581 .

25: $R_{\mathrm{f}}: 0.27(40 \% \mathrm{EA} / \mathrm{Hex}) ;{ }^{1} \mathrm{H} \delta 9.77(\mathrm{t}, J=1.7,1 \mathrm{H}), 7.30(\mathrm{t}, J=$ $7.4,2 \mathrm{H}), 7.22(\mathrm{~s}, 1 \mathrm{H}), 7.21(\mathrm{t}, J=7.4,1 \mathrm{H}), 7.16(\mathrm{~d}, J=7.4,2 \mathrm{H})$, $4.33(\mathrm{t}, J=7.2,2 \mathrm{H}), 2.73(\mathrm{t}, J=7.6,2 \mathrm{H}), 2.67(\mathrm{t}, J=7.6,2 \mathrm{H}), 1.94$ (p, $J=7.7,2 \mathrm{H}), 1.63-1.73(\mathrm{~m}, 4 \mathrm{H}), 1.59(\mathrm{p}, J=6.6,2 \mathrm{H}), 1.37-1.45$ $(\mathrm{m}, 4 \mathrm{H}) ;{ }^{13} \mathrm{C}(176 \mathrm{MHz}) \delta 202.8,148.4,141.6,128.5,128.5,126.1$, 120.5, 62.9, 50.1, 43.9, 35.3, 32.7, 29.9, 28.3, 25.5, 21.9; IR: 2920, $2858,1721,1454$; HRMS (ESI ${ }^{+}$, TOF) calcd for $\mathrm{C}_{18} \mathrm{H}_{25} \mathrm{~N}_{3} \mathrm{NaO}[\mathrm{M}+$ $\mathrm{Na}^{+}: 322.1895^{\prime}$; found: 322.1882 .

4-(6-(tert-Butylperoxy)hexyl)-1-(4-phenylbutyl)-1H-1,2,3-triazole (23) and 6-(1-(4-phenylbutyl)-1H-1,2,3-triazol-4-yl)hexanal (25). To a solution of 8-(tert-butylperoxy)-1-octyne 2 (305.1 $\mathrm{mg}, 1.54 \mathrm{mmol}$ ) and 4-azidobutylbenzene 17 (272.3 $\mathrm{mg}$, $1.55 \mathrm{mmol}, 1.0$ equiv.) in $\mathrm{CH}_{2} \mathrm{Cl}_{2}$ (4 mL) was added a solution of $\mathrm{CuSO}_{4}(59.2 \mathrm{mg}, 0.37 \mathrm{mmol}, 0.2$ equiv.) and sodium ascorbate (75.5 mg, $0.38 \mathrm{mmol}, 0.2$ equiv.) in water $(2 \mathrm{~mL}) .{ }^{12}$ The reaction was stirred at room temperature for 24 hours. The reaction was diluted with water $(10 \mathrm{~mL})$ and extracted with $\mathrm{EA}(15 \mathrm{~mL} \times 3)$. The combined organic layers were dried with $\mathrm{Na}_{2} \mathrm{SO}_{4}$, concentrated under reduced pressure and the residue purified by column chromatography (10\% EA/Hex) to yield $225.7 \mathrm{mg}$ (39\%) of peroxy triazole 23 as a yellow oil accompanied by $231.4 \mathrm{mg}(50 \%)$ of aldehyde 25 .

\section{Click reaction of peroxyacetals}

To a solution of 4-((2-methylperoxypropan-2-yl)oxy)-1-butyne 8 (166 mg, $1.05 \mathrm{mmol}$ ) and 4-azidobutylbenzene 17 (193 mg, 1.10 $\mathrm{mmol})$ in THF (6 mL) was added CuI $(38.1 \mathrm{mg}, 0.20 \mathrm{mmol}, 0.2$ equiv.), followed by triethylamine $(0.28 \mathrm{~mL}, 2.01 \mathrm{mmol}, 3$ equiv.). The reaction was stirred at room temperature for 1.5 hours. The reaction was diluted with water $(10 \mathrm{~mL})$ and extracted with $\mathrm{EA}(15 \mathrm{~mL} \times 3)$. The combined organic layers were dried with $\mathrm{Na}_{2} \mathrm{SO}_{4}$, concentrated under reduced pressure and the residue purified by column chromatography $(10 \% \mathrm{EA} / \mathrm{Hex})$ to yield a light yellow oil as a nearly inseparable mixture of 4 -(2-((2(methylperoxy)propan-2-yl)oxy)ethyl)-1-(4-phenylbutyl)-1H-1,2,3-triazole and 4-(2-acetoxyethyl)-1-(4-phenylbutyl)-1H-1,2,3-triazole. The peroxyacetal, typically formed in less than $10 \%$ yield, was contaminated with variable amounts of the ester.

4-(2-((2-(Methylperoxy)propan-2-yl)oxy)ethyl)-1-(4-phenylbutyl)-1H-1,2,3-triazole. $R_{\mathrm{f}}=0.34(30 \% \mathrm{EA} / \mathrm{Hex}) ;{ }^{1} \mathrm{H} \delta 7.32(\mathrm{t}, J=$ $7.1,2 \mathrm{H}), 7.27(\mathrm{~s}, 1 \mathrm{H}), 7.24(\mathrm{t}, J=7.7,1 \mathrm{H}), 7.23(\mathrm{~d}, J=7.5,2 \mathrm{H})$, $4.38(\mathrm{t}, J=7.2,2 \mathrm{H}), 3.86(\mathrm{t}, J=7.6,2 \mathrm{H}), 3.84(\mathrm{~s}, 3 \mathrm{H}), 2.97(\mathrm{t}, J=$ $7.5,2 \mathrm{H}), 2.71(\mathrm{t}, J=7.3,2 \mathrm{H}), 2.26(\mathrm{p}, J=7.4,2 \mathrm{H}), 1.28(\mathrm{~s}, 6 \mathrm{H})$; ${ }^{13} \mathrm{C} \delta$ 149.3, 140.4, 128.7, 128.6, 126.4, 104.9, 63.3, 60.7, 50.2, 32.6, 31.4, 29.8, 27.4, 23.2.

4-(4-((2-(Methylperoxy)propan-2-yl)oxy)butyl)1-(3-phenylpropyl)-1H-1,2,3-triazole (26). To a solution of 6-((2methylperoxypropan-2-yl)oxy)-1-hexyne 10 (102 mg, $0.55 \mathrm{mmol})$ and 4-azidobutylbenzene 17 (98.1 $\mathrm{mg}, 0.56 \mathrm{mmol}$ ) in THF ( $5 \mathrm{~mL}$ ) was added CuI (20.9 mg, $0.11 \mathrm{mmol}, 0.2$ equiv.), followed by triethylamine ( $0.23 \mathrm{~mL}, 1.7 \mathrm{mmol}, 3$ equiv.). The reaction was stirred at room temperature for 3 hours. The reaction was diluted with water $(10 \mathrm{~mL})$ and extracted with EA $(15 \mathrm{~mL} \times 3)$. The combined organic layers were dried with $\mathrm{Na}_{2} \mathrm{SO}_{4}$, concentrated under reduced pressure and the residue purified by column chromatography $(10 \% \mathrm{EA} / \mathrm{Hex})$ to yield $88.5 \mathrm{mg}$ (45\%) of the peroxyacetal/triazole 26 as a yellow oil: $R_{\mathrm{f}}=0.28$ $(30 \% \mathrm{EA} / \mathrm{Hex}) ;{ }^{1} \mathrm{H} \delta 7.32(\mathrm{t}, J=7.3,2 \mathrm{H}), 7.27(\mathrm{~s}, 1 \mathrm{H}), 7.23(\mathrm{t}, J=$ $7.4,1 \mathrm{H}), 7.19(\mathrm{~d}, J=7.2,2 \mathrm{H}), 4.33(\mathrm{t}, J=7.1,2 \mathrm{H}), 3.85(\mathrm{~s}, 3 \mathrm{H})$, $3.56(\mathrm{t}, J=6.5,2 \mathrm{H}), 2.77(\mathrm{t}, J=7.5,2 \mathrm{H}), 2.67(\mathrm{t}, J=7.5,2 \mathrm{H}), 2.25$ $(\mathrm{p}, J=7.3,2 \mathrm{H}), 1.82-1.56(\mathrm{~m}, 4 \mathrm{H}), 1.40(\mathrm{~s}, 6 \mathrm{H}) ;{ }^{13} \mathrm{C} \delta 148.0$, 140.4, 128.7, 128.6, 126.4, 120.7, 104.7, 63.3, 61.3, 49.5, 32.7, 31.8, 29.6, 26.2, 25.6, 23.2; IR: 3025, 2926, 2858, 2202, 1736, 1454, 1365, 1207, 1066, 748, 701; HRMS (ESI ${ }^{+}, \mathrm{TOF}$ ) calcd for $\mathrm{C}_{19} \mathrm{H}_{29} \mathrm{~N}_{3} \mathrm{NaO}_{30} \cdot[\mathrm{M}+\mathrm{Na}]^{+}: 370.2107$; found: 370.2103 .

5-Iodo-4-(4-((2-(methylperoxy)propan-2-yl)oxy)butyl)-1-(3phenylpropyl)-1H-1,2,3-triazole (27i). To a solution of 1-iodo-6((2-methylperoxypropan-2-yl)oxy)-1-hexyne 11 (172 mg, 0.55 $\mathrm{mmol}$ ) and 3-azidopropylbenzene 16 (96.7 $\mathrm{mg}, 0.60 \mathrm{mmol})$ in THF ( $5 \mathrm{~mL}$ ) was added CuI (10.5 mg, $0.055 \mathrm{mmol}, 0.1$ equiv.), followed by triethylamine $(0.15 \mathrm{~mL}, 1.08 \mathrm{mmol}, 2$ equiv.). The reaction was stirred at room temperature for 24 hours. The reaction was diluted with water $(10 \mathrm{~mL})$ and extracted with EA $(15 \mathrm{~mL} \times 3)$. The combined organic layers were dried with $\mathrm{Na}_{2} \mathrm{SO}_{4}$, concentrated under reduced pressure and the residue purified by column chromatography $(10 \% \mathrm{EA} / \mathrm{Hex})$ to yield $84.5 \mathrm{mg}$ (33\%) of peroxyacetal/iodotriazole $27 \mathbf{i}$ as a light yellow oil: $R_{\mathrm{f}}=0.31(30 \% \mathrm{EA} / \mathrm{Hex}) ;{ }^{1} \mathrm{H} \delta 7.31(\mathrm{t}, J=7.0,2 \mathrm{H}), 7.23(\mathrm{t}, J=$ $7.0,1 \mathrm{H}), 7.21(\mathrm{~d}, J=7.7), 4.36(\mathrm{t}, J=7.2,2 \mathrm{H}), 3.85(\mathrm{~s}, 3 \mathrm{H}), 3.56(\mathrm{t}$, $J=6.6,2 \mathrm{H}), 2.70(\mathrm{t}, J=7.6,2 \mathrm{H}), 2.25(\mathrm{p}, J=7.4,2 \mathrm{H}), 1.84-1.62$ $(\mathrm{m}, 4 \mathrm{H}), 1.40(\mathrm{~s}, 6 \mathrm{H}) ;{ }^{13} \mathrm{C} \delta 151.7,140.4,128.6,128.5,126.4$, 104.7, 78.1, 63.3, 61.3 , 50.1, 32.6, 31.3, 29.5, 26.0, 25.7, 23.2; IR: 3356, 3026, 2934, 2860, 1733, 1453, 1210, 1028, 745, 699; HRMS $\left(\mathrm{ESI}^{+}\right.$, TOF) calcd for $\mathrm{C}_{15} \mathrm{H}_{20} \mathrm{IN}_{3} \mathrm{NaO}\left[\left(\mathrm{M}-\mathrm{C}_{4} \mathrm{H}_{8} \mathrm{O}_{2}\right)+\mathrm{Na}\right]^{+}$; elim. with loss of peroxyacetal] $]^{+}: 408.0549$; found: 408.0549 .

\section{Click reaction with azidoalkyl peroxides}

4-Butyl-1-(4-(tert-butylperoxy)butyl)-1H-1,2,3-triazole (28). To a solution of 1-azido-(4-(tert-butylperoxy)butane 12 (142 mg, 0.76 $\mathrm{mmol}$ ) and 1-hexyne 14 (65.7 mg, $0.80 \mathrm{mmol})$ in THF (3.5 mL) was added $\mathrm{CuI}$ (30.5 mg, $0.16 \mathrm{mmol}, 0.2$ equiv.), followed by triethylamine (0.32 mL, $2.30 \mathrm{mmol}, 3$ equiv.). After stirring for 3.5 hours, the reaction was diluted with water $(10 \mathrm{~mL})$. The combined EA extracts $(15 \mathrm{~mL} \times 3)$ were dried with $\mathrm{Na}_{2} \mathrm{SO}_{4}$, and concentrated under reduced pressure. The residue was purified by column chromatography $(10 \% \mathrm{EA} / \mathrm{Hex})$ to yield $69.5 \mathrm{mg}(34 \%)$ of peroxy triazole 28 as a light yellow oil: $R_{\mathrm{f}}=0.25(40 \% \mathrm{EA} / \mathrm{Hex}) ;{ }^{1} \mathrm{H} \delta 7.26(\mathrm{~s}$, $1 \mathrm{H}), 4.34(\mathrm{t}, J=7.2,2 \mathrm{H}), 3.95(\mathrm{t}, J=6.2,2 \mathrm{H}), 2.70(\mathrm{t}, J=7.7,2 \mathrm{H})$, $1.98(\mathrm{p}, J=7.5,2 \mathrm{H}), 1.64(\mathrm{p}, J=7.4,2 \mathrm{H}), 1.62(\mathrm{p}, J=7.4,2 \mathrm{H}), 1.37$ (tt, $J=14.9, J=7.4,2 \mathrm{H}), 1.22(\mathrm{~s}, 9 \mathrm{H}), 0.92(\mathrm{t}, J=7.3,3 \mathrm{H}) ;{ }^{13} \mathrm{C}$ $\delta$ 148.5, 120.6, 80.4 , 74.2, 50.0, 31.7, 27.5, 26.4, 25.5, 25.1, 22.4, 14.0; IR: 3133, 2931, 2097, 1458, 1362, 1196, 1046, 880; HRMS (ESI ${ }^{+}$, TOF) calcd for $\mathrm{C}_{14} \mathrm{H}_{27} \mathrm{~N}_{3} \mathrm{NaO}_{2}[\mathrm{M}+\mathrm{Na}]^{+}:$292.2001; found: 292.2003 .

4-(4-(tert-Butylperoxy)butyl)-1-(4-phenylbutyl)-1H-1,2,3-triazole (29). By a similar procedure as for synthesis of 28 (above), reaction of a THF solution $(3.5 \mathrm{~mL})$ of 1-azido-(4-(tert-butylperoxy)butane 12 (140 $\mathrm{mg}, 0.75 \mathrm{mmol})$ and 5-hexynyl benzene 15 (125 mg, $0.79 \mathrm{mmol}$ ), CuI (30.5 mg, $0.16 \mathrm{mmol}, 0.2$ equiv.), and triethylamine $(0.32 \mathrm{~mL}, 2.30 \mathrm{mmol}, 3$ equiv. $)$ furnished $38.5 \mathrm{mg}(15 \%)$ of peroxy triazole 29 as a light yellow oil: $R_{\mathrm{f}}=$ 
$0.23(40 \% \mathrm{EA} / \mathrm{Hex}) ;{ }^{1} \mathrm{H} \delta 7.31-7.17(\mathrm{~m}, 6 \mathrm{H}), 4.39(\mathrm{t}, J=7.3,2 \mathrm{H})$, $3.99(\mathrm{t}, J=6.2,2 \mathrm{H}), 2.77-2.64(\mathrm{~m}, 4 \mathrm{H}), 2.02(\mathrm{~m}, 2 \mathrm{H}), 1.83-1.61$ $(\mathrm{m}, 6 \mathrm{H}), 1.26(\mathrm{~s}, 9 \mathrm{H}) ;{ }^{13} \mathrm{C} \delta 152.1,142.5,128.6,128.5,128.4$, 125.8, 80.3, 74.0, 50.6, 35.7, 31.0, 28.7, 27.0, 26.5, 26.1, 25.1; IR: 3026, 2925, 2155, 2032, 1454, 1362, 1196, 699; HRMS (ESI ${ }^{+}$, TOF) calcd for $\mathrm{C}_{20} \mathrm{H}_{31} \mathrm{~N}_{3} \mathrm{NaO}_{2}[\mathrm{M}+\mathrm{Na}]^{+}$: 368.2314; found: 368.2313.

4-Butyl-1-(4-(tert-butylperoxy)butyl)-1H-1,2,3-triazole $\mathrm{CuSO}_{4}$ catalyst). To a solution of azidoperoxide $12(0.80 \mathrm{mmol})$ and 1-hexyne $14(0.9 \mathrm{mmol})$ in $\mathrm{CH}_{2} \mathrm{Cl}_{2}(3.5 \mathrm{~mL})$ was added a solution of $\mathrm{CuSO}_{4}(0.16 \mathrm{mmol}, 0.2$ equiv. $)$ and sodium ascorbate $(0.16 \mathrm{mmol}, 0.2$ equiv.) in water $(1.5 \mathrm{~mL})$. After stirring for $24 \mathrm{~h}$, the reaction was diluted with water. The combined ethyl acetate extracts $(3 \times 15 \mathrm{~mL})$ were dried with $\mathrm{Na}_{2} \mathrm{SO}_{4}$, concentrated under reduced pressure and purified by column chromatography (10\% EA/Hex) to yield $61.7 \mathrm{mg}$ (29\%) of peroxy triazole 28 as a light yellow oil: $R_{\mathrm{f}}=0.25(40 \% \mathrm{EA} / \mathrm{Hex})$.

4-(4-(tert-Butylperoxy)butyl)-1-(4-phenylbutyl)-1H-1,2,3-triazole $\left(29, \mathrm{CuSO}_{4}\right.$ catalyst). By a similar procedure as described above for synthesis of $\mathbf{2 8}$, reaction of azidoperoxybutane $\mathbf{1 2}$ and hexynyl benzene (15) with $\mathrm{CuSO}_{4}$ and sodium ascorbate in $\mathrm{CH}_{2} \mathrm{Cl}_{2}$ water furnished $7.1 \mathrm{mg}$ (5\%) of peroxy triazole 29.

\section{Unsuccessful click reaction involving silylperoxy/azide 13}

Reaction of peroxide $\mathbf{1 3}$ with alkynes $\mathbf{1 4}$ or $\mathbf{1 5}$ in the presence of $20 \% \mathrm{CuI} / \mathrm{Et}_{3} \mathrm{~N}$ under conditions similar to those described earlier furnished a mixture of peroxide decomposition products. The same reaction, when conducted in the presence of $20 \% \mathrm{CuSO}_{4} /$ sodium ascorbate resulted in no detectable reaction (TLC) and extensive recovery of $\mathbf{1 3 .}$

\section{Preparation of functionalized nanoparticles}

Synthesis of pentanethiolate functionalized gold nanoparticles was adapted from a reported procedure. ${ }^{38 a}$ An aqueous solution of hydrogen tetrachloroaurate $(10 \mathrm{~mL}, 30 \mathrm{mmol}, 30 \mathrm{mM})$ was vigorously stirred with a toluene solution of tetraoctylammonium bromide $(27 \mathrm{~mL}, 50 \mathrm{mmol}, 50 \mathrm{mM})$ until the tetrachloroaurate was transferred into the organic toluene layer. Pentanethiol (42 mg) was then added to the organic phase, followed by the addition of freshly prepared aqueous solution of sodium borohydride $(8.33 \mathrm{~mL}, 3.3 \mathrm{mmol}, 0.4 \mathrm{M})$. After the reaction had stirred for 3 hours at room temperature, the organic layer was separated and concentrated under reduced pressure to a volume of $\sim 1 \mathrm{~mL}$. The concentrated layer was mixed with $125 \mathrm{~mL}$ of methanol and held at $-18 \mathrm{C}$ for 4 hours. The resulting solution was centrifuged. The nanoparticle-containing pellet was resuspended (methanol, $25 \mathrm{~mL}$ ) and again centrifuged $(3 \times)$ to yield $(73.1 \mathrm{mg})$ a brown precipitate: ${ }^{1} \mathrm{H} \delta 1.32(4 \mathrm{H}), 0.92(3 \mathrm{H}) ;{ }^{39}$ IR: 2956, 2921; elemental analysis: Au, 50.1; C, 43.9; S, 6.0\%; XPS (binding energies): $\mathrm{Au} 4 \mathrm{f}_{7 / 2}(82.6 \mathrm{eV}), \mathrm{Au} 4 \mathrm{f}_{5 / 2}(86.4 \mathrm{eV}), \mathrm{C} 1 \mathrm{~s}(284.3 \mathrm{eV}), \mathrm{S} 2 \mathrm{p}$ $(161.2 \mathrm{eV})$. Solutions of the nanoparticles displayed a broad absorption in the following paragraph, a dodecanethiol-passivated set of nanoparticles prepared as a standard, and which did display the small $520 \mathrm{~nm}$ bump, otherwise exhibited identical properties to the $\mathrm{C} 5$ nanoparticles. ${ }^{71}$
Dodecanethiolate functionalized gold nanoparticles. Synthesis of dodecanethiolate functionalized gold nanoparticles were prepared following a reported procedure. ${ }^{38 a}$ An aqueous solution of hydrogen tetrachloroaurate $(10 \mathrm{~mL}$, $30 \mathrm{mmol}, 30 \mathrm{mM}$ ) was vigorously stirred with a toluene solution of tetraoctylammonium bromide $(27 \mathrm{~mL}, 50 \mathrm{mmol}, 50 \mathrm{mM})$ until the tetrachloroaurate was transferred into the organic toluene layer. Dodecanethiol (57 $\mathrm{mg}$ ) was then added to the organic phase, followed by the addition of freshly prepared aqueous solution of sodium borohydride $(8.33 \mathrm{~mL}, 3.3 \mathrm{mmol}$, $0.4 \mathrm{M}$ ). The reaction was stirred for 3 hours at room temperature. After 3 hours of stirring at room temperature, the organic layer was separate, and concentrated under reduced pressure to $1 \mathrm{~mL}$, and mixed with $125 \mathrm{~mL}$ of methanol to remove excess thiol and kept at $-18 \mathrm{C}$ for 4 hours. The solution was centrifuged and washed with methanol $(25 \mathrm{~mL} \times 3)$ to yield $(73.1 \mathrm{mg})$ a black precipitate: ${ }^{1} \mathrm{H} \delta 1.27(10 \mathrm{H}), 0.91$ (3H); IR: 2956, 2920; UV-vis: $520.65 \mathrm{~nm}$ (diagnostic signal; see ESI $\dagger$ ); elemental analysis: Au, 78.4; C, 17.7; S, 3.9\%; XPS (binding energies): $\mathrm{Au}$ $4 \mathrm{f}_{7 / 2}(82.9 \mathrm{eV}), \mathrm{Au} 4 \mathrm{f}_{5 / 2}(86.6 \mathrm{eV}), \mathrm{C} 1 \mathrm{~s}(283.8 \mathrm{eV}), \mathrm{S} 2 \mathrm{p}(161.0 \mathrm{eV})$.

Azide functionalized gold nanoparticles $\left(\mathbf{N}_{3} \mathbf{A u}\right)$ were prepared via a modification of reported procedures. ${ }^{36}$ To a solution of $\mathbf{C}_{5} \mathbf{S H}-\mathbf{A u} \mathrm{P}(47.9 \mathrm{mg})$ in $\mathrm{CH}_{2} \mathrm{Cl}_{2}(5 \mathrm{~mL})$ was added 6azidohexane-1-thiol (142.5 mg). After stirring for 3 days at room temperature under nitrogen, the reaction solution was concentrated under reduced pressure and pelleted/ resuspended $(6 \times 10 \mathrm{~mL}$, methanol $)$ to yield $(62.3 \mathrm{mg})$ a brown precipitate: ${ }^{1} \mathrm{H} \delta 3.31(2 \mathrm{H}), 1.45(2 \mathrm{H}), 1.28(4 \mathrm{H}), 0.87$ (3H); IR: 2922, 2851, 2094; elemental analysis: Au, 54.0; C, 34.2; $\mathrm{S}, 8.5$; N, 3.3\%; XPS (binding energies): $\mathrm{Au} 4 \mathrm{f}_{7 / 2}(83.1 \mathrm{eV}), \mathrm{Au} 4 \mathrm{f}_{5 /}$ ${ }_{2}(86.9 \mathrm{eV}), \mathrm{C}$ 1s $(283.9 \mathrm{eV}), \mathrm{S} 2 \mathrm{p}(162.0 \mathrm{eV}), \mathrm{N} 1 \mathrm{~s}(398.3 \mathrm{eV})$.

Peroxide functionalized gold nanoparticles (PeroxideAu) were prepared via a modification of reported procedures. ${ }^{37}$ To a solution of 6-(tert-butylperoxy)-1-hexyne (182.9 mg, 1.07 $\mathrm{mmol}$ ) and azidoalkylthiolate Au-NP $(23.4 \mathrm{mg})$ in THF $(5 \mathrm{~mL})$ was added $\mathrm{CuI}$ (41.7 mg, $0.22 \mathrm{mmol}, 0.2$ equiv. per alkyne), followed by triethylamine $(0.50 \mathrm{~mL}, 3.6 \mathrm{mmol}, 3$ equiv. per alkyne). The reaction was stirred at room temperature for 8 hours. The reaction was diluted with saturated aqueous solution of $\mathrm{NH}_{4} \mathrm{Cl}(10 \mathrm{~mL})$ and the organic layer was washed with water $(10 \mathrm{~mL} \times 3)$. The organic layer was dried with $\mathrm{Na}_{2} \mathrm{SO}_{4}$, concentrated under reduced pressure and washed with methanol $(10 \mathrm{~mL} \times 6)$ to remove excess alkyne to yield $(29.8 \mathrm{mg})$ a light brown precipitate: ${ }^{1} \mathrm{H} \delta 3.99(2 \mathrm{H}), 2.47(2 \mathrm{H}), 1.60-1.75$ $(8 \mathrm{H}), 1.26-1.30(11 \mathrm{H}), 0.88$ (1.5 H) IR: 2975, 2926, 2865, 1723, 1559, 1463, 1362, 1022, 803; elemental analysis: Au, 26.4; C, 49.9; S, 4.7; N, 5.1; O, 13.9\%; XPS (binding energies): Au $4 \mathrm{f}_{7 / 2}$ (84.0 eV), Au 4f 5 5/2 $(87.8 \mathrm{eV}), \mathrm{C} 1 \mathrm{~s}(284.3 \mathrm{eV}), \mathrm{S} 2 \mathrm{p}$ (162.9 eV), N 1s (399.6 eV), O 1s (531.5 eV).

Peroxyacetal functionalized gold nanoparticles (PeroxyacetalAu). To a solution of 6-((2-peroxypropan-2-yl)oxy)-1hexyne (197.9 mg, $1.06 \mathrm{mmol}$ ) and azidoalkylthiolate Au-NP (28.2 mg) in THF $(5 \mathrm{~mL})$ was added CuI (41.4 mg, $0.22 \mathrm{mmol}$, 0.2 equiv. per alkyne), followed by triethylamine $(0.50 \mathrm{~mL}$, $3.6 \mathrm{mmol}, 3$ equiv. per alkyne). The reaction was stirred at room temperature for 8 hours. The reaction was diluted with 
saturated aqueous solution of $\mathrm{NH}_{4} \mathrm{Cl}(10 \mathrm{~mL})$ and the organic layer was washed with water $(10 \mathrm{~mL} \times 3)$. The organic layer was dried with $\mathrm{Na}_{2} \mathrm{SO}_{4}$, concentrated under reduced pressure and washed with methanol $(10 \mathrm{~mL} \times 6)$ to remove excess alkyne to yield $(14.1 \mathrm{mg})$ a yellow precipitate: ${ }^{1} \mathrm{H} \delta 3.86(2 \mathrm{H}), 2.05(2 \mathrm{H})$, $1.67(2 \mathrm{H}), 1.57(6 \mathrm{H}), 1.39(5 \mathrm{H}), 1.28(4 \mathrm{H}), 1.12(4 \mathrm{H}), 0.91(5 \mathrm{H})$; IR: 3411, 2921, 2851, 1738, 1240, 1065; elemental analysis: $\mathrm{Au}$, 20.0; C, 52.6; S, 4.3; N, 4.6; O, 18.5\%; XPS (binding energies): Au $4 \mathrm{f}_{7 / 2}(83.9 \mathrm{eV})$, Au $4 \mathrm{f}_{5 / 2}(87.6 \mathrm{eV}), \mathrm{C} 1 \mathrm{~s}(284.0 \mathrm{eV}), \mathrm{S} 2 \mathrm{p}(163.2$ eV), N 1s (399.3 eV), O 1s (531.5 eV).

\section{Abbreviations}

$\begin{array}{ll}\text { Hexane }(\mathrm{s}) & \text { Hex } \\ \text { EA } & \text { Ethyl acetate } \\ \text { THF } & \text { Tetrahydrofuran } \\ \text { DMF } & N, N \text {-Dimethylformamide } \\ \text { DMSO } & \text { Dimethyl sulfoxide } \\ \text { EtOH } & \text { Ethanol } \\ \text { MeOH } & \text { Methanol } \\ \text { TEA } & \text { Triethylamine } \\ \text { Na ascorb. } & \text { Sodium ascorbate } \\ \text { TBHP } & \text { tert-Butyl hydroperoxide } \\ \text { TBTA } & \text { Tris[(1-benzyl-1H-1,2,3-triazol-4-yl)methyl]amine } \\ \text { Co(acac })_{2} & \text { Cobalt(II) acetylacetonate }\end{array}$

\section{Conflicts of interest}

There are no conflicts of interest to declare.

\section{Acknowledgements}

Funding was provided by NSF (CHE 1464914) and by Dr In Quen Lee. Materials characterization was performed in part in the Nebraska Nanoscale Facility: National Nanotechnology Coordinated Infrastructure and the Nebraska Center for Materials and Nanoscience, facilities supported by NSF (ECCS 1542182) and the Nebraska Research Initiative. We thank Prof. Martha Morton, Ms Nataliia Vorobyova, Dr Moriah Locklear, and $\mathrm{Mr}$ Boone Evans for technical assistance and/or insightful suggestions.

\section{References}

1 (a) I. A. Yaremenko, V. A. Vil, D. V. Demchuk and A. O. Terent'ev, Rearrangements of organic peroxides and related processes, Beilstein J. Org. Chem., 2016, 12, 16471748; (b) P. Dussault, Reactions of Hydroperoxides and Peroxides, in Active Oxygen In Chemistry, Chapman \& Hall, London, 1995, pp. 141-203; (c) The Chemistry of Peroxides, ed. J. F. Liebman and A. Greer, Wiley, 2014, vol. 3, p. 1120, ISBN: 978-1-118-41271-8.

2 For example, see: A. Banerjee and H. Yamamoto, Direct N-O bond formation via oxidation of amines with benzoyl peroxide, Chem. Sci., 2019, 10, 2124-2129.
3 G. O. Wilson, J. W. Henderson, M. M. Caruso, B. J. Blaiszik, P. J. McIntire, N. R. Sottos, S. R. White and J. S. Moore, Evaluation of peroxide initiators for radical polymerization-based self-healing applications, J. Polym. Sci., Part A: Polym. Chem., 2010, 48, 2698-2708.

4 P. M. O'Neill, V. E. Barton and S. A. Ward, The molecular mechanism of action of artemisinin-the debate continues, Molecules, 2010, 15, 1705-1721.

5 P. H. Dussault, A. D. George and T. K. Trullinger, Peroxides as oxidative enzyme inhibitors: mechanism-based inhibition of a cysteine protease by an amino acid ozonide, Bioorg. Med. Chem. Lett., 1999, 9, 3255-3258.

6 S. Kyasa, R. N. Meier, R. A. Pardini, T. K. Truttmann, K. T. Kuwata and P. H. Dussault, Synthesis of Ethers via Reaction of Carbanions and Monoperoxyacetals, J. Org. Chem., 2015, 80, 12100-12114.

7 (a) N. A. Porter, A perspective on free radical autoxidation: the physical organic chemistry of polyunsaturated fatty acid and sterol peroxidation, J. Org. Chem., 2013, 78, 35113524; (b) A. Bodin, M. Linnerborg, J. L. G. Nilsson and A.-T. Karlberg, Structure Elucidation, Synthesis, and Contact Allergenic Activity of a Major Hydroperoxide Formed at Autoxidation of the Ethoxylated Surfactant C12E5, Chem. Res. Toxicol., 2003, 16, 575-582.

8 (a) T. M. McIntire, O. Ryder and B. Finlayson-Pitts, Secondary ozonide formation from the ozone oxidation of unsaturated self-assembled monolayers on zinc selenide attenuated total reflectance crystals, J. Phys. Chem. C, 2009, 113, 11060-11065; (b) A. Razgon, R. G. Bergman and C. N. Sukenik, Ozonolysisbased route to the in situ formation of aldehyde-bearing selfassembled monolayer surfaces, Langmuir, 2008, 24, 25452552.

9 (a) H. X. Jin, H. H. Liu, Q. Zhang and Y. Wu, On the susceptibility of organic peroxy bonds to hydride reduction, J. Org. Chem., 2005, 70, 4240-4247; (b) I. Opsenica, D. Opsenica, K. S. Smith, W. K. Milhous and B. A. Šlaja, Chemical stability of the peroxide bond enables diversified synthesis of potent tetraoxane antimalarials, J. Med. Chem., 2008, 51, 2261-2266; (c) P. Dussault, The peroxide changes everything: new methodology for the synthesis of peroxide-containing natural products, Synlett, 1995, 997-1003; (d) H. O'Dowd, P. Ploypradith, S. Xie, T. A. Shapiro and G. H. Posner, Antimalarial artemisinin analogs. Synthesis via chemoselective C-C bond formation and preliminary biological evaluation, Tetrahedron, 1999, 55, 3625-3636; (e) P. H. Dussault and C. T. Eary, Palladium-Mediated Carbon- Carbon Bond Forming Reactions as a New Method for the Synthesis of Peroxides and Hydroperoxides, J. Am. Chem. Soc., 1998, 120, 7133-7134.

10 (a) J. Zabicky, Analytical and Safety Aspects of Organic Peroxides and Related Functional Groups, in The Chemistry of the Peroxide Group, ed. Z. Rappoport, John Wiley \& Sons, Chichester, 2006, vol. 2, pt 2, pp. 597-773; ISBN: 978-0-47086274-2; (b) D. E. Clark, Peroxides and Peroxide-forming Compounds, J. Chem. Health Saf., 2001, 8, 12-21; (c) G. D. Kozak, A. N. Tsvigunov and N. I. Akinin, Similarities 
and Differences in Explosion Hazards of Organic Peroxides and High Explosives: an Experimental Study, Cent. Eur. J. Energ. Mater., 2011, 8, 249-260; (d) P. H. Dussault, Working with Organic Peroxides in the Academic Lab, Department of Chemistry, University of Nebraska-Lincoln; Digital Commons@University of Nebraska Lincoln; DOI: 10.13014/ K2GT5KCJ; accessed July 2020.

11 (a) C. S. McKay and M. G. Finn, Click chemistry in complex mixtures: bioorthogonal bioconjugation, Chem. Biol., 2014, 21, 1075-1101; (b) W. H. Binder and R. Sachsenhofer, 'Click' chemistry in polymer and materials science, Macromol. Rapid Commun., 2007, 28, 15-54; (c) J. E. Moses and A. D. Moorhouse, The growing applications of click chemistry, Chem. Soc. Rev., 2007, 36, 1249-1262; (d) H. C. Kolb and K. B. Sharpless, The growing impact of click chemistry on drug discovery, Drug Discovery Today, 2003, 8, 1128-1137; (e) R. Chelmowski, D. Kafer, S. D. Köster, T. Klasen, T. Winkler, A. Terfort, N. MetzlerNolte and C. Wöll, Postformation modification of SAMs: using click chemistry to functionalize organic surfaces, Langmuir, 2009, 25, 11480-11485.

12 (a) M. Meldal and C. W. Tornøe, Cu-catalyzed azide- alkyne cycloaddition, Chem. Rev., 2008, 108, 2952-3015; (b) J. E. Hein and V. V. Fokin, Copper-catalyzed azide-alkyne cycloaddition and beyond: new reactivity of copper acteylides, Chem. Soc. Rev., 2011, 39, 1302-1315; (c) L. Zhu, C. J. Brassard, X. Zhang, P. M. Guha and R. J. Clark, On the Mechanism of Copper(I)-Catalyzed Azide-Alkyne Cycloaddition, Chem. Rec., 2016, 16, 1501-1517.

13 (a) S. Jana, S. Iram, J. Thomas, S. Liekens and W. Dehaen, Synthesis and anticancer activity of novel aza-artemisinin derivatives, Bioorg. Med. Chem., 2017, 25, 3671-3676; (b) H. M. Ismail, V. E. Barton, M. Panchana, S. Charoensutthivarakul, G. A. Biagini, S. A. Ward and P. M. O'Neill, A Click Chemistry-Based Proteomic Approach Reveals that 1,2,4-Trioxolane and Artemisinin Antimalarials Share a Common Protein Alkylation Profile, Angew. Chem., Int. Ed., 2016, 55, 6401-6405; (c) W. Li, Y. Zhou, G. Tang and Y. Xiao, Characterization of the Artemisinin Binding Site for Translationally Controlled Tumor Protein (TCTP) by Bioorthogonal Click Chemistry, Bioconjugate Chem., 2016, 27, 2828-2833; (d) L. H. Binh, N. T. T. Van, V. T. Kien, N. T. T. My, L. Van Chinh, N. T. Nga, H. X. Tien, D. T. Thao and T. K. Vu, Synthesis and in vitro cytotoxic evaluation of new triazole derivatives based on artemisinin via click chemistry, Med. Chem. Res., 2016, 25, 738-750.

14 (a) Y. Chen, J. Q. Ren, X. G. Zhang, D. Y. Wu, A. G. Shen and J. M. Hu, Alkyne-Modulated Surface-Enhanced Raman Scattering-Palette for Optical Interference-Free and Multiplex Cellular Imaging, Anal. Chem., 2016, 88, 61156119; (b) R. Kozlowski, A. Ragupathi and R. B. Dyer, Characterizing the Surface Coverage of Protein-Gold Nanoparticle Bioconjugates, Bioconjugate Chem., 2018, 29, 2691-2700; (c) S. Liu and M. Han, Synthesis, Functionalization, and Bioconjugation of Monodisperse,
Silica-Coated Gold Nanoparticles: Robust Bioprobes, Adv. Funct. Mater., 2005, 15, 961-967.

15 X.-R. Jiang, P. Wang, C. L. Smith and B. T. Zhu, Synthesis of Novel Estrogen Receptor Antagonists Using Metal-Catalyzed Coupling Reactions and Characterization of Their Biological Activity, J. Med. Chem., 2013, 56, 2779-2790.

16 P. Dussault and A. Sahli, 2-Methoxy-2-propyl hydroperoxide: a convenient reagent for the synthesis of hydroperoxides and peracids, J. Org. Chem., 1992, 57, 1009-1012.

17 K. Rajender Reddy, M. Venkateshwar, C. Uma Maheswari and P. Santhosh Kumar, Mild and efficient oxy-iodination of alkynes and phenols with potassium iodide and tertbutyl hydroperoxide, Tetrahedron Lett., 2010, 51, 2170-2173.

18 (a) Y. Yamamoto, E. Niki and Y. Kamiya, Ozonization of Organic Compounds. Relative Reactivity of Protic Solvents Toward Carbonyl Oxide, Bull. Chem. Soc. Jpn., 1982, 55, 2405-2406; (b) T. Fisher and P. H. Dussault, Alkene Ozonolysis, Tetrahedron, 2017, 73, 4233-4258.

19 P. H. Dussault and D. R. Davies, Synthesis of 1,2-dioxanes, 1,2,4-trioxanes, and 1,2,4-trioxepanes via cyclizations of unsaturated hydroperoxyacetals, Tetrahedron Lett., 1996, 37, 463-466.

20 The $\mathrm{p} K_{\mathrm{a}}$ of propargyl alcohol is 13.2. Trifluoroethanol ( $\mathrm{p} K_{\mathrm{a}} \sim$ 12.4) has been employed as a nonnucleophilic polar solvent for ozonolysis: K. J. McCullough, H. Tokuhara, A. Masuyama and M. Nojima, New approaches to the synthesis of spiroperoxylactones, Org. Biomol. Chem., 2003, 1, 1522-1527.

21 Y. Hamada, H. Tokuhara, A. Masuyama, M. Nojima, H. S. Kim, K. Ono, N. Ogura and Y. Wataya, Synthesis and notable antimalarial activity of acyclic peroxides, 1(alkyldioxy)-1-(methyldioxy) cyclododecanes, J. Med. Chem., 2002, 45, 1374-1378.

22 L. Yao, B. T. Smith and J. Aubé, Base-Promoted Reactions of Bridged Ketones and 1,3- and 1,4-Haloalkyl Azides: Competitive Alkylation vs. Azidation Reactions of Ketone Enolates, J. Org. Chem., 2004, 69, 1720-1722.

23 (a) S. Isayama and T. Mukaiyama, A New Method for Preparation of Alcohols from Olefins with Molecular Oxygen and Phenylsilane by the use of Bis(acetylacetonato) cobalt(II), Chem. Lett., 1989, 18, 1071-1074; (b) T. Tokuyasu, S. Kunikawa, A. Masuyama and M. Nojima, Co(III)-alkyl complex- and Co(III)-alkylperoxo complexcatalyzed triethylsilylperoxidation of alkenes with molecular oxygen and triethylsilane, Org. Lett., 2002, 4, 3595-3598.

24 (a) Organic azides: syntheses and applications, ed. S. Bräse and K. Banert, John Wiley \& Sons, 2010; (b) T. M. Klapötke, T. Rotariu, B. Stiasny, J. Stierstorfer, S. Wiegmann and T. Zecheru, Azido (tert-butylperoxy) methyl Compounds-An Exceptional Class of Energetic Materials, Eur. J. Org. Chem., 2016, 4382-4386.

25 (a) F. Himo, T. Lovell, R. Hilgraf, V. V. Rostovtsev, L. Noodlesman, K. B. Sharpless and V. V. Fokin, Copper(I)Catalyzed Synthesis of Azoles. DFT Study Predicts Unprecedented Reactivity and Intermediates, J. Am. Chem. Soc., 2005, 127, 210-216; (b) P. Wu and V. V. Fokin, 
Catalytic Azide-Alkyne Cycloaddition: Reactivity and Applications, Aldrichimica Acta, 2007, 40, 7-17.

26 L. L. Smith and F. L. Hill, Detection of sterol hydroperoxides on thin-layer chromatoplates by means of the Würster dyes, J. Chromatogr., 1972, 66, 101-109.

27 (a) D. N. Barsoum, N. Okashah, X. Zhang and L. Zhu, Mechanism of Copper(I)-Catalyzed 5-Iodo-1,2,3-triazole Formation from Azide and Terminal Alkyne, J. Org. Chem., 2015, 80, 9542-9551; (b) D. N. Barsoum, C. J. Brassard, J. H. A. Deeb, N. Okashah, K. Sreenath, J. T. Simmons and L. Zhu, Synthesis of 5-Iodo-1,2,3-triazoles from organic azides and terminal alkynes: Ligand Acceleration Effect, Substrate Scope, and Mechanistic Insights, Synthesis, 2013, 45, 2372-2386; (c) J. E. Hein, J. C. Tripp, L. B. Krasnova, K. B. Sharpless and V. V. Fokin, Copper (I)-catalyzed cycloaddition of organic azides and 1-iodoalkynes, Angew. Chem., Int. Ed., 2009, 48, 8018-8021.

28 P. S. Donnelly, S. D. Zanatta, S. C. Zammit, J. M. White and S. J. Williams, "Click" cycloaddition catalysts: copper(i) and copper(ii) tris(triazolylmethyl)amine complexes, Chem. Commun., 2008, 2459.

29 (a) B. T. Worrell, J. A. Malik and V. V. Fokin, Direct Evidence of a Dinuclear Copper Intermediate in $\mathrm{Cu}(\mathrm{I})$-Catalyzed AzideAlkyne Cycloadditions, Science, 2013, 80(340), 457-460; (b) R. Berg and B. F. Straub, Advancements in the mechanistic understanding of the copper-catalyzed azide-alkyne cycloaddition, Beilstein J. Org. Chem., 2013, 9, 2715-2750.

30 B. H. Lipshutz, W. Chrisman and K. Noson, Hydrosilylation of aldehydes and ketones catalyzed by $\left[\mathrm{Ph}_{3} \mathrm{P}(\mathrm{CuH})\right]_{6}, J$. Organomet. Chem., 2001, 624, 367-371.

$31 \mathrm{~N}$. Kornblum and H. E. DeLaMare, The base catalyzed decomposition of a di-alkyl peroxide, J. Am. Chem. Soc., 1951, 73, 880-881.

32 (a) E. W. Elliott, A. L. Ginzburg, Z. C. Kennedy, Z. Feng and J. E. Hutchison, Single-Step Synthesis of Small, AzideFunctionalized Gold Nanoparticles: Versatile, WaterDispersible Reagents for Click Chemistry, Langmuir, 2017, 33, 5796-5802; (b) D. Baranov and E. N. Kadnikova, Synthesis and characterization of azidoalkyl-functionalized gold nanoparticles as scaffolds for "click"-chemistry derivatization, J. Mater. Chem., 2011, 21, 6152.

33 Y. Zhou, S. Wang, K. Zhang and X. Jiang, Visual Detection of Copper(II) by Azide- and Alkyne-Functionalized Gold Nanoparticles Using Click Chemistry, Angew. Chem., Int. Ed., 2008, 47, 7454-7456.

34 J. L. Brennan, N. S. Hatzakis, T. R. Tshikhudo, N. Dirvianskyte, V. Razumas, S. Patkar, J. Vind, A. Svendsen, R. J. M. Nolte, A. E. Rowan and M. Brust, Bionanoconjugation via Click Chemistry: The Creation of Functional Hybrids of Lipases and Gold Nanoparticles, Bioconjugate Chem., 2006, 17, 1373-1375.

35 V. Poonthiyil, T. K. Lindhorst, V. B. Golovko and A. J. Fairbanks, Recent applications of click chemistry for the functionalization of gold nanoparticles and their conversion to glyco-gold nanoparticles, Beilstein J. Org. Chem., 2018, 14, 11-24.
36 P. Zhao, M. Grillaud, L. Salmon, J. Ruiz and D. Astruc, Click Functionalization of Gold Nanoparticles Using the Very Efficient Catalyst Copper(I) (Hexabenzyl)tris(2-aminoethyl)amine Bromide, Adv. Synth. Catal., 2012, 354, 1001-1011.

37 E. Boisselier, L. Salmon, J. Ruiz and D. Astruc, How to very efficiently functionalize gold nanoparticles by "click" chemistry, Chem. Commun., 2008, 5788-5790.

38 (a) M. Brust, M. Walker, D. Bethell, D. J. Schiffrin and R. Whyman, Synthesis of Thiol-derivatised Gold Nanoparticles in a Two-phase Liquid-Liquid System, Chem. Commun., 1994, 801-802; (b) M. Brust, J. Fink, D. J. Schiffrina, D. Bethella and C. Kielyb, Synthesis and Reactions of Functionalised Gold Nanoparticle, Chem. Commun., 1995, 1655-1656.

39 Due to limited freedom of rotation, hydrogens near the Au-S interface are often invisible to solution phase NMR. (a) C. Guo and J. L. Yarger, Characterizing gold nanoparticles by NMR spectroscopy, Magn. Reson. Chem., 2018, 56, 10741082; (b) L. E. Marbella and J. E. Millstone, NMR Techniques for Noble Metal Nanoparticles, Chem. Mater., 2015, 27, 2721-2739.

40 Oxford Instruments, EDS in the TEM Explained (12 pages), 2013, https://nano.oxinst.com/product/eds-for-tem.

$41 \mathrm{X}$. Zhang, P. Liu and L. Zhu, Structural Determinants of Alkyne Reactivity in Copper-Catalyzed Azide-Alkyne Cycloadditions, Molecules, 2016, 21, 1-17.

42 A. Horn and P. H. Dussault, Synthesis of $\alpha$-cyano and $\alpha$ sulfonyl cyclic ethers via intramolecular reactions of peroxides with sulfone-and nitrile-stabilized carbanions, $J$. Org. Chem., 2019, 84, 14611-14626.

43 A. S. Olson, A. J. Jameson, S. K. Kyasa, B. W. Evans and P. H. Dussault, Reductive Cleavage of Organic Peroxides by Iron Salts and Thiols, ACS Omega, 2018, 3, 14054-14063.

44 X. Wang, Y. Dong, S. Wittlin, D. Creek, J. Chollet, S. A. Charman, J. Santo Tomas, C. Scheurer, C. Snyder and J. L. Vennerstrom, Spiro-and dispiro-1,2-dioxolanes: contribution of iron (II)-mediated one-electron vs. twoelectron reduction to the activity of antimalarial peroxides, J. Med. Chem., 2007, 50, 5840-5847.

45 D. A. Fleming, C. J. Thode and M. E. Williams, Triazole Cycloaddition as a General Route for Functionalization of Au Nanoparticles, Chem. Mater., 2006, 18, 2327-2334.

46 W. J. Sommer and M. Weck, Facile functionalization of gold nanoparticles via microwave-assisted 1,3 dipolar cycloaddition, Langmuir, 2007, 23, 11991-11995.

47 (a) W. Limapichat and A. Basu, Reagentless functionalization of gold nanoparticles via a $3+2$ Huisgen cycloaddition, J. Colloid Interface Sci., 2008, 318, 140-144; (b) C. J. Thode and M. E. Williams, Kinetics of 1,3-dipolar cycloaddition on the surfaces of $\mathrm{Au}$ nanoparticles, $J$. Colloid Interface Sci., 2008, 320, 346-352.

48 R. Cohen, Y. Mazuz, M. Tikhonov and C. M. Sukenik, Carboxylic Acid Decorated Self-Assembled Monolayer Films: New Acid Synthesis Chemistry and Reaction Chemistry Including Bridged Diacyl Peroxide Preparation, Langmuir, 2015, 31, 3049-3058. 
49 R. Mello and M. E. González Núñez, Reactions of Peroxides on Solid Surfaces, in PATAI'S Chemistry of Functional Groups, ed. Z. Rappoport, DOI: 10.1002/ 9780470682531.pat0880.

50 K. L. Norrod and K. L. Rowlen, Ozone-induced oxidation of self-assembled decanethiol: contributing mechanism for "photooxidation"?, J. Am. Chem. Soc., 1998, 120(11), 26562657.

51 (a) W. Liu, X. Liu, D. Knaebel, L. Luck and Y. Li, Synthesis and antibacterial evaluation of novel water-soluble organic peroxides, Antimicrob. Agents Chemother., 1998, 42, 911915; (b) C. G. Burkhart and C. N. Burkhart, Antibacterial properties of soluble benzoyl peroxide, Int. J. Dermatol., 2008, 47, 301-302.

52 For an example of surface-specific peroxide chemistry involving an adsorbed peroxide, see: N. Walalawela and A. Greer, Heterogeneous photocatalytic deperoxidation with UV and visible light, J. Phys. Org. Chem., 2018, 31, e3807.

$53 \mathrm{~K}$. Tokumaru, Complications in photochemistry of organic peroxides, Res. Chem. Intermed., 1996, 22, 255-273.

54 (a) R. Willand-Charnley, B. W. Puffer and P. H. Dussault, Oxacycle synthesis via intramolecular reaction of carbanions and peroxides, J. Am. Chem. Soc., 2014, 136, 5821-5823; (b) L. Lemee, M.-J. Bourgeois and E. Montaudon, Decomposition induced by acetylenic peroxides, Bull. Soc. Chim. Belg., 1996, 105, 467-472.

55 M. T. Wlodarczyk, S. A. Dragulska, O. Camacho-Vanegas, P. R. Dottino, A. A. Jarzęcki, J. A. Martignetti and A. J. Mieszawska, Platinum (II) complex-nuclear localization sequence peptide hybrid for overcoming platinum resistance in cancer therapy, ACS Biomater. Sci. Eng., 2018, 4, 463-467.

56 (a) J. N. Eildal, A. Bach, J. Dogan, F. Ye, M. Zhang, P. Jemth and K. Strømgaard, Rigidified Clicked Dimeric Ligands for Studying the Dynamics of the PDZ1-2 Supramodule of PSD-95, ChemBioChem, 2015, 16, 64-69; (b) A. Krasiński, Z. Radic,, R. Manetsch, J. Raushel, P. Taylor, K. B. Sharpless and H. C. Kolb, In situ selection of lead compounds by click chemistry: target-guided optimization of acetylcholinesterase inhibitors, J. Am. Chem. Soc., 2005, 127, 6686-6692.

57 P. H. Dussault, I. Q. Lee, H. J. Lee, R. J. Lee, Q. J. Niu, J. A. Schultz and U. R. Zope, Peroxycarbenium-mediated C$\mathrm{C}$ bond formation: applications to the synthesis of hydroperoxides and peroxides, J. Org. Chem., 2000, 65, 8407-8414.

58 J. E. Baldwin, L. Bischoff, T. D. W. Claridge, F. A. Heupel, D. R. Spring and R. C. Whitehead, An approach to the manzamine alkaloids modelled on a biogenetic theory, Tetrahedron, 1997, 53, 2271-2290.
59 R. J. Armstrong, W. Niwetmarin and V. K. Aggarwal, Synthesis of Functionalized Alkenes by a Transition-MetalFree Zweifel Coupling, Org. Lett., 2017, 19, 2762-2765.

$60 \mathrm{~J}$. van der Louw, J. L. van der Baan, F. J. de Kanter, F. Bickelhaupt and G. W. Klumpp, Allylmetallation of 1silylalkynes by 2-(bromozincmethyl)-2-alkenyl ethers followed by Pd (0)-catalyzed cyclization: a one-pot synthesis of 4-methylenecyclopentenes, Tetrahedron, 1992, 48, 60876104.

61 B. R. Brutiu, W. A. Bubeneck, O. Cvetkovic, J. Li and N. Maulide, On the formation of seven-membered rings by arene-ynamide cyclization, Monatsh. Chem., 2019, 150, 3-10.

$62 \mathrm{M}$. Schmittel and C. Vavilala, Kinetic isotope effects in the thermal $\mathrm{C}_{2}-\mathrm{C}_{6}$ cyclization of enyne-allenes: experimental evidence supports a stepwise mechanism, J. Org. Chem., 2005, 70, 4865-4868.

63 J. M. Smith, T. Qin, R. R. Merchant, J. T. Edwards, L. R. Malins, Z. Liu, G. Che, Z. Shen, S. A. Shaw, M. D. Eastgate and P. S. Baran, Decarboxylative Alkynylation, Angew. Chem., Int. Ed., 2017, 56, 11906-11910.

64 J. Maury, L. Feray, M. P. Bertrand, A. Kapat and P. Renaud, Unexpected conversion of alkyl azides to alkyl iodides and of aryl azides to N-tert-butyl anilines, Tetrahedron, 2012, 68, 9606-9611.

65 S. M. Smith and J. M. Takacs, Amide-Directed Catalytic Asymmetric Hydroboration of Trisubstituted Alkenes, J. Am. Chem. Soc., 2010, 132, 1740-1741.

66 T. Suzuki, Y. Ota, Y. Kasuya, M. Mutsuga, Y. Kawamura, H. Tsumoto, H. Nakagawa, M. G. Finn and N. Miyata, An unexpected example of protein-templated click chemistry, Angew. Chem., Int. Ed., 2010, 49, 6817-6820.

67 K. Motesharei and D. C. Myles, Molecular Recognition on Functionalized Self-Assembled Monolayers of Alkanethiols on Gold, J. Am. Chem. Soc., 1998, 120, 7328-7336.

68 M. H. Keylor, J. E. Park, C. J. Wallentin and C. R. J. Stephenson, Photocatalytic initiation of thiol-ene reactions: synthesis of thiomorpholin-3-ones, Tetrahedron, 2014, 70, 4264-4269.

69 C. Ligeour, A. Meyer, J. J. Vasseur and F. Morvan, Bis- and Tris-Alkyne Phosphoramidites for Multiple 5'-Labeling of Oligonucleotides by Click Chemistry, Eur. J. Org. Chem., 2012, 1851-1856.

70 F. Gonzàlez De Rivera, I. Angurell, O. Rossell, M. Seco and J. Llorca, Organometallic surface functionalization of gold nanoparticles, J. Organomet. Chem., 2012, 715, 13-18.

71 W. Haiss, N. T. K. Thanh, J. Aveyard and D. G. Fernig, Determination of Size and Concentration of Gold Nanoparticles from UV-Vis Spectra, Anal. Chem., 2007, 79, 4215-4221. 